ESTUDO MORFOMÉTRICO DA AUTÓLISE ACINAR EM GLÂNDULAS

SUBLINGUAIS DE RATOS: SUA RELAÇÃO COM INTERVALO POST

MORTEM E O VOLUME DO FIXADOR

Letícia Rodrigues $\mathcal{N}$ ery

Dissertação apresentada à Faculdade de Odontologia de Bauru, da Universidade de São Paulo, como parte dos requisitos para obtenção do título de Mestre em Odontologia, área de Estomatologia.

Orientador: Prof. Dr. José Humberto Damante

\title{
BAURU
}




\section{ESTUDO MORFOMÉTRICO DA AUTÓLISE ACINAR EM \\ GLÂNDULAS SUBLINGUAIS DE RATOS: SUA RELAÇÃO COM INTERVALO POST MORTEM E O VOLUME DO FIXADOR}

Letícia Rodrigues $\mathcal{N e r y}$

Dissertação apresentada à Faculdade
de Odontologia de Bauru, da
Universidade de São Paulo, como parte
dos requisitos para obtenção do título
de Mestre em Odontologia, área de
Estomatologia.

Orientador: Prof. Dr. José Humberto Damante

\section{BAURU}




\section{Nery, Letícia Rodrigues}

N 359e Estudo morfométrico da autólise acinar em glândulas sublinguais de ratos: sua relação com intervalo post mortem e o volume de fixador /Letícia Rodrigues Nery - Bauru, 2007.

137p; il.; $30 \mathrm{~cm}$

Dissertação (Mestrado) - Faculdade de Odontologia de Bauru. USP.

Orientador: Prof. Dr. José Humberto Damante

Autorizo, exclusivamente para fins acadêmicos e científicos, a reprodução total ou parcial desta dissertação, por processos fotocopiadores e/ou meios eletrônicos.

Assinatura do autor:

Data: / 2007.

Comitê de Ética em Pesquisa da FOB

No. do Protocolo: 09/2005

Data: 13 de junho de 2005. 


\section{LetícIa RodRIgues NeRY}

\begin{tabular}{l|l}
$\begin{array}{l}\text { Jundiaí - SP de julho de } 1980 \\
\text { Filiação }\end{array}$ & $\begin{array}{l}\text { Nascimento } \\
\text { Antonio Carlos Nery } \\
\text { Ana Cecília Rodrigues Nery } \\
1999-2002\end{array}$ \\
2003 & $\begin{array}{l}\text { Curso de Odontología - Centro Universitário Hermínio } \\
\text { Ometto - UNIARARAS } \\
\text { Curso de Aperfeiçoamento em Odontopediatria - Centro } \\
\text { Universitário Hermínio Ometto - UNIARARAS } \\
\text { Estágio em Clínica Integrada - Área de Semiologia - } \\
\text { Centro Universitário Hermínio Ometto - UNIARARAS } \\
\text { Curso de Pós-Graduação em Estomatologia em nível de } \\
\text { Mestrado - Faculdade de Odontologia de Bauru - USP }\end{array}$
\end{tabular}




\section{Dedico este trabalho}

Ao meu bem Leandro, que suportou o peso da distância e as barreiras da saudade, entendeu os momentos de ausência, pela compreensão, apoio, amor e incentivo durante toda esta trajetória, por sempre saber usar as melhores palavras nas horas mais certas, não me deixando nunca desanimar, e principalmente, por ser a pessoa maravilhosa que amo, admiro e tenho a sorte de ter ao meu lado. Te amo mais que tudo!!

Aos meus pais Antonio e Cecília, pelo exemplo de vida e pelo apoio incondicional a mim dedicado. Por estarem sempre presentes, mesmo que só em mente e coração.

À Daniele, mais que uma amiga, pelo apoio e amizade, sempre compartilhando todos os momentos da minha vida e torcendo para que tudo dê certo.

Aos meus irmãos Bruno, Caio e Beatriz, que aprenderam a me acompanhar sempre de longe, torcendo para que eu alcançasse sempre meus objetivos. 


\section{Agradecimentos especias}

Ao Professor Doutor José Humberto Damante, exemplo a ser

seguido como pessoa e profissional, pela orientação, atenção, dedicação, incentivo, competência e acima de tudo amizade, sem os

quais não seria possível a realização deste trabalho. Meu eterno carinho, respeito, admiração e gratidão.

À minha "mãe" Carla Ruffeil Moreira, muito obrigada pela paciência, dedicação e pelas conversas em todas as horas necessárias ou não, sempre incentivando a realização deste trabalho.

À técnica do laboratório de histologia e doutoranda Tânia Cestari, pessoa de fundamental importância para o andamento desta pesquisa. Todo seu amor à pesquisa é um exemplo de dedicação ao trabalho. Obrigada pelos ensinamentos transmitidos, estando sempre disponível, apesar de super atarefada, nos momentos de dúvidas. 


\section{Agradecimentos}

Aे Deus,

Pela oportunidade de viver para aprimorar o meu espírito e por todas as bênçãos que me tem concedido.

À Faculdade de Odontologia de Bauru,

Na pessoa de seu diretor, Prof. Dr. Luiz Fernando Pegoraro.

À Comissão de Pós-graduação,

$\mathrm{Na}$ pessoa de seu coordenador, Profa. Dra. Maria Aparecida de Andrade Moreira Machado.

À Fundação de Amparo à Pesquisa do Estado de São Paulo - FAPESP,

Pelo investimento através da bolsa de mestrado (05/53340-7).

Aos professores e funcionários do Departamento de Estomatologia (Disciplinas de Radiologia, Estomatologia e Cirurgia),

Profa. Dra. Ana Lúcia Álvares Capelozza, Prof. Dr. Eduardo Sant'Ana, Profa. Dra. Izabel Regina Fischer Rubira-Bullen, Prof. Dr. Luiz Eduardo Montenegro Chinellato, Prof. Dr. Osny Ferreira Júnior, Prof. Dr. Paulo Perri, Antônio Roque dos Santos, Camila Medina, Elza Cassalate, Fernanda Cavalari, Hebe Pereira, Josieli Farinha, Luciana Zanon, Marília Gião, Patrícia Germino, Reinaldo Vieira, Roberto Sales, pelos ensinamentos na clínica e amizade sincera. 
Aos professores e funcionários do Departamento de Ciências Biológicas (Disciplina de Histologia),

Prof. Dr. Rumio Taga, Prof. Dr. Gerson Francisco de Assis, Prof. Dr. Gustavo Pompermaier Garlet, Aldivina da Silva, Bruno Viscelli, Daniele Ceolin, Isabel Meneghetti, Juliana Oliveira, Tânia Cestari, Beonildes Terezinha Ruiz pela disposição em ajudar e pela alegria do convívio.

Aos professores e funcionários do Departamento de Estomatologia (Disciplina de Patologia),

Prof. Dr. Alberto Consolaro, Prof. Dr. Antônio Taveira, Profa. Dra. Denise Oliveira, Profa. Dra. Vanessa Lara, Maria Cristina Felipe, Fátima Silveira, Valdir João Afonso.

Ao professor do Departamento de Saúde Coletiva (Disciplina de Estatística), Na pessoa do Prof. Dr. José Roberto Lauris.

Ao professor do Departamento de Ciências Biológicas (Disciplina de Fisiologia/Farmacologia),

Na pessoa do Prof. Dr. Carlos Ferreira dos Santos.

Aos amigos do curso de Pós-graduação (mestrado),

Danielle Albuquerque, Gustavo Lautenschläger, Marta Lima, Moacyr Tadeu Rodrigues e Renata Teixeira pelos momentos agradáveis passados juntos.

Aos colegas do curso de Pós-graduação (doutorado),

Carla Moreira, Cássia Rubira, Cláudio Xavier, Eduardo Gonçales, Etiene Munhoz, Fernando Giglio, Flávio Amado, Josiane de Sá, Luís Fernando Sant'Ana, Marcelo Zanda, Melissa Araújo, Renato Yaedú. 
À todos os demais funcionários da Faculdade de Odontologia de Bauru.

Aos professores do Centro Universitário Hermíno Ometto, UNIARARAS,

Prof. Dr. Sérgio Kignel e Profa. Florence Mistro, pelo incentivo constante.

Aos amigos

Carla Moreira, Etiene Munhoz, Kizze Lima, Luciana Rosa, pela convivência diária.

Daniela Moreno, Elaine Andrade, Juliana Gomes, Letícia Mendes, Luciana Steiner, Maria Virginia Denardi, Patrícia Lopes e Tatiane Andrade que, apesar da distância, se fazem sempre presentes...

Augusto Bodanezi, Camila Cardoso, Gabriel Bernini, Gustavo Lautenschläger, Marcelo Zanda, Moacyr Tadeu Rodrigues, Thais Fernandes pela amizade e momentos de descontração.

Aos familiares

Meus avós, Dr. Moreno, Dona Rosa e Dona Lazinha, à todos os tios, meus sogros, Oswaldo e Zulmira, meus cunhados, Daniela, Jossimara, Leonardo e Marcelo, e à todos que, direta ou indiretamente, contribuíram para a realização deste trabalho.

Muito obrigado a todos, por participarem desta etapa tão importante da minha vida! 


\section{SUMÁRIO}

LISTA DE FIGURAS.....................................................................

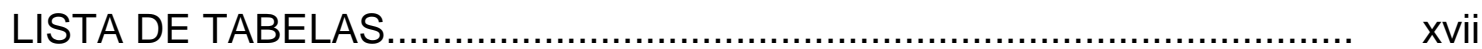

RESUMO

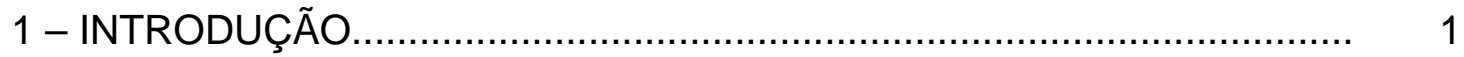

2 - REVISÃO DE LITERATURA.................................................... 5

2.1 Anatomia e histologia das glândulas sublinguais de ratos.................... 7

2.2 Estudos relacionados à fixação e artefatos......................................... 8

2.3 Estudos relacionados à autólise ..................................................... 11

3 - PROPOSIÇÃO ...................................................................... 17

4 - MATERIAL E MÉTODOS..................................................... 21

4.1 Sacrifício dos animais............................................................ 25

4.2 Procedimentos histológicos........................................................ 29

4.3 Determinação do volume processado................................................ $\quad 29$

4.3.1 Avaliação da densidade da glândula.............................................. 31

4.3.2 Determinação da retração provocada pelo processamento histológico 31

4.4 Estudo Morfométrico................................................................. 32

4.4.1 Casualização dos campos histológicos............................................. 32

4.4.2 Sistema-teste utilizado nas avaliações morfométricas........................ 33

4.4.3 Determinação da densidade de volume (Vvi) dos ácinos íntegros e autolisados.

4.4.4 Determinação do volume absoluto (Vt) dos ácinos íntegros e autolisados.

4.4.5 Determinação do coeficiente de variação da média ("erro")............... 35

4.4.6 Critérios adotados nas quantificações......................................... 37

4.5 Tratamento estatístico dos dados........................................................ 43

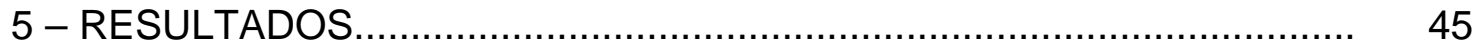

$\begin{array}{ll}5.1 \text { Resultados quantitativos } & 47\end{array}$

PARTE A: Estudo da evolução do processo de autólise nos diferentes períodos post mortem. 


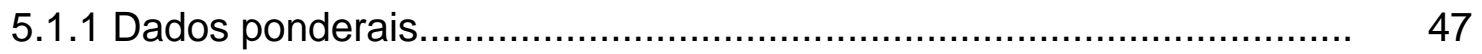

5.1.1.1 Dados ponderais de massa corporal........................................... 4

5.1.1.2 Dados ponderais de massa glandular............................................. 49

5.1.1.3 Densidade glandular............................................................... 51

5.1.1.4 Fator de retração.................................................................. 53

5.1.1.5 Volume processado............................................................ 5

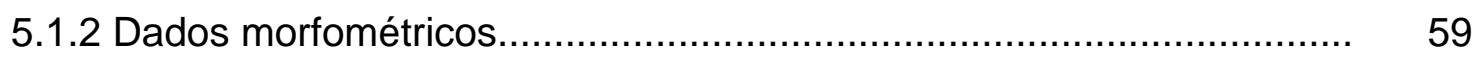

5.1.2.1 Densidade de volume (Vvi) de ácinos íntegros e autolisados........... $\quad 59$

5.1.2.2 Volume absoluto (Vt) de ácinos íntegros e autolisados.................... 61

5.1.2.3 Cálculo do coeficiente de variação ("erro")....................................... 65

PARTE B: Estudo da Interferência do volume de fixador no processo de

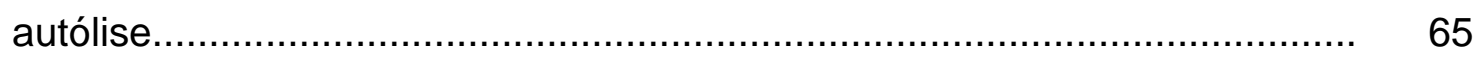

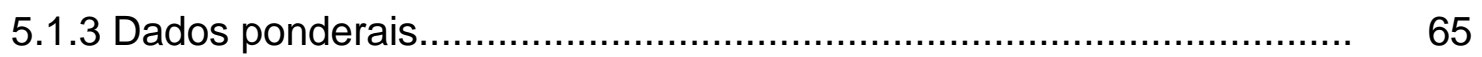

5.1.3.1 Dados ponderais de massa corporal............................................ 65

5.1.3.2 Dados ponderais de massa glandular............................................ 67

5.1.3.3 Densidade glandular................................................................

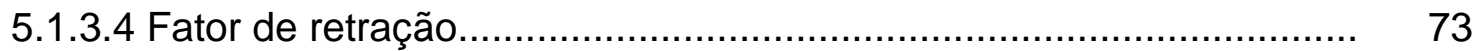

5.1.3.5 Volume processado................................................................. $\quad 75$

5.1.4 Dados morfométricos............................................................ $\quad 77$

5.1.4.1 Densidade de volume (Vvi) de ácinos íntegros e autolisados........... 77

5.1.4.2 Volume absoluto (Vt) de ácinos íntegros e autolisados..................... 79

5.1.4.3 Cálculo do coeficiente de variação ("erro")...................................... 79

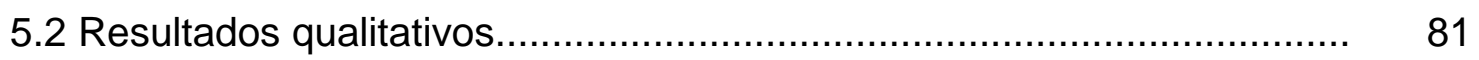

PARTE A: Estudo da evolução do processo de autólise nos diferentes períodos post mortem.

PARTE B: Estudo da Interferência do volume de fixador no processo de autólise.

6 - DISCUSSÃO

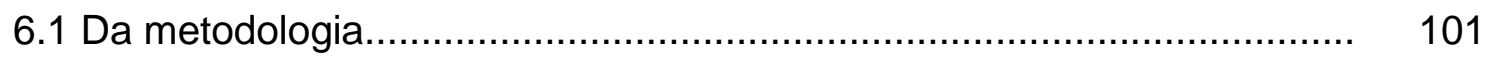

6.1.1 Da casualização dos campos histológicos........................................... 102

6.1.2 Dos critérios para gradação da autólise............................................. 102 
6.2 Dos resultados.

6.2.1 Dos resultados quantitativos.

PARTE A: Estudo da evolução do processo de autólise nos diferentes períodos post mortem

6.2.1.1 Da massa corporal e glandular.

6.2.1.2 Da densidade, fator de retração e volume processado da glândula..

104

6.2.1.3 Da densidade de volume 104

6.2.1.4 Do volume absoluto...... 105

PARTE B: Estudo da Interferência do volume de fixador no processo de autólise. 106

6.2.1.5 Da massa corporal e glandular. 106

6.2.1.6 Da densidade, fator de retração e volume processado da glândula.. 106

6.2.1.7 Da densidade de volume e volume absoluto. 107

6.2.2 Dos resultados qualitativos.

PARTE A: Estudo da evolução do processo de autólise nos diferentes períodos post mortem

PARTE B: Estudo da Interferência do volume de fixador no processo de autólise.

7- CONCLUSÕES.

ANEXOS 


\section{Lista de Figuras}

FIGURA 1. Esquema de distribuição dos animais para os diferentes ensaios da pesquisa.

FIGURA 2. a) Solução de atropina e b) Medicamentos usados para obtenção do sacrifício dos animais.

FIGURA 3. Seqüência da dissecação das glândulas sublinguais. a) rebatimento da pele na região ventral do pescoço; b) localização das glândulas sublingual (apontada) e submandibular; c) localização da glândula parótida; d) glândulas sublinguais (1), submandibulares (2) e as parótidas (3)

FIGURA 4. Determinação da densidade da glândula: a) balança Mettler Toledo AT261 Delta Rang, contendo conjunto de acessórios Metler AT/AG e PG/PG-S/PR para determinação da densidade de sólidos; b) determinação da massa fresca glandular (m); e c) determinação do volume de água deslocado (v)

FIGURA 5. Esquema de casualização dos 10 campos microscópicos por corte histológico.

FIGURA 6. Determinação da densidade de volume de cada estrutura pela contagem de pontos. Esquema ilustrativo.

FIGURA 7. Ácinos mucosos(*) e mistos(setas) íntegros (HE aumento de $384 \times 0 h / 20 \mathrm{ml})$.

FIGURA 8. Ácinos mistos e mucosos $(*)$ em estágio inicial de autólise (HE aumento de $384 \times 12 \mathrm{~h} / 20 \mathrm{ml}$ ).

FIGURA 9. Ácinos mistos e mucosos em estágio intermediário de autólise (HE aumento de 384x 12h/20ml).....

FIGURA 10. Ácinos em estágio final de autólise (HE aumento de 384x $12 \mathrm{~h} / 2 \mathrm{ml})$.

FIGURA 11. Estruturas quantificadas como outras, ductos (*), septo (seta) e artefato de técnica $(\diamond)$ (HE aumento de 96x 12h/2ml).

FIGURA 12. Distribuição das médias e desvios padrão da massa corporal 
(g) dos animais do Grupo I, nos diferentes períodos post mortem.

FIGURA 13. Distribuição das médias e desvios padrão da massa glandular (mg) das sublinguais dos animais do Grupo I, nos diferentes períodos post mortem.

FIGURA 14. Distribuição das médias e desvios padrão da densidade das glândulas sublinguais $\left(\mathrm{mg} / \mathrm{cm}^{3}\right)$ dos animais do Grupo II, nos diferentes períodos post mortem.

FIGURA 15. Distribuição das médias e desvios padrão do fator de retração das glândulas sublinguais dos animais do Grupo II, nos diferentes períodos post mortem.

FIGURA 16. Distribuição da média e desvio padrão (DPM) do volume processado $\left(\mathrm{mm}^{3}\right)$ das glândulas sublinguais dos animais do Grupo II, nos diferentes períodos post mortem

FIGURA 17. Distribuição das médias da densidade de volume de ácinos íntegros e autolisados dos animais do Grupo I, nos diferentes períodos post mortem.

FIGURA 18. Distribuição das médias do volume absoluto de ácinos íntegros e autolisados dos animais do Grupo I, nos diferentes períodos post mortem.

FIGURA 19. Distribuição das médias e desvios padrão da massa corporal (g) dos animais dos grupos onde houve variação de volume do líquido fixador.

FIGURA 20. Distribuição das médias e desvios padrão da massa glandular (mg) da sublingual dos animais dos grupos onde houve variação de volume do líquido fixador.

FIGURA 21. Distribuição das médias e desvios padrão da densidade das glândulas sublinguais $\left(\mathrm{mg} / \mathrm{cm}^{3}\right)$ dos animais dos grupos onde houve variação de volume do líquido fixador.

FIGURA 22. Distribuição das médias e desvios padrão do fator de retração das glândulas sublinguais dos animais dos grupos onde houve variação de 
volume do líquido fixador.

FIGURA 23. Distribuição das médias e desvios padrão do volume processado $\left(\mathrm{mm}^{3}\right)$ das glândulas sublinguais dos animais dos grupos onde houve variação de volume do líquido fixador.

FIGURA 24. Fotomicrografia da glândula sublingual coletada as 0 hora: a) aspecto panorâmico, observar a integridade da estrutura glandular, exibindo ácinos mistos com células mucosas $(\mathrm{M})$ volumosas e pequenas semiluas serosas (seta cheia) e ductos intralobulares (D) entremeados pelo estroma (seta vermelha). HE

FIGURA 25. Fotomicrografia da glândula sublingual coletada as 0 hora: detalhe dos ácinos mistos exibindo células mucosas bem delimitadas com citoplasma abundante e núcleo elíptico, ocupando a porção supra basal da célula e semiluas serosas (seta cheia) com células serosas contendo pouco citoplasma e núcleo elíptico, ocupando a porção central da célula. HE.

FIGURA 26. Fotomicrografia da glândula sublingual coletada às 3 horas: aspecto panorâmico, observar a aparente integridade da estrutura glandular, exibindo ácinos mistos com células mucosas (M) volumosas e pequenas semiluas serosas (seta cheia) e ductos intralobulares (D) entremeados pelo estroma (seta vermelha). HE.

FIGURA 27. Fotomicrografia da glândula sublingual coletada às 3 horas: detalhe dos ácinos mistos exibindo algumas células mucosas (M) com perda da integridade do seu limite externo e células serosas íntegras. HE.

FIGURA 28. Fotomicrografia da glândula sublingual coletada às 6 horas: aspecto panorâmico, observar a desorganização da estrutura glandular, exibindo ácinos mistos com células mucosas (M) volumosas com borramento do limite externo e pequenas semi-luas serosas (seta preta) e ductos intralobulares em necrose avançada (D) entremeados pelo estroma (seta vermelha). HE.

FIGURA 29. Fotomicrografia da glândula sublingual coletada às 6 horas: 
detalhe dos ácinos mistos exibindo algumas células mucosas (M) com perda da integridade do seu limite externo (seta azul) e cariorrexe (círculo) e células serosas (seta preta). HE.

FIGURA 30. Fotomicrografia da glândula sublingual coletada às 12 horas: aspecto panorâmico, observar a desorganização da estrutura glandular, exibindo ácinos mistos com células mucosas (M) volumosas com borramento do seu limite externo e pequenas semi-luas serosas (seta preta) e ductos intralobulares em necrose (D) entremeados pelo estroma (seta vermelha). HE.

FIGURA 31. Fotomicrografia da glândula sublingual coletada às 12 horas: detalhe dos ácinos mistos exibindo células mucosas (M) com perda da integridade do seu limite externo (seta azul) e cariorrexe (círculo) e picnose (cabeça de seta) e células serosas (seta preta) com cariorrexe. HE.

FIGURA 32. Fotomicrografia da glândula sublingual coletada às 12 horas: aspecto panorâmico, observar maior desorganização da estrutura glandular em relação a figura anterior, exibindo ácinos mistos com células mucosas (M) volumosas com borramento do seu limite externo e pequenas semi-luas serosas (seta preta) e ductos intralobulares em necrose (D) entremeados pelo estroma (seta vermelha). HE.

FIGURA 33. Fotomicrografia da glândula sublingual coletada às 12 horas: detalhe dos ácinos mistos exibindo células mucosas ( $M$ ) com perda da sua integridade externa (seta azul) e outros com total desintegração do limite externo (asterisco) e picnose (cabeça de seta) e células serosas (seta preta) com cariorrexe (círculo). HE.

FIGURA 34. Fotomicrografia da glândula sublingual coletada às 24 horas: aspecto panorâmico, observar desorganização da estrutura glandular em relação a figura anterior, exibindo ácinos mistos com células mucosas (M), apresentando borramento do limite externo e pequenas semi-luas serosas (seta preta) entremeados pelo estroma (seta vermelha) pouco visível. ME....... 
FIGURA 35. Fotomicrografia da glândula sublingual coletada às 24 horas: detalhe dos ácinos mistos ainda delimitados (seta amarela), exibindo células mucosas ( $M$ ) com perda total desintegração do limite externo (asterisco), cariorrexe (círculo) e picnose (cabeça de seta) e células serosas (seta preta) com núcleo picnótico. HE.

FIGURA 36. Fotomicrografia da glândula sublingual coletada às 24 horas: aspecto panorâmico, observar completa desorganização das estruturas glandulares, exibindo rompimento dos ácinos e extravasamento do conteúdo celular dificultando a visualização do estroma (seta vermelha). $\mathrm{HE}$

FIGURA 37. Fotomicrografia da glândula sublingual coletada às 24 horas: detalhe dos ácinos com rompimento de membrana (seta amarela) e completa desorganização do conteúdo celular e células serosas (seta preta) íntegras, dispersos no interior da massa amorfa oriunda da destruição das células mucosas. HE 


\section{Lista de $T_{\text {ABelas }}$}

TABELA 1. Médias e desvios padrão da massa corporal (g) dos animais do Grupo I, nos diferentes períodos post mortem.

TABELA 2. Médias e desvios padrão da massa glandular (mg) das sublinguais dos animais do Grupo I, nos diferentes períodos post mortem.

TABELA 3. Médias e desvios padrão da densidade glandular $\left(\mathrm{mg} / \mathrm{cm}^{3}\right)$ das sublinguais dos animais do Grupo II, nos diferentes períodos post mortem.

TABELA 4. Médias e desvios padrão do fator de retração das glândulas sublinguais dos animais do Grupo II, nos diferentes períodos post mortem.

TABELA 5. Médias e desvios padrão do volume processado $\left(\mathrm{mm}^{3}\right)$ das glândulas sublinguais dos animais do Grupo II, nos diferentes períodos post mortem.

TABELA 6. Médias da densidade de volume de ácinos íntegros e autolisados dos animais do Grupo I, nos diferentes períodos post mortem.

TABELA 7. Médias do volume absoluto de ácinos íntegros e autolisados dos animais do Grupo I, nos diferentes períodos post mortem

TABELA 8. Coeficiente de variação médio para os ácinos íntegros e autolisados no Grupo I, nos diferentes períodos post mortem

TABELA 9. Médias e desvios padrão da massa corporal (g) dos animais dos grupos onde houve variação de volume do líquido fixador.

TABELA 10. Médias e desvios padrão da massa glandular (mg) da sublingual dos animais dos grupos onde houve variação de volume do líquido fixador.

TABELA 11. Médias e desvios padrão da densidade glandular $\left(\mathrm{mg} / \mathrm{cm}^{3}\right)$ das sublinguais dos animais dos grupos onde houve variação de volume do líquido fixador 
TABELA 12. Médias e desvios padrão do fator de retração das glândulas sublinguais dos animais dos grupos onde houve variação de volume do líquido fixador.

TABELA 13. Médias e desvios padrão do volume processado $\left(\mathrm{mm}^{3}\right)$ das glândulas sublinguais dos animais dos grupos onde houve variação de volume do líquido fixador.

TABELA 14. Médias da densidade de volume de ácinos íntegros e autolisados nos grupos estudados que variam na quantidade de líquido fixador

TABELA 15. Médias do volume absoluto de ácinos íntegros e autolisados dos animais dos grupos estudados que variam na quantidade de líquido fixador.

TABELA 16. Coeficiente médio de variação dos ácinos íntegros e autolisados no grupo utilizado para avaliar a variação de volume de formol. 
RESUMO 


\section{ResUmO}

A autólise acinar post mortem em glândulas sublinguais humanas é um fenômeno que prejudica a sua análise microscópica. Com o objetivo de esclarecer e prevenir tal ocorrência, a presente investigação foi planejada no sentido de analisar morfometricamente as possíveis influências do intervalo post mortem (IPM) e do volume de fixador histológico (VF) na ocorrência de autólise de ácinos em glândulas sublinguais de ratos. Dos sessenta animais utilizados na investigação, cinqüenta deles o foram no estudo do intervalo post mortem, sendo divididos em 2 grupos: o grupo I (25 animais) foi destinado para as avaliações morfométricas e o grupo II (25 animais) para determinação do fator de retração e densidade da glândula. Os grupos I e II foram subdivididos nos subgrupos: A e A1 (controle - 0 hora), B e B1 (3 horas post mortem), C e C1 (6 horas), D e D1 (12 horas) e E e E1 (24 horas), com 5 animais em cada um. A fixação foi realizada com $20 \mathrm{~mL}$ de solução de formol a 10\% em tampão fosfato. Os 10 animais remanescentes foram destinados ao estudo da variação de volume do fixador, e foram divididos em 2 grupos iguais: no grupo $2 \mathrm{~mL}$, as glândulas dos 5 animais foram fixadas com $2 \mathrm{~mL}$ de solução de formol a 10\% tamponada, e no grupo $20 \mathrm{~mL}$, as glândulas dos outros 5 animais foram fixadas com $20 \mathrm{~mL}$ da mesma solução. O tempo de fixação foi de 7 dias para todos. As glândulas foram processadas histologicamente, sendo os cortes histológicos corados com H.E. A análise morfométrica foi realizada em 50 campos histológicos por glândula, selecionados por amostragem sistemática, usando objetiva de 100x e ocular Kpl 8x contendo um retículo de integração constituído por 100 pontos simetricamente distribuídos. A densidade de volume dos ácinos íntegros e autolisados foi avaliada pelo método morfométrico de volumetria relativa de contagem de pontos. Houve diferença estatisticamente significante entre o IPM e a autólise acinar $(p<0,05)$, enquanto que não houve diferença significante quanto ao VF $(p=0,690)$. A autólise acinar aumentou significantemente com o aumento do período post mortem $(p<0,05)$. Baseado nos resultados obtidos foi possível concluir que a 
autólise acinar em glândulas sublinguais de ratos está diretamente relacionada ao intervalo post mortem, não sendo influenciada pelo volume de fixador histológico testado no experimento.

Palavras chave: glândula sublingual, autólise, fixação de tecidos 


\section{1 - INTRODUÇÃO}

A autólise post mortem é a destruição espontânea de células ou tecidos por enzimas hidrolíticas da própria célula (SHIMIZU et al. $\left.{ }^{1}, 1990\right)$, muitas destas lisossomais (GUIMARÃES², 1982). A velocidade do processo autolítico varia consideravelmente com a temperatura, o tipo de tecido e o teor de enzimas hidrolíticas (GUIMARÃES $\left.{ }^{2}, 1982\right)$.

O intervalo post mortem é o fator que mais influencia na autólise: quanto mais longo o tempo de óbito, maior a intensidade do fenômeno. Por outro lado, no infarto agudo do miocárdio as primeiras evidências histológicas de necrose manifestam-se 4 a 12 horas mais tarde (KUMAR; ABBAS; FAUSTO ${ }^{3}$, 1999). O modo do óbito também pode influenciar o processo de autólise, ou seja, a morte de causa aguda daria autólise severa enquanto a de causa crônica daria autólise moderada. Além do modo do óbito e do intervalo post mortem, outros fatores como a temperatura do corpo no momento do óbito e a hora do óbito podem influenciar a autólise (SHIMIZU et al. $\left.{ }^{1}, 1990\right)$.

A refrigeração retarda a autólise por reduzir a atividade das enzimas hidrolíticas e o crescimento das bactérias (GUIMARÃES ${ }^{2}$, 1982). A catepsina, uma proteinase intracelular encontrada em muitos tecidos animais e abundante no fígado, rim e baço, é uma das enzimas mais importantes no processo autolítico. Admite-se nos óbitos por processos crônicos, que a atividade enzimática seria menor que nos óbitos por processos agudos. Nestes a autólise seria moderada (SHIMIZU et al. ${ }^{1}$, 1990). A fixação dos tecidos com formalina, formol a $10 \%$, provoca a inativação enzimática, impedindo a autólise celular. Desta forma, o objetivo de uma solução fixadora, no caso de tecidos vivos, é matar a célula conservando suas estruturas com as características que tinham em vida. Deve-se fixar o material imediatamente após a remoção, para evitar o ressecamento da peça e os efeitos da autólise, os quais se iniciam imediatamente após a interrupção do suprimento sanguíneo para os tecidos (GENOVESE ${ }^{4}, 1992$, OLIVER; SLOAN; PEMBERTON ${ }^{5}$, 2004). 
A fixação com solução de formol, a 10\%, deve ser realizada com volume de líquido de quinze a vinte vezes maior que o volume do espécime. Como a solução é consumida pelos tecidos, o volume desta deve ser suficiente para garantir a fixação do centro da peça (ABULÁFIA ${ }^{6}, 1973$, FLEURY ${ }^{7}, 1978$, MICHALANY ${ }^{8}$, 1979, NEVES; MARTINS; GREIN ${ }^{9}, 1981$, GENOVESE$^{4}, 1992$, TOMMASI $^{10}$, 2002, OLIVER; SLOAN; PEMBERTON ${ }^{5}$,2004). A fixação apropriada mantém as características do tecido e minimiza o aparecimento de artefatos que podem dificultar o exame histopatológico e conduzir ao erro no diagnóstico final (OLIVER; SLOAN; PEMBERTON ${ }^{5}$,2004).

Em 2003, AZEVEDO ${ }^{11}$ analisou as alterações microscópicas ocorridas com a idade, em glândulas sublinguais humanas, propondo-se a estudar o processo de envelhecimento. Um total de 186 glândulas sublinguais humanas foi coletado em 93 necropsias. Artefatos casuais encontrados ao longo de toda amostra, em glândulas de indivíduos de todas as idades, foram chamados de "autólise acinar". Nem informações literárias nem experiência prática de patologistas experientes explicaram o fenômeno. Tratava-se de um borramento nos limites celulares, onde, raramente, o contorno do ácino se perdia. Os núcleos das células acinares estavam soltos e próximos ao contorno do ácino. Os ácinos serosos pareciam menos afetados pelo processo quando comparados com os mucosos. Como o período post mortem para a necropsia dos cadáveres não era preciso em horas, não foi possível relacioná-lo ao aparecimento do artefato.

Em recente estudo morfométrico, usando a amostra de AZEVEDO ${ }^{11}$, MOREIRA $^{12}, 2005$, quantificou a densidade de volume de ácinos computando ácinos com autólise como se fossem ácinos normais, já que os limites dos ácinos estavam quase sempre mantidos a despeito do artefato entre as células que 0 formavam. Houve, entretanto, menção ao artefato, sem esclarecê-lo.

O processo descrito por AZEVEDO ${ }^{11}$, e MOREIRA ${ }^{12}$ como "autólise acinar" prejudicou, em parte, a interpretação individual das células e nenhuma explicação para o fenômeno foi encontrado na literatura sobre glândulas salivares. O assunto ficou, pois, aberto à investigação. 
2- REVISÃO DE LITERATURA 


\section{2 - ReVisão de Literatura}

\subsection{Anatomia e histologia das glândulas sublinguais de ratos}

As glândulas sublinguais do rato se diferenciam na vida pré-natal de tal maneira que, ao nascimento, já exibem todas as estruturas parenquimatosas características das glândulas dos animais adultos, mas ainda são imaturas (LEESON; BOTH $\left.{ }^{13}, 1961\right)$, crescendo significativamente na vida pós-natal $\left(\right.$ TAGA $^{14}, 1976$, HASSUNUMA; TAGA ${ }^{15}$, 1996, TAGA; SESSO ${ }^{16}, 1998$, TAGA; SESSO $^{17}$, 2002, MADI; CESTARI; TAGA $\left.{ }^{18}, 2003\right)$.

Entre as glândulas salivares maiores do rato albino de laboratório, as que exibem menor tamanho, são as glândulas sublinguais (LEESON ${ }^{19}, 1967$, PINKSTAFF $^{20}$, 1980). Essas glândulas são classificadas como túbulo-acinosas do tipo misto, predominantemente mucosa, ou seja, a maioria das suas unidades secretoras terminais é mista estando formadas por células mucosas típicas, envoltas por relativamente poucas células serosas periféricas (LEESON; BOTH ${ }^{13}$, 1961, TAGA ${ }^{14}, 1976$, TAGA; SESSO $^{16}, 1998$, TAGA; SESSO $^{17}, 2002$, LEESON $^{19}$, 1967, PINKSTAFF ${ }^{20}$, 1980, CULP; GRAHAM; LATCHNEY ${ }^{21}, 1991$, HERNANDES et al. ${ }^{22}, 1995$, LIMA $^{23}$ et al., 2004)

As células mucosas nos ácinos ou túbulos exibem forma piramidal, núcleos basais achatados e grânulos claros de muco preenchendo todo o citoplasma, enquanto as células serosas apresentam forma de semilua ou crescente, núcleos esféricos, basofilia basal e grânulos de secreção protéicos apicais (TAGA; SESSO ${ }^{16}$, 1998, TAGA; SESSO ${ }^{17}, 2002$, LEESON $^{19}, 1967$, PINKSTAFF $\left.{ }^{20}, 1980\right)$.

Essas estruturas secretoras terminais estão ligadas a um sistema altamente ramificado de ductos, que inicia com os ductos intercalares, passando 
por ductos cada vez maiores, os ductos estriados e os excretores, e termina num ducto único mais calibroso, o ducto excretor principal (LEESON; BOTH ${ }^{13}, 1961$, TAGA; SESSO ${ }^{16}, 1998$, LEESON $\left.^{19}, 1967\right)$.

O fato de ocorrer um claro predomínio de células mucosas na estrutura da sublingual que dependem de um estímulo nervoso para a secreção e que respondem a estímulo por secretagogos, torna esse órgão um modelo para o estudo da biologia da secreção mucosa (CULP; GRAHAM; LATCHNEY ${ }^{21}, 1991$, HERNANDES et al. ${ }^{22}$, 1995).

\subsection{Estudos relacionados à fixação e artefatos}

ABBEY; SWEENEY ${ }^{24}$, 1972, analisaram os artefatos de fixação em biópsias bucais. Os procedimentos, entre a excisão cirúrgica e a microscopia, são críticos para o sucesso da interpretação histológica. A fixação do material biopsiado é um fator incontrolável que causa grande influência nas condições finais do tecido a ser examinado. Os autores usaram a língua de 2 ratos para avaliar o tipo de fixação. As línguas foram divididas ao meio e fixadas em: água destilada, formol a 10\% 30 minutos após a excisão cirúrgica, solução salina a 0,9\% e, formol a 10\% imediatamente após a remoção. Observaram que procedimentos inadequados de fixação alteram severamente a arquitetura das células epiteliais. Para que possa ser feito o exame satisfatório, as peças devem ser fixadas imediatamente após o procedimento cirúrgico, em solução de formol neutro tamponado a $10 \%$.

WEIR; WEATHERS ${ }^{25}, 1976$, observaram acantólise em uma peça com hipótese de diagnóstico de papiloma. Para comprovar o artefato, os autores dividiram uma peça e a fixaram em dois frascos: um com formol a $10 \%$ e outro com o resíduo do formol evaporado. Após o processamento, no tecido fixado em resíduo de formol evaporado, havia acantólise no epitélio superficial. Assim, os 
autores concluíram que se a fixação não for feita corretamente, pode levar a um diagnóstico errôneo.

ZEGARELLI ${ }^{26}, 1978$, estudou os problemas comuns que podem ocorrer durante a biópsia, imediatamente após e depois da entrega da peça ao patologista. Ressaltou a importância de manusear o tecido com a mínima força, pois, ocasionalmente, tecidos removidos com força excessiva, podem apresentar artefatos que tornam a peça inutilizável para diagnóstico. Afirmou também que o formol e a água evaporam quando armazenados em recipientes inadequados, produzindo resíduos, o que leva a fixação inadequada levando ao erro de diagnóstico. Sugeriu que os laboratórios de patologia enviem o material a ser usado para fixação, eliminando, desta maneira, a maioria dos problemas encontrados durante biópsias bucais.

MARGARONE et al. $^{27}$, 1985, estudaram os artefatos cirúrgicos, de transporte e de fixação, durante e após biópsia bucal, procurando esclarecer quais destes interferem na análise histopatológica. Os seguintes artefatos foram avaliados: pelo fórceps, por calor (uso de eletrocauterização), por injeção (injeção de solução anestésica em excesso), de fixação, de congelamento, de transporte inadequado do espécime e de processamento inadequado. Segundo os autores, o artefato de fixação mostrou que o atraso ou fixação inadequada pode alterar qualitativamente a célula. O citoplasma apareceu desorganizado, o núcleo apresentou cromatina e nucléolo indistinguíveis, as estruturas vasculares e as glândulas perderam detalhe. Os ácinos das glândulas salivares menores foram mais susceptíveis a esse artefato de fixação, aparecendo opacos e acelulares, com desaparecimento do núcleo em algumas células.

FICARRA; MCCLINTOCK; HANSEN ${ }^{28}$, 1987, avaliaram os artefatos criados durante os procedimentos de biópsia bucal humana em 6 casos. Foram eles: artefatos de remoção cirúrgica imprópria, compressão, calor, fixação imprópria, dobra e artefato de corpo estranho. A fixação imprópria causou perda 
de detalhe e celularidade devido à autólise e putrefação. O citoplasma e a estrutura nuclear apareceram completamente indistintos. Como conclusão, para evitar o aparecimento de artefatos eles recomendaram: selecionar a melhor área para biópsia, submeter tecido suficiente para análise, fazer a remoção cuidadosamente, não contaminar o tecido, fixar imediatamente após a remoção, em formol a 10\%, com volume 20 vezes maior que do espécime e enviar dados clínicos suficientes para o patologista estabelecer o diagnóstico correto.

MOULE et al. ${ }^{29}$, 1995, compararam a biópsia incisional convencional com a biópsia por punch avaliando os artefatos criados. Foram realizadas 50 biópsias bucais, sendo 24 por punch e 26 por bisturi. O número de artefatos criados no grupo de biópsia por punch foi significantemente menor. A biópsia convencional pode causar artefatos como injúria com calor, frio e por fixação imprópria; enquanto a biópsia por punch só pode causar artefatos por fixação imprópria. Concluíram que a biópsia por punch cria uma menor quantidade de artefatos e que deveria ser mais utilizada, já que o acesso ao punch não é um problema.

Em 2004, OLIVER; SLOAN; PEMBERTON ${ }^{5}$, estudaram os métodos e aplicações das biópsias bucais. O material excisado precisa ser fixado com a finalidade de parar a autólise tecidual. A solução de escolha é o formol neutro tamponado a 10\%. O material deve ser fixado em uma quantidade de volume do fixador adequado, ou seja, 10 vezes o volume da peça. A fixação da peça em formol, forma pontes intermoleculares entre as proteínas e encadeamento cruzado entre proteínas e outros grupos. Se esse processo não ocorre logo após a remoção do tecido do corpo, esse tecido pode sofrer autólise, e dessa maneira, ficar histologicamente indecifrável. Deve-se também ter atenção com a técnica cirúrgica para minimizar a introdução de artefatos no tecido que irá para análise histológica. Os autores concluíram que uma apropriada fixação leva a um diagnóstico histológico confiável e inadequada fixação, pode impedir o diagnóstico da lesão e necessitar que a biópsia seja refeita. 


\subsection{Estudos relacionados à autólise}

HIBBS; BLACK ${ }^{30}, 1963$, realizaram um estudo do miocárdio de ratos em vários intervalos post mortem, procurando determinar a extensão e a natureza das alterações de autólise ocorridas durante as primeiras 10 horas. Espécimes foram retiradas imediatamente após a morte, 15 minutos, 1, 3, 5 e 10 horas depois da morte. Foram fixadas em fosfatase tamponada de tretóxido de ósmio a 1\% e analisadas no microscópio eletrônico. Foram encontradas várias mudanças com o decorrer do tempo, a primeira mudança notável, foi uma rápida diminuição do glicogênio. O núcleo encontrava-se com a cromatima mais granulosa e com a membrana nuclear intacta. Os autores concluíram que espécimes obtidos de autópsia devem ser usados para estudar as alterações ocorridas no tecido com a autólise, para poder diferenciá-las das alterações produzidas por doenças.

ARMIGE et al. $^{31}, 1976$, estudaram as mudanças morfológicas e bioquímicas de autólise no músculo cardíaco de 8 cachorros em diferentes períodos post mortem. Determinaram a relação da mudança de $\mathrm{pH}$, conteúdo de ácido láctico e aparência morfológica durante a autólise. O resultado foi que houve uma diminuição do pH e um aumento do ácido lático já com 10 minutos post mortem. Em microscopia óptica e eletrônica foram observadas pequenas alterações de autólise no núcleo, incluindo clumping da cromatina e picnose. Concluíram que a diminuição do pH e o aumento do ácido lático têm relação com as alterações morfológicas ocorridas durante a autólise.

PENTTILÃ; AHONEN ${ }^{32}$, 1976, avaliaram os efeitos da autólise no miocárdio do rato, por 20 dias, através da microscopia eletrônica e histoquímica de enzimas. As enzimas foram perdendo a atividade durante a autólise prolongada e mudanças ultra-estruturais foram vistas em um pequeno período de tempo de autólise. Os autores concluíram que as estruturas do miocárdio do rato são resistentes aos efeitos da autólise em temperatura ambiente e que os presentes achados ultra-estruturais mostram uma rápida perda do glicogênio associado com 
um rápido desaparecimento histoquímico da atividade da fosforilase do miocárdio durante a autólise. Essas observações estão em acordo com estudos anteriores.

NEVALAINEN; ANTTINEN ${ }^{33}$, 1977, realizaram um estudo ultraestrutural e funcional das alterações nas células acinares pancreáticas durante a autólise, com ratos Wistar. O pâncreas era removido e cortado em 4 pedaços, em uma temperatura entre 18 e $20^{\circ} \mathrm{C}$, nos períodos de 0 hora, 30 minutos, 1, 3, 6, 12 e 24 horas post mortem. Fizeram avaliação microscópica, da atividade da tripsina e da resposta secretória da amilase. A microscopia eletrônica revelou desintegração das células acinares, edema de vários compartimentos celulares e gradual desintegração das membranas celulares. Não foi encontrada atividade da tripsina nos tecidos e a secreção da amilase diminuiu conforme o período post mortem aumentou. Concluíram que durante a autólise das células acinares pancreáticas ocorre uma perda gradual da organização estrutural até chegar a desintegração celular.

NADOL JR; BURGESS ${ }^{34}, 1985$, avaliaram a autólise post mortem em 46 ossos temporal de 24 indivíduos, removidos durante a autópsia e preparados para microscopia eletrônica. Características de autólise, incluindo vacuolização dos neurônios, lise dos limites das membranas e dos filamentos de suporte da célula, edema do retículo endoplasmático e dissolução da crista mitocondrial foram vistas. Consideraram que o tempo post mortem e a causa da morte interferem na adequada preservação histológica. Portanto é necessário habilidade para diferenciar alterações patológicas com autólise post mortem e outros artefatos como os de trauma mecânico e técnica de fixação.

EL-SHENNAWY; GEE; APARÍCIO ${ }^{35}, 1985$, descreveram as alterações de autólise post mortem nos túbulos proximal e distal no rim esquerdo de ratos Wistar. Pedaços do rim foram retirados às 0, 4, 12, 24 e 48 horas post mortem. Foram encontradas alterações completamente diferentes daquelas que aparecem usualmente depois da morte e parecidas com aquelas vistas na apoptose. Com 
suas observações, sugeriram que as alterações citoplasmáticas no túbulo distal podem ser mais rápidas que as do túbulo proximal.

SUKURA; SOVERI; LINDBERG ${ }^{36}$, 1990, quantificaram morfometricamente as primeiras alterações de autólise no músculo cardíaco de ratos em microscopia eletrônica. Foram utilizados 25 ratos. O coração dos animais foi fixado imediatamente após a morte, 1, 5, 10 e 25 minutos após a morte. O grupo controle foi fixado por perfusão e os demais grupos fixados por imersão em glutaraldeído a 2,5\%. O resultado deste estudo indicou mudanças estatisticamente significantes na densidade de volume dos componentes citoplasmáticos do músculo cardíaco, ocorrendo rapidamente após a morte.

SHIMIZU et al. ${ }^{1}, 1990$, avaliaram o pâncreas de 92 necropsias para determinar a influência das condições clinicopatológicas sobre a extensão da autólise post mortem. A autólise pancreática foi classificada em categorias: grau 0 (sem autólise), grau 1 (até 1/3 do corte com autólise), grau 2 (entre 1/3 e 2/3 do corte com autólise) e grau 3 (mais de 2/3 do corte com autólise). A morfologia da autólise foi determinada pela necrose das células com ausência de sinais de inflamação e inexistência de neutrófilos. A autólise foi descrita com caracteres de necrose, ou seja, cariólise, picnose e cariorrexe. Idade, sexo, raça, causa da morte, intervalo post mortem, temperatura do corpo no momento da morte e modo da morte foram considerados na avaliação. O autor concluiu que o intervalo post mortem é o fator que mais influencia na autólise, provocando o aumento desta com o passar do tempo.

PALLOT; SEKER; ABRAMOVICI ${ }^{37}$, 1992, examinaram os efeitos post mortem das mudanças na estrutura de células do tipo I do corpo carotídeo de ratos. Utilizaram 24 ratos Wistar, removeram o corpo carotídeo em diferentes intervalos post mortem (0, 2, 4, 8, 16 e 24 horas). As peças foram mantidas em temperatura ambiente e fixadas em formalina neutra tamponada a $4 \%$, corados a seguir com HE e PAS. Nos resultados, das peças examinadas imediatamente 
após a morte, a célula do tipo I exibia morfologia similar ao normal. Já, com a demora para ocorrer a fixação, a célula sofreu autólise, concluindo que a demora para fixar pode causar danos as células.

CINGOLANI et al. ${ }^{38}$, 1994, procuraram demonstrar as alterações autolíticas em glândulas sudoríparas e identificar parâmetros que pudessem ajudar a determinar o tempo de morte, nas primeiras horas post mortem. Amostras da pele da superfície ventral do braço de 29 indivíduos de diferentes idades foram removidas em intervalos de tempo de 3, 6, 9 e 12 horas post mortem. Três tipos de testes foram realizados: citoquímico (H/E e PAS), imunohistoquímico (S-100, CEA, Citoqueratina e MAS) e ultra-estrutural (microscopia eletrônica). A microscopia óptica (estudo citoquímico e imunohistoquímico) revelou progressiva retração do citoplasma, prova de degeneração celular e presença de vacúolo citoplasmático vazio em células glandulares. A microscopia eletrônica mostrou alterações específicas de cada etapa estudada, como redução do glicogênio intracelular nas células claras e dos grânulos de secreção nas células escuras típicas das primeiras 3 horas post mortem. Também foi observada, dilatação das mitocôndrias e rarefação de sua crista em células claras e escuras (6 horas) e, rarefação das microvilosidades das células claras e escuras (12 horas). Houve ainda redução da integridade da membrana celular e alterações nas células dos ductos.

MUÑOZ et al. ${ }^{39}$, 1999, utilizaram métodos morfométricos e microscopia eletrônica na tentativa de estabelecer a relação entre o tempo post mortem e as alterações autolíticas ultra-estruturais do miocárdio. Foram obtidos fragmentos do miocárdio de quatro cachorros adultos durante a anestesia (controle zero), e com 15, 30, 45, 60, 90, 120 e 240 minutos, depois da morte por parada cardíaca, mantendo o coração in situ. Alterações autolíticas significantes foram vistas nos núcleos, glicogênio, miofibrilas, retículo sarcoplasmático, espaço perinuclear e, especialmente, nas mitocôndrias. Houve diminuição do número e aumento no volume mitocondrial. Neste estudo, a natureza progressiva das alterações foi 
demonstrada quantitativamente, embasando a correlação com o tempo post mortem.

AZEVEDO et al. $^{11,40,41}$, 2004, analisou as alterações microscópicas ocorridas com a idade em glândulas sublinguais humanas, propondo-se a estudar o processo de envelhecimento. Um total de 186 glândulas sublinguais humanas foi coletada em 93 necropsias realizadas no Serviço de Verificação de Óbitos da Capital (SVOC, ligado à Faculdade de Medicina da Universidade de São Paulo USP). Artefatos casuais encontrados ao longo de toda amostra em glândulas de indivíduos de todas as idades foram chamados de "autólise acinar", pela inexistência de informações literárias sobre o tema. Tratava-se de um borramento nos limites das células, quase sempre sem perda do contorno do ácino. Os núcleos das células acinares estavam soltos e próximos ao contorno do ácino. Os ácinos serosos pareciam menos afetados pelo processo quando comparados com os mucosos. Como o período post mortem para a necropsia dos cadáveres não era preciso em horas, não foi possível relacioná-lo ao aparecimento do artefato. A fixação dos espécimes foi com formalina e seguiu padrão de rotina do Serviço.

TOMITA et al. $^{42}, 2004$, examinaram alterações ultra-estruturais de autólise post mortem em rim, pâncreas, fígado, coração e músculo cardíaco de 18 ratos Wistar, machos, com 6 semanas de vida. Os órgãos foram removidos nos períodos de 1, 3, 5, 10, 15 e 24 horas post mortem e fixados em glutaraldeído a $2,5 \%$ e depois, fixados em tetróxido de ósmio a 1\%. Foi encontrado edema celular, aparecimento de depósitos densos amorfos nas mitocôndrias, perda dos grânulos de glicogênio, dilatação do retículo endoplasmático, agrupamento e marginação da cromatina nuclear em diferentes períodos e órgãos examinados. Nas células acinares do pâncreas foram vista duas formas de mudança nuclear: uma semelhante à mudança necrótica e outra com mudança apoptótica. Puderam concluir que o processo de autólise post mortem depende de vários fatores como temperatura, umidade do ar e tipo de ambiente; por isso, deve-se levar em consideração os efeitos da extirpação. 
MOREIRA $^{12}$, 2005, realizou um estudo morfométrico, em glândulas sublinguais humanas, com o objetivo de avaliar as modificações morfológicas quantitativas em glândulas sublinguais humanas relacionando-as com a idade cronológica e o gênero. Noventa glândulas sublinguais direitas de cadáveres humanos foram utilizadas para análise dos vários componentes glandulares e do volume glandular. Artefatos casuais encontrados ao longo de toda amostra em glândulas de indivíduos de todas as idades foram chamados de "autólise acinar", e para quantificar a densidade de volume de ácinos computou ácinos com autólise como se fossem ácinos normais, já que os limites dos ácinos estavam quase sempre mantidos, a despeito do artefato. O artefato encontrado não interferiu nos resultados analisados.

Nota-se que alguns artigos específicos relacionados com autólise estudaram o fenômeno em outros órgãos ou tecidos de animais ou humanos. A inexistência de estudos sobre o fenômeno de autólise em glândulas salivares faz com que haja apenas especulações a respeito dos achados observados nas glândulas sublinguais humanas (AZEVEDO ${ }^{40,41}$ ). 
3- PROPOSICÃO 


\section{3 - Proposição}

Pretende-se quantificar, morfometricamente, no microscópico óptico, a densidade de volume e o volume absoluto dos ácinos íntegros e autolisados, em glândulas sublinguais de ratos fixadas com solução de formol a 10\% em tampão fosfato, considerando, diferentes intervalos post mortem e variação no volume do fixador. 
4-MATERIAL E MÉTODOS 


\section{4- Material e Métodos}

No atual trabalho foram utilizados 60 ratos (Rattus novergicus, variedade albina, Wistar) adultos, com 120 dias de idade, provenientes do Biotério Central da Faculdade de Odontologia de Bauru, da Universidade de São Paulo. Esses animais foram mantidos desde o nascimento em lotes de 8 filhotes por mãe, sendo desmamados no $21^{\circ}$ dia.

Dos sessenta animais empregados neste estudo (Figura 1), cinqüenta deles foram divididos em 2 grupos, denominados I e II. O grupo I (25 animais) foi utilizado para as avaliações morfométricas e o grupo II (25 animais) foi destinado à determinação do fator de retração e da densidade da glândula. Os grupos I e II foram subdivididos nos subgrupos: A e A1 (controle), que receberam fixação imediata; subgrupos $\mathrm{B}$ e B1, fixação 3 horas post mortem; subgrupos C e C1, fixação 6 horas post mortem; subgrupos D e D1, fixação 12 horas post mortem; e subgrupos E e E1, fixação 24 horas post mortem. Cada grupo era constituído de 5 animais por período post mortem. As glândulas direita e esquerda foram utilizadas nesta etapa, onde a fixação foi realizada com $20 \mathrm{~mL}$ de solução de formol a 10\% em tampão fosfato. Os 10 animais remanescentes dos 60 (Figura 1) foram destinados ao estudo da variação de volume do fixador. As glândulas sublinguais de 5 animais foram fixadas com 2 $\mathrm{mL}$ de solução de formol tamponado a $10 \%$, ou seja, um volume apenas suficiente para cobrir a peça num frasco de $2 \mathrm{~cm}$ de diâmetro. As glândulas sublinguais dos 5 animais restantes foram fixadas com $20 \mathrm{~mL}$ do mesmo fixador em um frasco de $2 \mathrm{~cm}$ de diâmetro. 


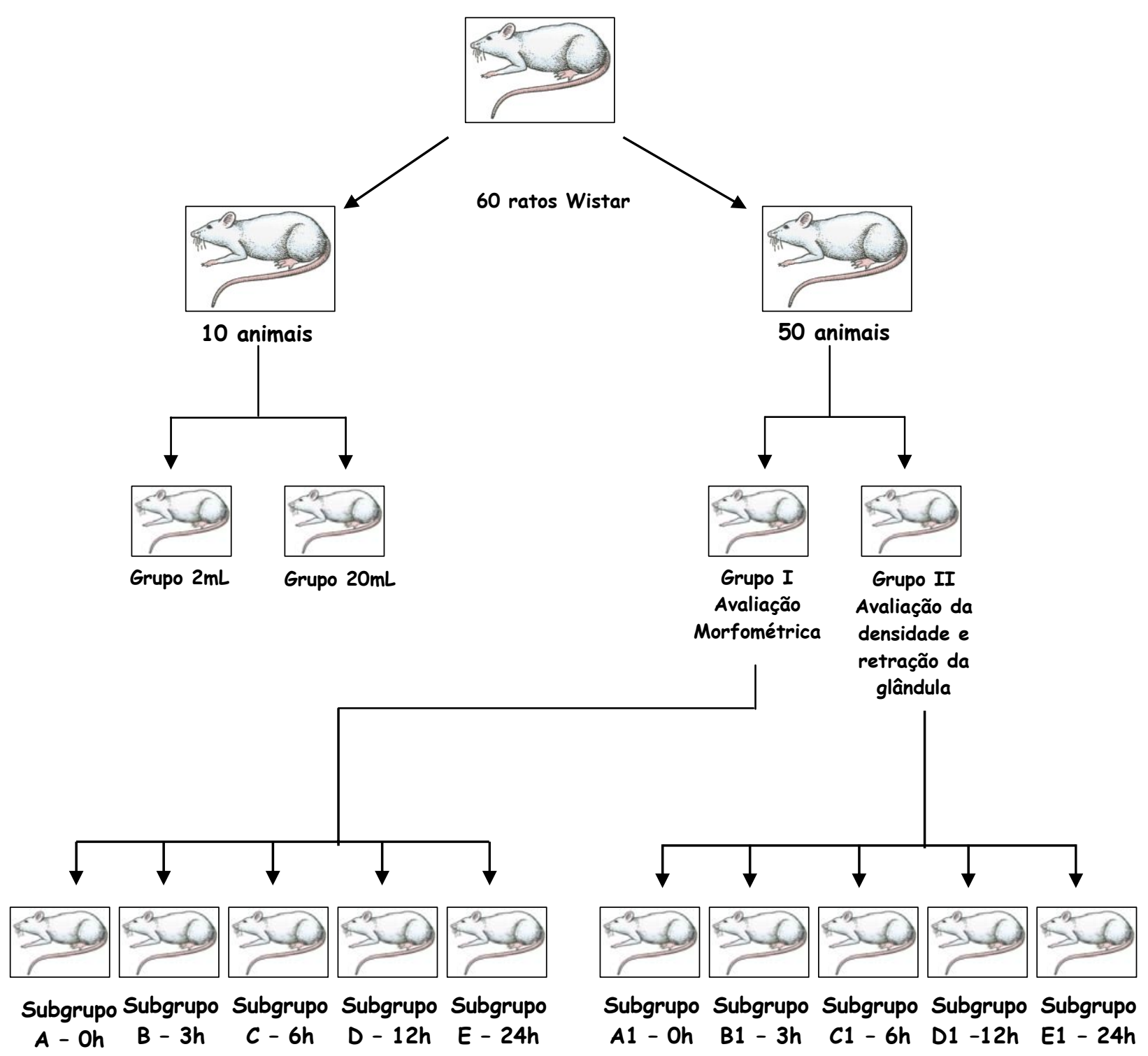

FIGURA 1. Esquema de distribuição dos animais para os diferentes ensaios da pesquisa

\subsection{Sacrifício dos animais}

Antes da indução da anestesia foi administrado atropina (Soluto de atropina 1,25\%, Laboratório Prado AS, Curitiba-Pr) na dosagem de 4,0mg/Kg de massa corporal e após o período de 5 minutos, o sacrifício dos animais foi realizado através de dose excessiva de anestésico (Cloridrato de Ketamina e Cloridrato de Xilazina - nome comercial Dopalen e Anasedan - Agribrands do Brasil Ltda.) (Figura 2). Após o sacrifício, os animais permaneceram em temperatura ambiente e suas glândulas foram cuidadosamente dissecadas e coletadas em períodos entre 0 e 24 horas (Figura 3). Elas foram pesadas em balança de precisão (Mettler Toledo AT261 Delta Rang) (Figura 4) e 
imediatamente colocadas na solução fixadora permanecendo por 7 dias em fixação.
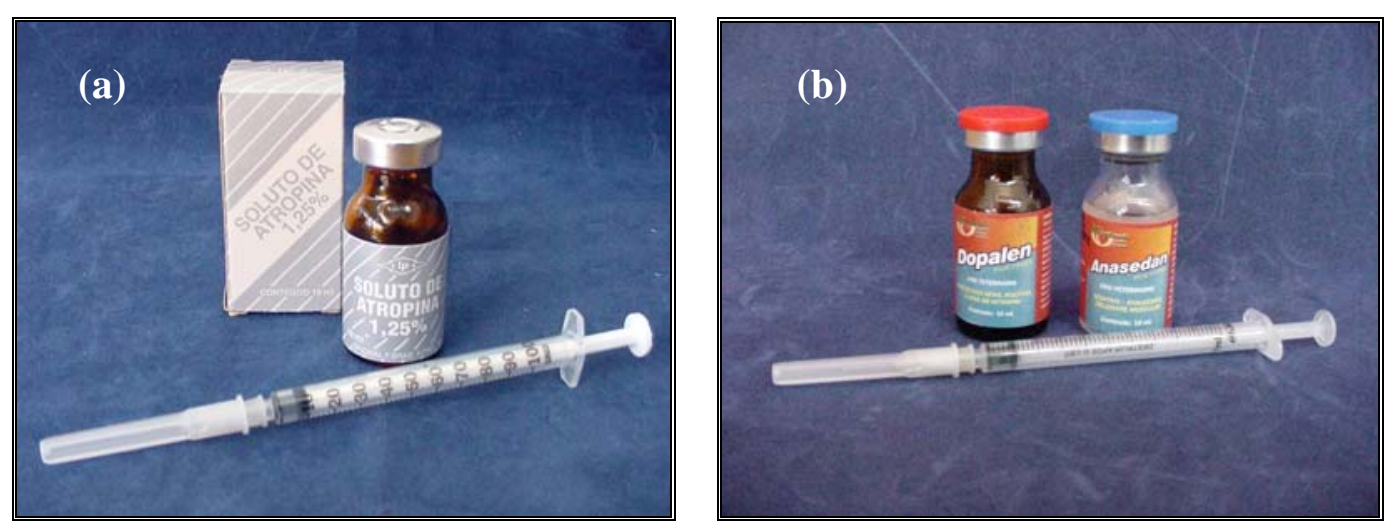

FIGURA 2. a) Solução de atropina e b) Medicamentos usados para obtenção do sacrifício dos animais
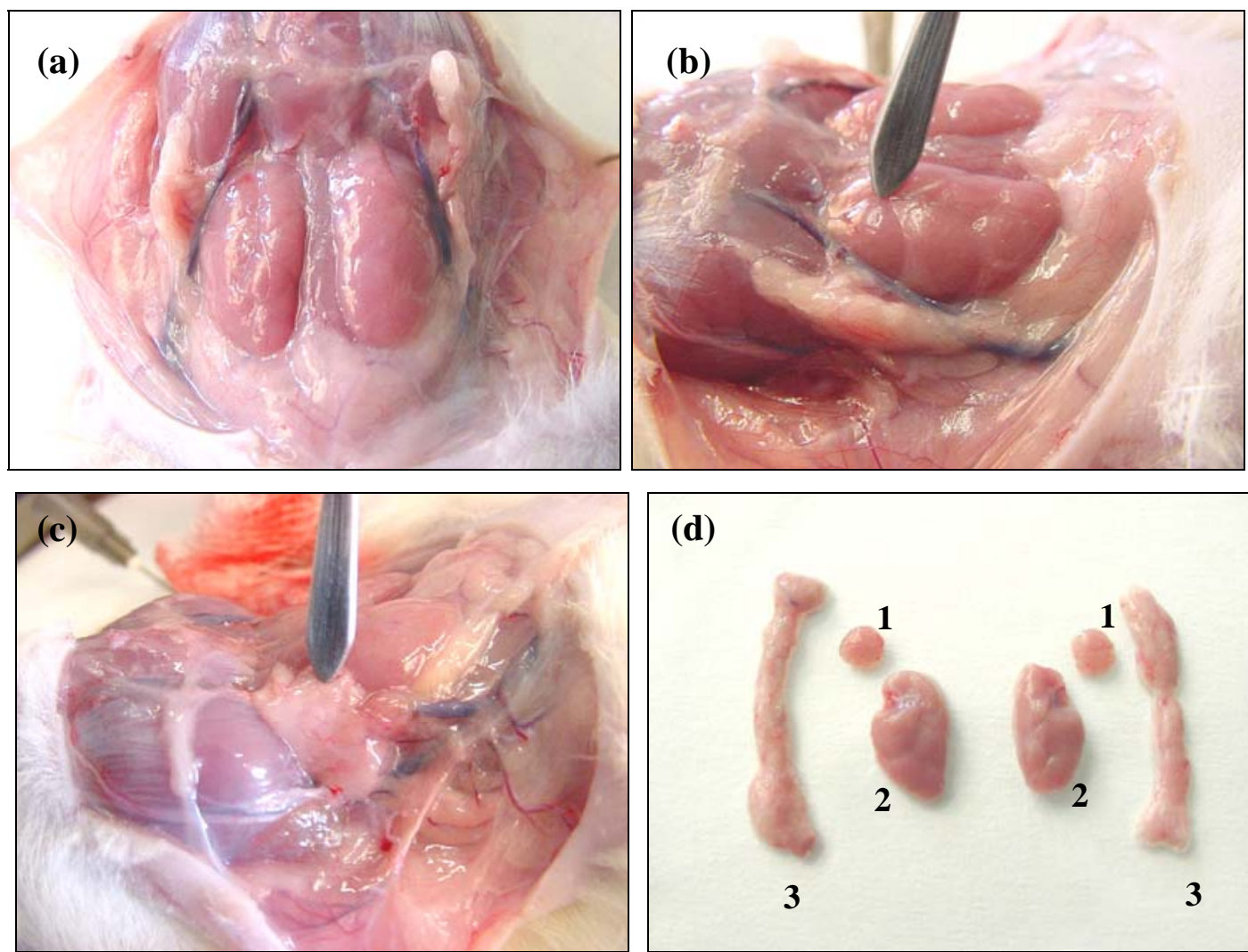

(d)

FIGURA 3. Seqüência da dissecação das glândulas sublinguais. a) rebatimento da pele na região ventral do pescoço; b) localização das glândulas sublingual (apontada) e submandibular; c) localização da glândula parótida; d) glândulas sublinguais (1), submandibulares (2) e parótidas (3) 

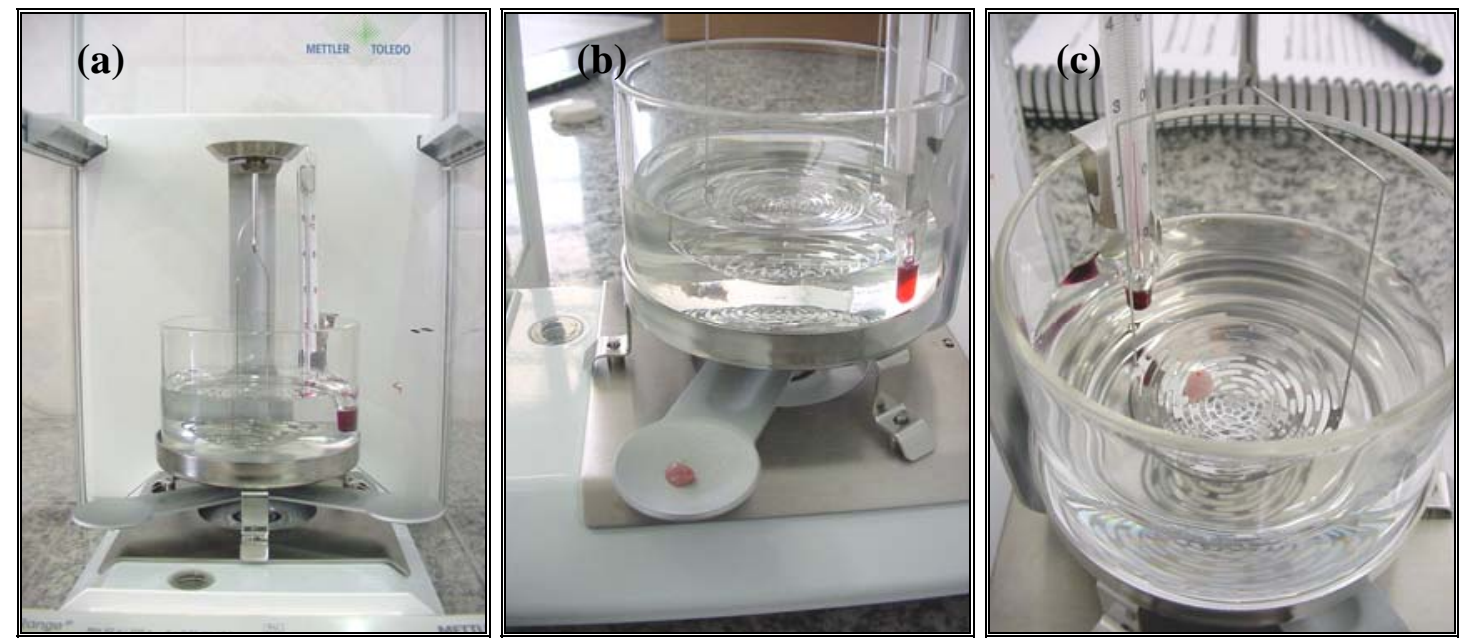

FIGURA 4. Determinação da densidade da glândula: a) balança Mettler Toledo AT261 Delta Rang, contendo conjunto de acessórios Metler AT/AG e PG/PG-S/PR para determinação da densidade de sólidos; b) determinação da massa fresca glandular (m); e c) determinação do volume de água deslocado (v)

\subsection{Procedimentos Histológicos}

O processamento do material foi realizado no laboratório de Histologia da Faculdade de Odontologia de Bauru - USP.

As glândulas foram lavadas em água corrente durante 24 horas e, em seguida, mantidas em álcool 70\% por mais 24 horas. No dia subseqüente, o material foi submetido a procedimentos estandardizados de desidratação em álcool etílico, clarificação em xilol e embebição em Histosec - Merck (parafina + resina plástica). Cortes alternados de $5 \mu \mathrm{m}$ de espessura de cada glândula foram obtidos em micrótomo Jung-Leitz Multicut e corados pela técnica da hematoxilina - eosina.

\subsection{Determinação do volume processado}

Para a determinação de parâmetros morfométricos de natureza absoluta, como o volume total de cada ácino, existe a necessidade de conhecermos o volume do órgão após todas as fases do processamento histológico.

O volume processado ( $\mathrm{Vp}$ ) pode ser estimado utilizando-se da massa fresca $(\mathrm{m})$ da glândula sublingual, desde que conheçamos a densidade (d) do órgão e o percentual de retração provocado pelo processamento histológico (FR), pela seguinte relação: 


$$
\mathrm{Vp}=\frac{\mathrm{m}}{\mathrm{d}} \cdot \mathrm{FR}
$$

\subsubsection{Avaliação da densidade da glândula}

A densidade (d) da glândula sublingual foi avaliada na glândula direita de cada animal do grupo II. Cada glândula foi pesada em uma balança Mettler Toledo AT261 Delta Rang, contendo conjunto de acessórios Metler AT/AG e PG/PG-S/PR para determinação da densidade de sólidos. O cálculo foi baseado no Princípio de Archimedes, onde a densidade de um corpo (d) = $(\mathrm{m} / \mathrm{v})$.dágua; onde: $\mathrm{m}=$ massa da glândula, $\mathrm{v}=$ volume de água deslocado, $\mathrm{e}$ $\mathrm{d}_{\text {água }}=$ densidade da água a temperatura de $18^{\circ} \mathrm{C}$.

\subsubsection{Determinação da retração provocada pelo processamento histológico}

A retração provocada pelo processamento histológico foi avaliada na glândula sublingual esquerda de cada animal do gupoll.

Inicialmente, a glândula coletada foi colocada sobre um papel de filtro, posicionado sobre uma placa de cera rosa $n^{0} 7$, e levada até o congelador por 5 minutos, para aumentar a firmeza do tecido.

Em seguida, foi recortada com uma lâmina, dando um perfil retangular e cada fragmento foi levado para uma lupa Bausch \& Lomb, com uma lente objetiva de $0,63 x$, onde foi acoplada uma ocular micrométrica Olympus de 10x, tipo Ramsden com filamento deslocável, e as dimensões do comprimento e largura foram obtidas e convertidas para micrômetro.

Em seguida, os fragmentos receberam os procedimentos histológicos padronizados, chegando até a inclusão no bloco de Histosec ${ }^{\circledR}$ (Merck). Nesta fase, o fragmento emblocado foi levado novamente até a lupa onde foram determinadas as dimensões da superfície retangular, como o papel de filtro deixa uma superfície lisa em um dos lados da glândula, quando o retângulo é colocado no fixador, é possível medir sempre o mesmo lado.

As medidas dos lados, obtidas para todos os fragmentos nas duas situações, foram somadas e o resultado dividido por 4 para achar um lado médio, ou seja, transformar um retângulo em um quadrado equivalente. Esse valor foi elevado à terceira potência e o volume do fragmento da glândula foi 
obtido a fresco (Sf) e após o processamento até bloco (Sp) já que é considerado ser desprezível a retração do material entre a fase de bloco até a sua coloração. O fator de retração $(\mathrm{Fr})$ foi estimado a partir da relação:

$$
\mathrm{Fr}=\mathrm{Sp}^{3} / \mathrm{Sf}^{3} \text {. }
$$

\subsection{Estudo Morfométrico*}

\subsubsection{Casualização dos campos histológicos}

Todos os métodos estereológicos são baseados em princípios geométricos - estatísticos, derivados da probabilidade em que imagens dos perfis da estrutura na secção histológica coincidam com um sistema-teste apropriado. Deste modo, o ponto central nestes métodos está na casualização das amostras, ou seja, a escolha das amostras do tecido a serem confrontadas com o sistema-teste, deve ser realizada por um método que elimine a ocorrência de vício na amostragem.

De cada glândula foram obtidas 20 lâminas contendo 3 cortes semiseriados cada uma. Através de sorteio foram escolhidas 5 lâminas para serem utilizadas e de cada lâmina selecionado um (1) corte histológico. Neste corte histológico, foram contados 10 campos, totalizando 50 campos por animal.

Para a escolha dos 50 campos histológicos por corte, utilizamos um esquema de casualização sistemática segundo as indicações de WEIBEL ${ }^{43}$, (1969) (Figura 5). Na amostragem sistemática, os campos histológicos são escolhidos a intervalos regulares em cada corte histológico, de tal maneira a ter uma amostra representativa de toda área do corte (TAGA, R.; SESSO, A.; PARDINI, L.C. $\left.{ }^{44}, 1998\right)$.

\footnotetext{
* O Estudo morfométrico foi orientado pelo Prof. Dr. Rumio Taga, do Departamento de Ciências Biológicas da FOB-USP, com experiência comprovada em vasta linha de investigação em animais. As medições foram realizadas pela candidata.
} 


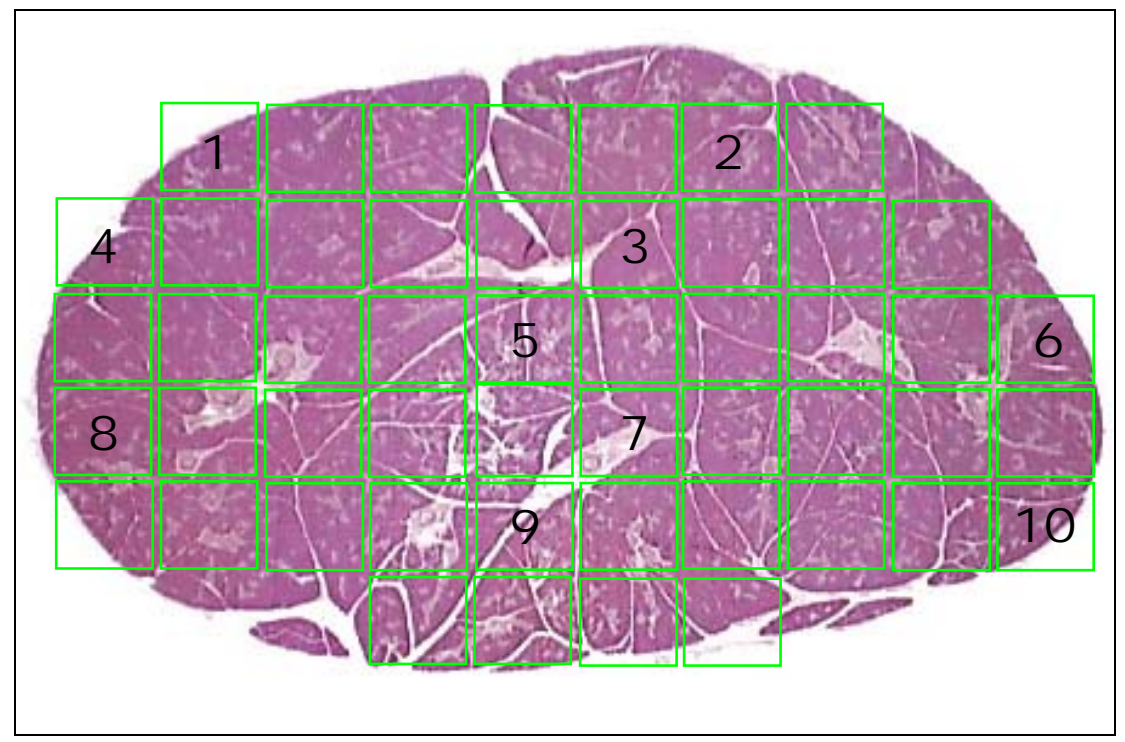

FIGURA 5. Esquema de casualização dos 10 campos microscópicos por corte histológico

\subsubsection{Sistema-teste utilizado nas avaliações morfométricas}

Para as avaliações morfométricas foi utilizado um microscópio Olympus com objetiva de 100x e ocular Kpl 8x Zeiss contendo um retículo de integração II Zeiss, constituído por 10 linhas paralelas e 100 pontos simetricamente distribuídos dentro de uma área quadrada.

\subsubsection{Determinação da densidade de volume (Vvi) dos ácinos íntegros e autolisados}

A densidade de volume (Vvi) ou fração de volume glandular ocupada por uma determinada estrutura (i) foi avaliada pela técnica de volumetria relativa de contagem de pontos (WEIBEL $\left.{ }^{43}, 1969\right)$.

Este método é baseado em princípios básicos onde a fração de volume ocupada por uma estrutura (i) é proporcional à fração de área ocupada por perfis do mesmo objeto, sendo: Vvi = AAi. A fração de área pode ser determinada colocando-se sobre a amostra um retículo de pontos arranjados regularmente e contando o número de pontos que caiam sobre a estrutura interessada, ou seja: $A A i=$ PPi.

Nos campos histológicos casualizados por espécime, foram anotados o número de pontos sobre os ácinos (Pi) e o número total de pontos sobre a glândula (Pt) (Figura 6). A densidade de volume de ácinos (íntegros e autolisados) foi calculada pela seguinte relação: $\mathrm{V} v i=\mathrm{Pi} / \mathrm{Pt}$ 


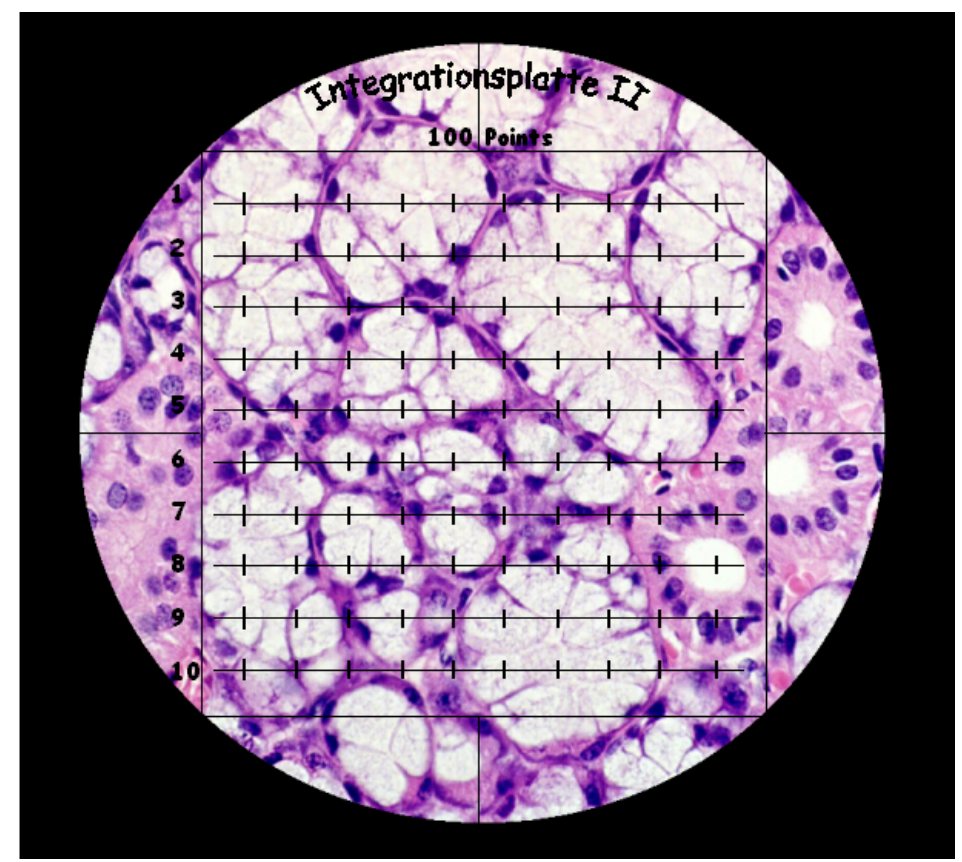

FIGURA 6. Determinação da densidade de volume de cada estrutura pela contagem de pontos. Esquema ilustrativo

A densidade de volume (Vvi) é expressa como porcentagem ou como uma fração de 1.

\subsubsection{Determinação do volume absoluto ( $\mathrm{Vt}$ ) dos ácinos íntegros e autolisados}

Conhecendo-se o volume glandular processado (Vp), o volume absoluto dos ácinos autolisados e íntegros $(\mathrm{Vt})$ foi calculado pela fórmula:

$$
\mathrm{Vt}=\mathrm{V} v \mathrm{x} \times \mathrm{Vp}
$$

\subsubsection{Determinação do coeficiente de variação da média ("erro")}

O coeficiente de variação da média ("erro"), associado à avaliação da densidade de volume ( $\mathrm{V} v i)$ foi determinado pela aplicação da relação:

$$
\mathrm{e}=\sqrt{\frac{1-\mathrm{Ppi}}{\text { Pt.Ppi }}}
$$

onde,

e = "erro" (coeficiente da variação da média da proporção);

Ppi = fração de volume ocupada pela estrutura na glândula;

$\mathrm{Pt}=$ número total de pontos sobre a glândula $\left(\mathrm{PARDINI}^{45}, 1985, \mathrm{SCHAEFER}^{46}\right.$, 1970) 


\subsubsection{Critérios adotados nas quantificações}

A análise morfométrica foi realizada de acordo com os seguintes critérios:

a) ácinos íntegros: a contagem englobava os ácinos mistos ou mucosos íntegros. Eles foram aferidos como uma só variável. (Figura 7)

b) ácinos autolisados: a contagem englobava os ácinos mistos, ou mucosos (Figuras 8, 9 e 10). Eles eram computados desde que tivessem um mínimo sinal de autólise, independente da gradação do fenômeno.

c) outros: incluiu a contagem de ductos, vasos sangüíneos, nervos, infiltrado inflamatório e estroma, este representado pelo tecido conjuntivo. Eventuais artefatos foram também, aqui computados (Figura 11).

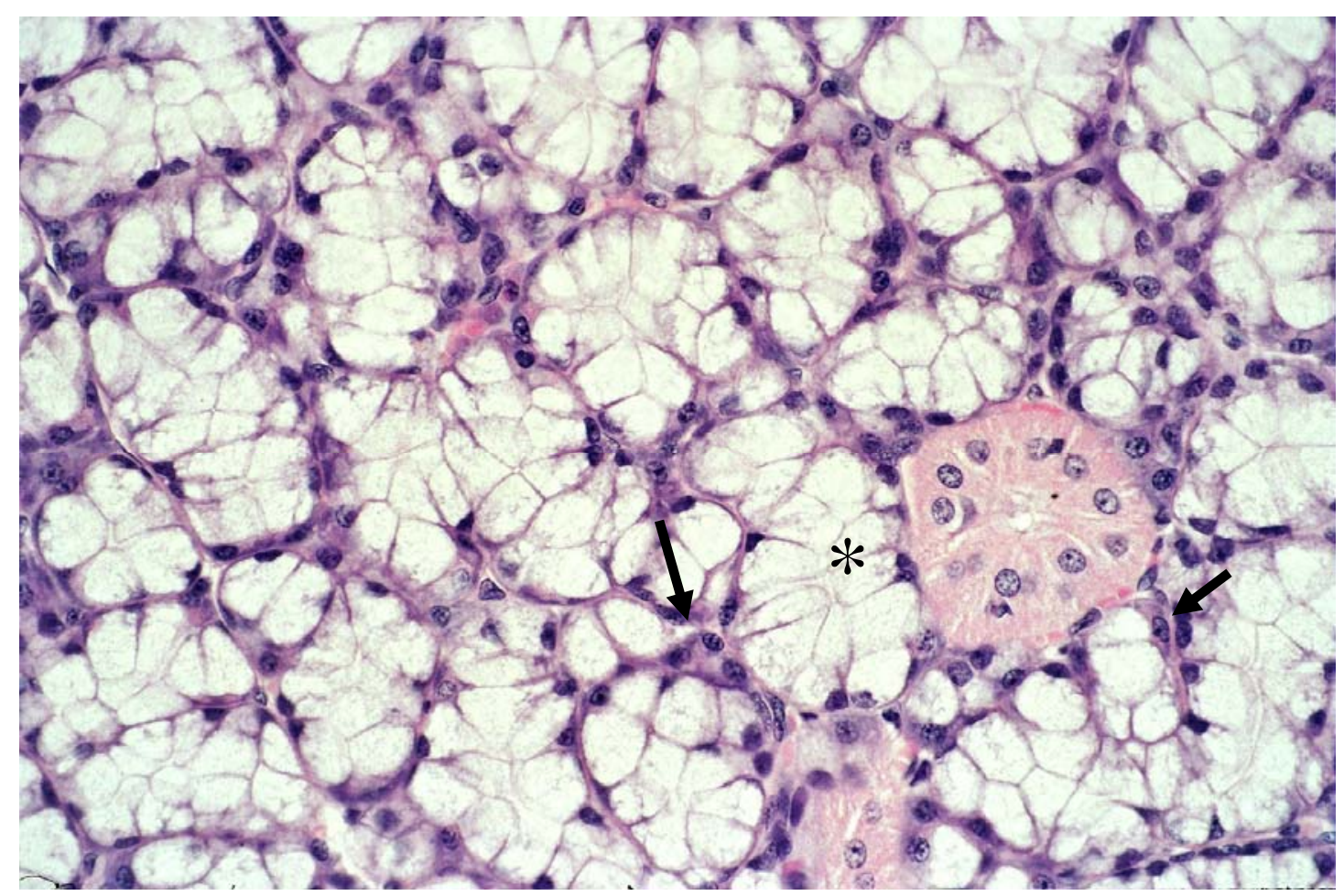

FIGURA 7. Ácinos mucosos (*) e mistos (setas) íntegros (HE aumento de 384x 0h/20ml) 


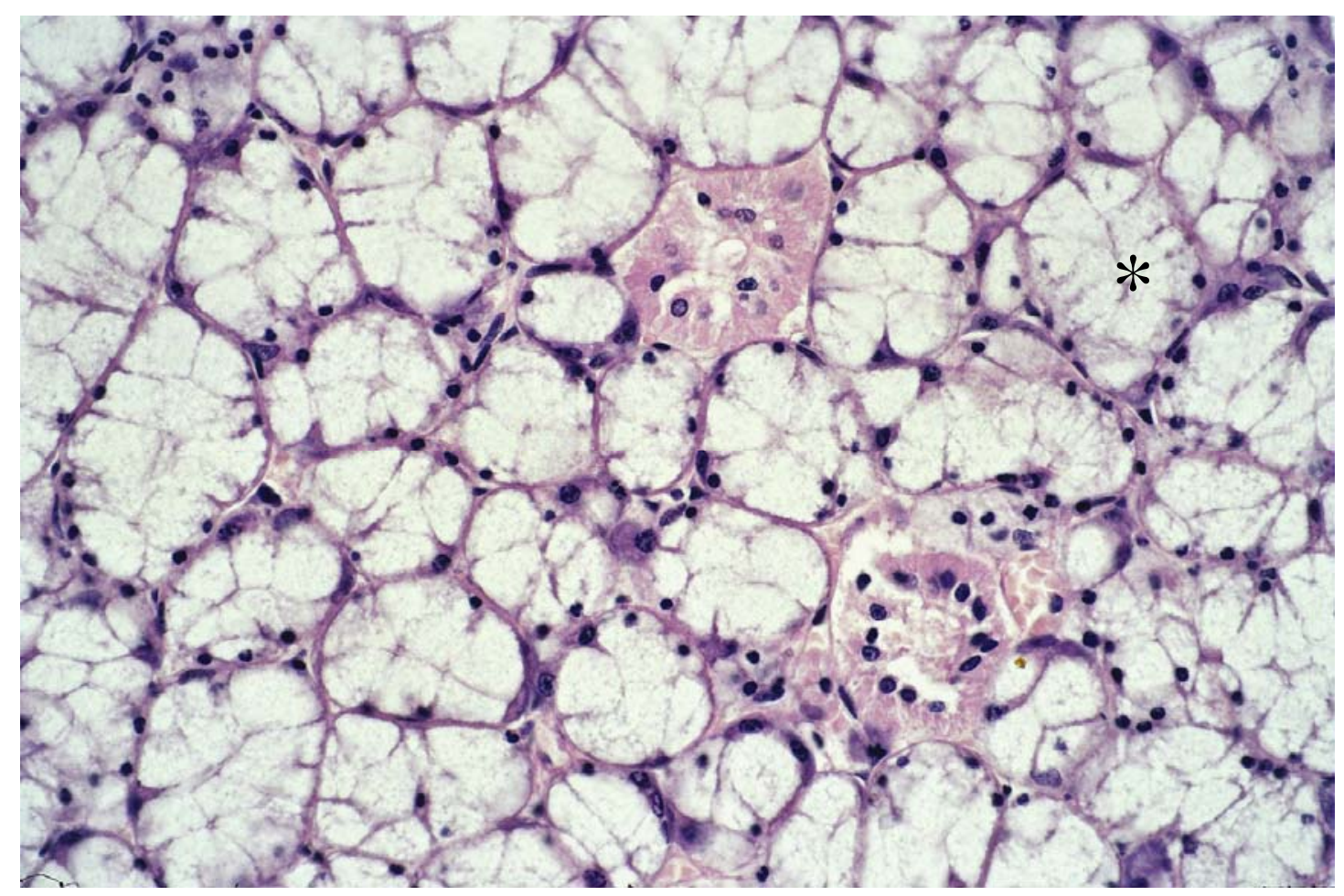

FIGURA 8. Ácinos mistos e mucosos (*) em estágio inicial de autólise (HE aumento de $384 \times 12 \mathrm{~h} / 20 \mathrm{ml}$ )

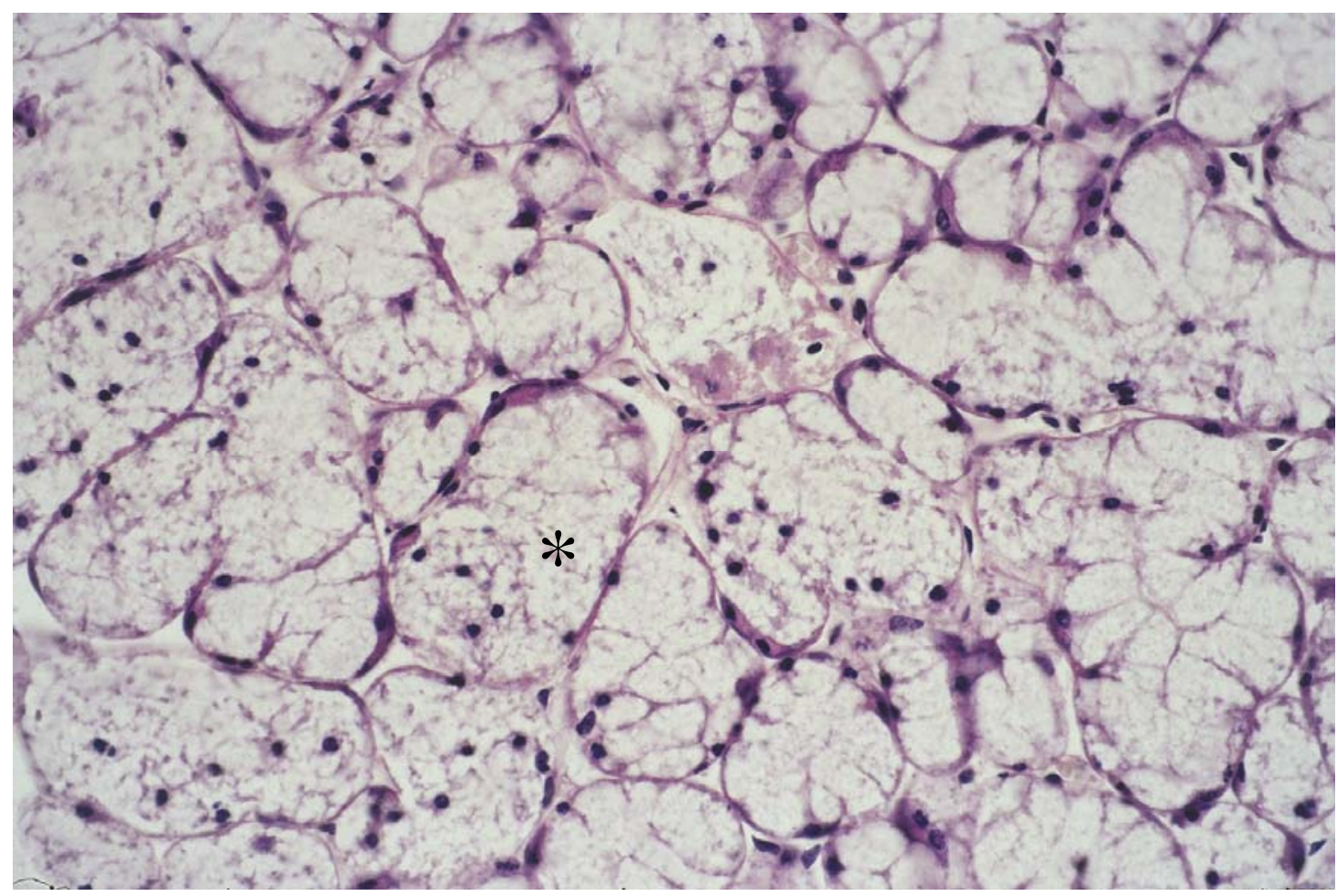

FIGURA 9. Ácinos mistos e mucosos em estágio intermediário de autólise (HE aumento de $384 \times 12 \mathrm{~h} / 20 \mathrm{ml}$ ) 


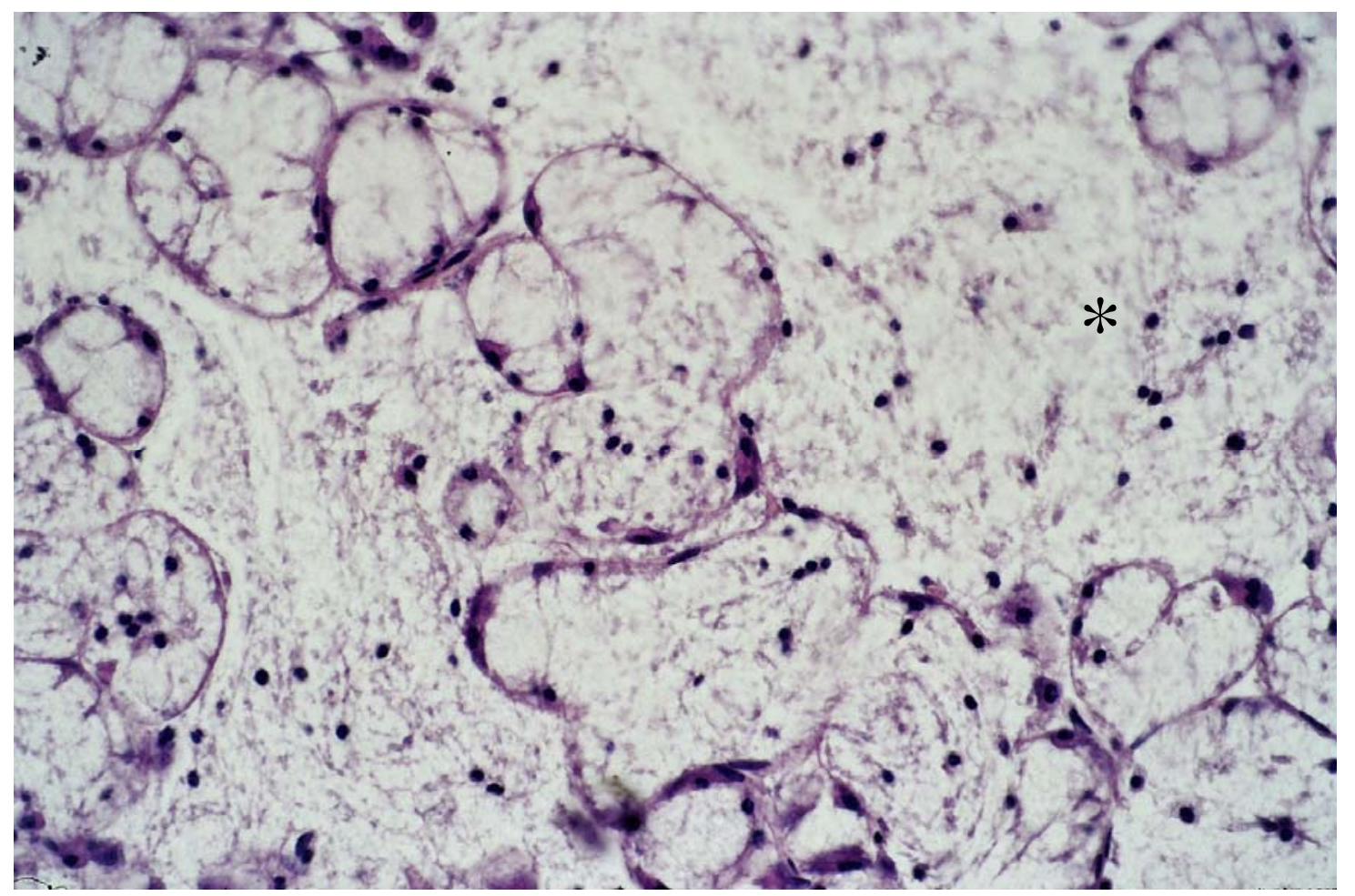

FIGURA 10. Ácinos em estágio final de autólise (HE aumento de 384x 12h/2ml)

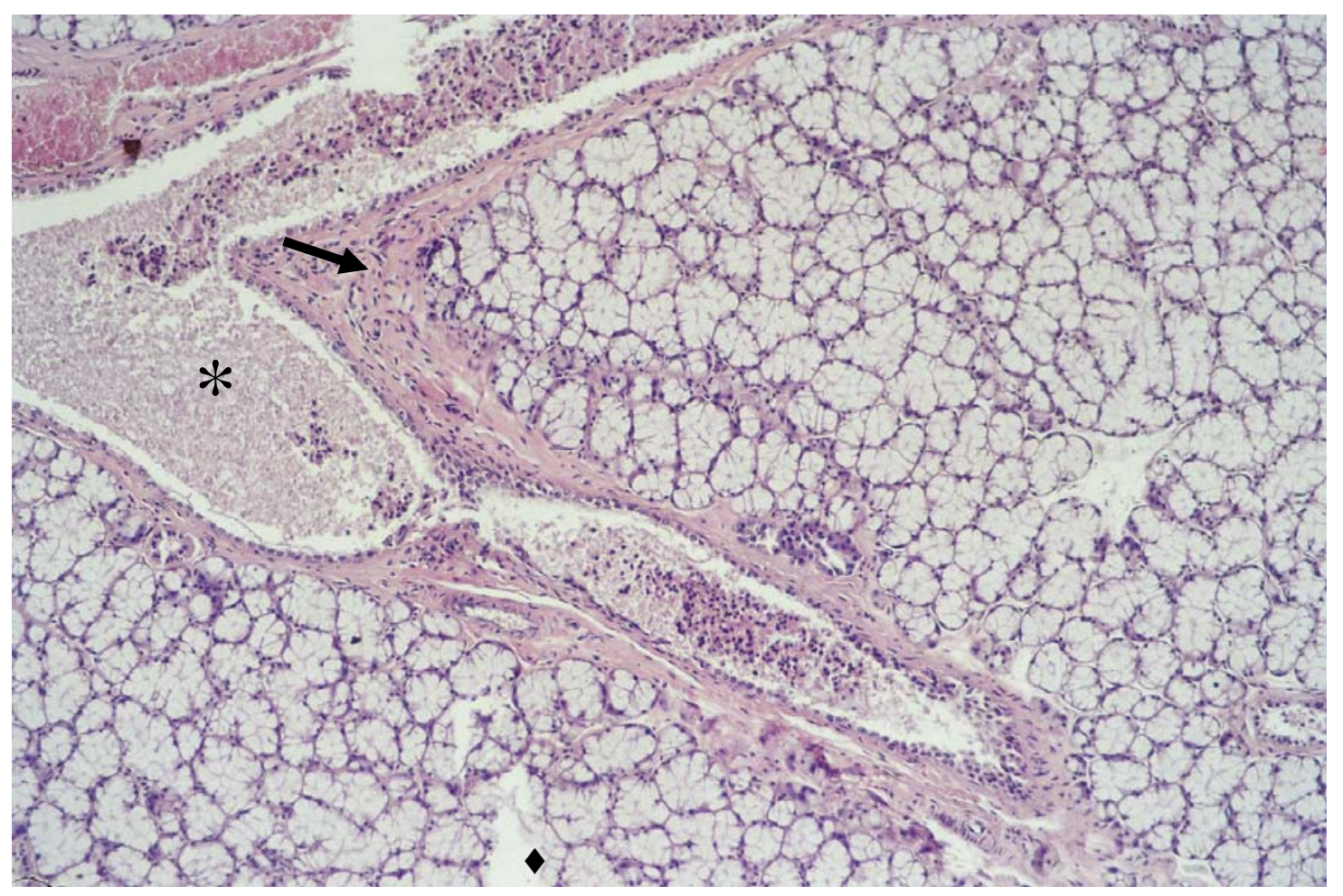

FIGURA 11. Estruturas quantificadas como outras, ductos (*), septo (seta) e artefato de técnica (•) (HE aumento de 96x 12h/2ml) 


\subsection{Tratamento estatístico dos dados}

Os valores obtidos para os vários grupos foram submetidos à análise de variância (ANOVA), seguidos pelos testes Student-Newman-Keuls, KruskalWallis e Mann-Whitney, quando necessário, utilizando o software SigmaStat versão 1.0 (Jadel Corporation). Para a densidade de volume, os testes estatísticos foram realizados após a transformação arco-seno dos dados originais, uma vez que estes valores, sendo porcentagens, podem não ter distribuição normal e, portanto, não serem passíveis de confronto por testes estatísticos que pressupõem normalidade das variáveis.

Após o valor médio das determinações de um dado grupo, foi indicado o desvio-padrão da média (DPM). 


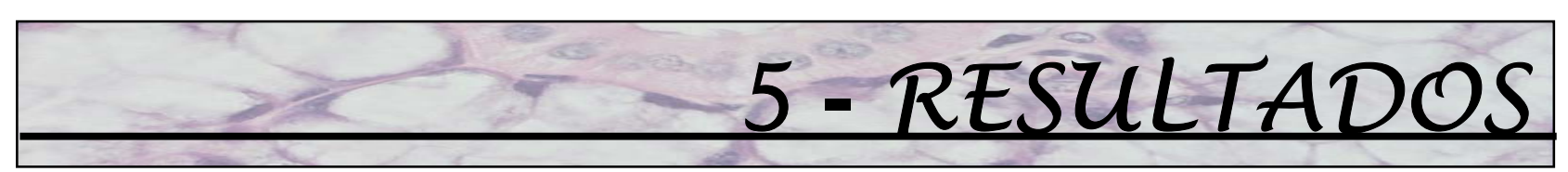




\section{5 - Resultados}

\subsection{RESULTADOS QUANTITATIVOS}

Em função de o projeto avaliar duas variáveis, ou seja, os intervalos post mortem e a variação do volume do fixador, os resultados foram divididos em parte $A$ e parte $B$, sendo a parte $A$, o estudo da evolução do processo de autólise nos diferentes períodos post mortem e a parte $B$, a interferência do volume de fixador neste processo.

PARTE A: Estudo da evolução do processo de autólise nos diferentes períodos

$$
\text { post mortem }
$$

\subsubsection{Dados ponderais}

\subsubsection{Dados ponderais de massa corporal}

Os valores individuais da massa corporal dos 25 animais do Grupo I, divididos nos períodos experimentais de Oh (subgrupo A), 3h (subgrupo B), 6h (subgrupo C), 12h (subgrupo D) e 24h (subgrupo E), encontram-se no Anexo 1, enquanto, as respectivas médias e desvios padrão estão apresentados na Tabela 1 e Figura12.

TABELA 1. Médias e desvios padrão da massa corporal (g) dos animais do Grupo I, nos diferentes períodos post mortem

\begin{tabular}{cccccc}
\hline & \multicolumn{5}{c}{ Massa corporal (g) } \\
\cline { 2 - 6 } & $\mathbf{0 h}$ & $\mathbf{3 h}$ & $\mathbf{6 h}$ & $\mathbf{1 2 h}$ & $\mathbf{2 4 h}$ \\
\hline Médias & 368,74 & 367,86 & 341,11 & 394,08 & 362,52 \\
DPM & $\pm 16,946$ & $\pm 19,385$ & $\pm 38,477$ & $\pm 37,998$ & $\pm 32,132$ \\
\cline { 2 - 5 } & Análise de Variância $(\mathrm{p}>0,05)$ & & & &
\end{tabular}




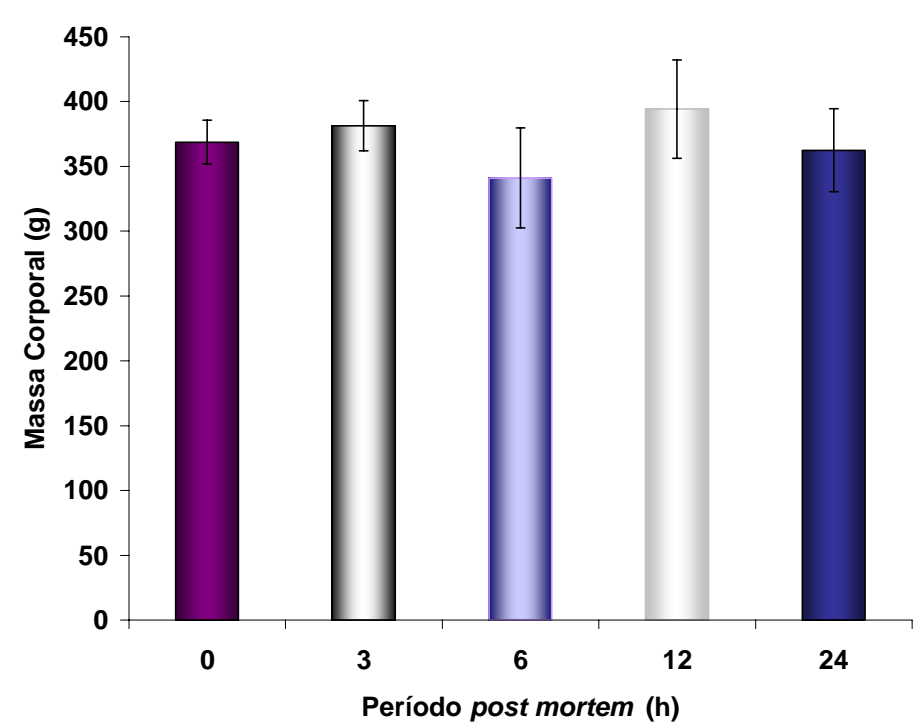

FIGURA 12. Distribuição das médias e desvios padrão da massa corporal (g) dos animais do Grupo I, nos diferentes períodos post mortem

A interpretação dos valores da Tabela 1 e da Figura 12 mostra pequenas diferenças entre os animais utilizados nos diferentes períodos de tempo post mortem. A análise dos dados mostrou que as diferenças não foram estatisticamente significantes $(p=0,145)$.

\subsubsection{Dados ponderais de massa glandular}

Os valores individuais da massa das glândulas sublinguais dos 25 animais do Grupo I, divididos nos períodos experimentais de Oh (subgrupo A), 3h (subgrupo B), 6h (subgrupo C), 12h (subgrupo D) e 24h (subgrupo E), encontramse no Anexo 2, enquanto, as respectivas médias e desvios padrão estão apresentados na Tabela 2 e Figura 13.

TABELA 2. Médias e desvios padrão da massa glandular (mg) das sublinguais dos animais do Grupo I, nos diferentes períodos post mortem

\begin{tabular}{cccccc}
\hline & \multicolumn{5}{c}{ Massa glandular $\mathbf{( m g )}$} \\
\cline { 2 - 6 } & $\mathbf{0 h}$ & $\mathbf{3 h}$ & $\mathbf{6 h}$ & $\mathbf{1 2 h}$ & $\mathbf{2 4 h}$ \\
\hline Médias & 73,23 & 79,58 & 92,39 & 90,98 & 98,37 \\
DPM & $\pm 7,664$ & $\pm 4,955$ & $\pm 6,565$ & $\pm 2,606$ & $\pm 10,871$
\end{tabular}

Análise de Variância $(p<0,05)$ 


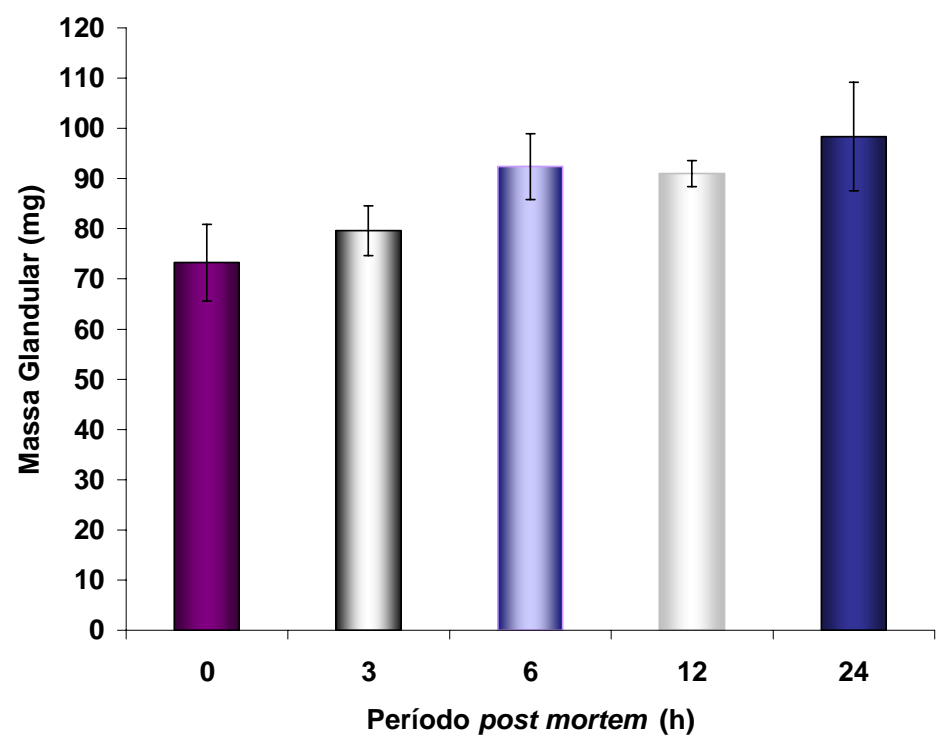

FIGURA 13. Distribuição das médias e desvios padrão da massa glandular (mg) das sublinguais dos animais do Grupo I, nos diferentes períodos post mortem

A interpretação dos valores da Tabela 2 e da Figura 13 mostra que, a massa das glândulas sublinguais aumentou 26,2\% ( $p<0,01)$ entre Oh e $6 \mathrm{~h}$ e manteve-se constante entre 6 e $24 h(p>0,05)$.

\subsubsection{Densidade glandular}

Os valores individuais da densidade das glândulas sublinguais dos 25 animais do Grupo II, divididos nos períodos experimentais de Oh (subgrupo A1), 3h (subgrupo B1), 6h (subgrupo C1), 12h (subgrupo D1) e 24h (subgrupo E1), encontram-se no Anexo 3, enquanto, as respectivas médias e desvio padrão estão apresentados na Tabela 3 e Figura 14.

TABELA 3. Médias e desvios padrão da densidade glandular $\left(\mathrm{mg} / \mathrm{cm}^{3}\right)$ das sublinguais dos animais do Grupo II, nos diferentes períodos post mortem

\begin{tabular}{cccccc}
\hline & \multicolumn{5}{c}{ Densidade da glândula (mg/cm $\mathbf{3})$} \\
\cline { 2 - 6 } & $\mathbf{0 h}$ & $\mathbf{3 h}$ & $\mathbf{6 h}$ & $\mathbf{1 2 h}$ & $\mathbf{2 4 h}$ \\
\hline Médias & 1,045 & 1,042 & 1,044 & 1,046 & 1,052 \\
DPM & $\pm 0,0133$ & $\pm 0,0032$ & $\pm 0,0043$ & $\pm 0,0006$ & $\pm 0,0091$ \\
\hline Kruskal Wallis $(\mathrm{p}>0,05)$ & & & &
\end{tabular}




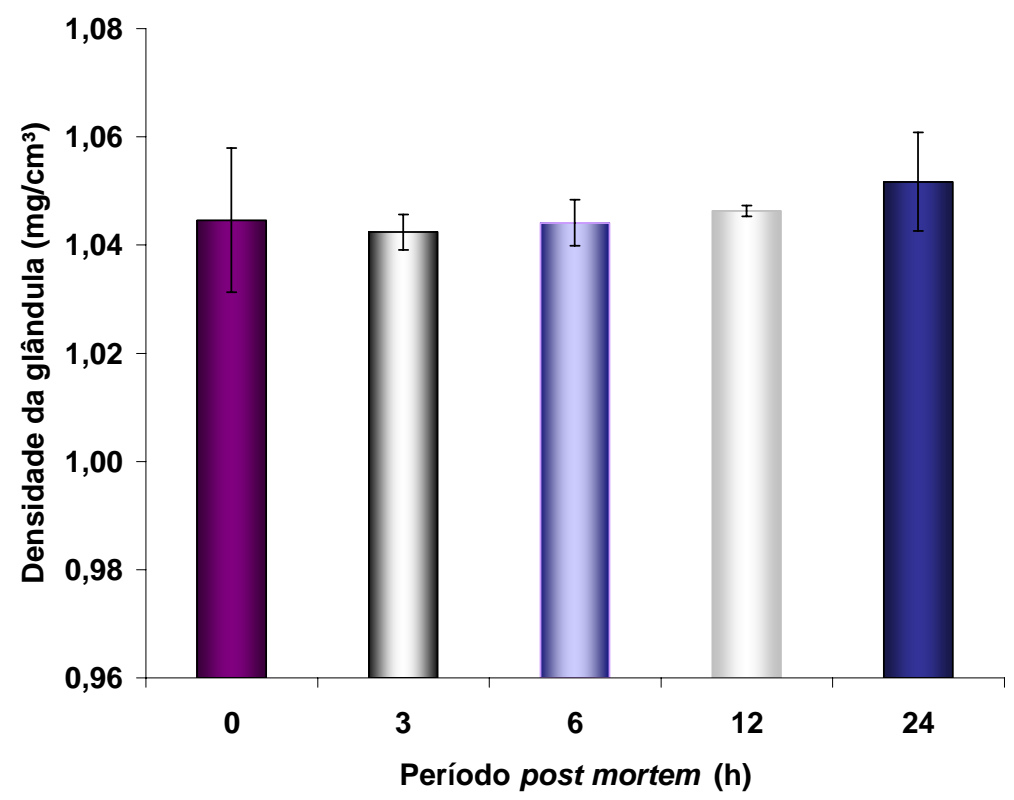

FIGURA 14. Distribuição das médias e desvios padrão da densidade das glândulas sublinguais $\left(\mathrm{mg} / \mathrm{cm}^{3}\right)$ dos animais do Grupo II, nos diferentes períodos post mortem

A interpretação dos valores da Tabela 3 e da Figura 14 mostra que a densidade das glândulas sublinguais não apresentou diferenças estatisticamente significantes entre os grupos estudados $(p=0,161)$, apresentando densidade média de $1,046 \mathrm{mg} / \mathrm{cm}^{3}$.

\subsubsection{Fator de retração}

Os valores individuais do fator de retração das glândulas sublinguais dos 25 animais do Grupo II, divididos nos períodos experimentais de Oh (subgrupo A1), 3h (subgrupo B1), 6h (subgrupo C1), 12h (subgrupo D1) e 24h (subgrupo E1), encontram-se no Anexo 4, enquanto, as respectivas médias e desvios padrão estão apresentados na Tabela 4 e Figura 15. 
TABELA 4. Médias e desvios padrão do fator de retração das glândulas sublinguais dos animais do Grupo II, nos diferentes períodos post mortem

\begin{tabular}{cccccc}
\hline & \multicolumn{5}{c}{ Fator de retração } \\
\cline { 2 - 6 } & $\mathbf{0 h}$ & $\mathbf{3 h}$ & $\mathbf{6 h}$ & $\mathbf{1 2 h}$ & $\mathbf{2 4 h}$ \\
\hline Médias & 0,673 & 0,611 & 0,582 & 0,636 & 0,622 \\
DPM & $\pm 0,0848$ & $\pm 0,0693$ & $\pm 0,0474$ & $\pm 0,0525$ & $\pm 0,0667$ \\
\cline { 2 - 6 } & & & & &
\end{tabular}

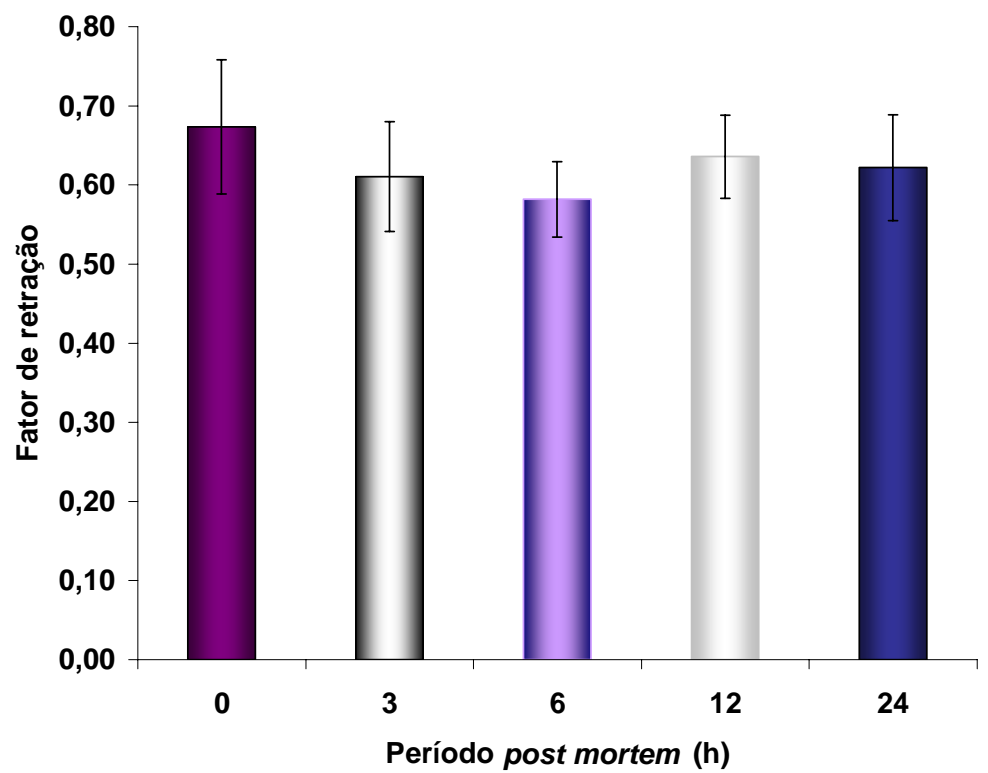

FIGURA 15. Distribuição das médias e desvios padrão do fator de retração das glândulas sublinguais dos animais do Grupo II, nos diferentes períodos post mortem

A interpretação dos valores da Tabela 4 e da Figura 15 mostra que, o fator de retração das glândulas sublinguais não apresentou diferenças estatisticamente significantes entre os grupos estudados $(p=0,297)$, apresentando fator de retração médio de 0,625. 


\subsubsection{Volume processado}

Os valores individuais do volume processado das glândulas sublinguais dos 25 animais do Grupo II, divididos nos períodos experimentais de Oh (subgrupo A1), 3h (subgrupo B1), 6h (subgrupo C1), 12h (subgrupo D1) e 24h (subgrupo E1), encontram-se no Anexo 5, enquanto, as respectivas médias e desvios padrão estão apresentados nas Tabelas 5 e Figura 16.

TABELA 5. Médias e desvios padrão do volume processado $\left(\mathrm{mm}^{3}\right)$ das glândulas sublinguais dos animais do Grupo II, nos diferentes períodos post mortem

\begin{tabular}{cccccc}
\hline & \multicolumn{5}{c}{ Volume Processado $\left(\mathbf{m m}^{\mathbf{3}}\right)$} \\
\cline { 2 - 6 } & $\mathbf{0 h}$ & $\mathbf{3 h}$ & $\mathbf{6 h}$ & $\mathbf{1 2 h}$ & $\mathbf{2 4 h}$ \\
\hline Médias & 47,199 & 46,625 & 51,472 & 55,284 & 58,168 \\
DPM & $\pm 4,9397$ & $\pm 2,9027$ & $\pm 3,6577$ & $\pm 1,5834$ & $\pm 6,4281$
\end{tabular}

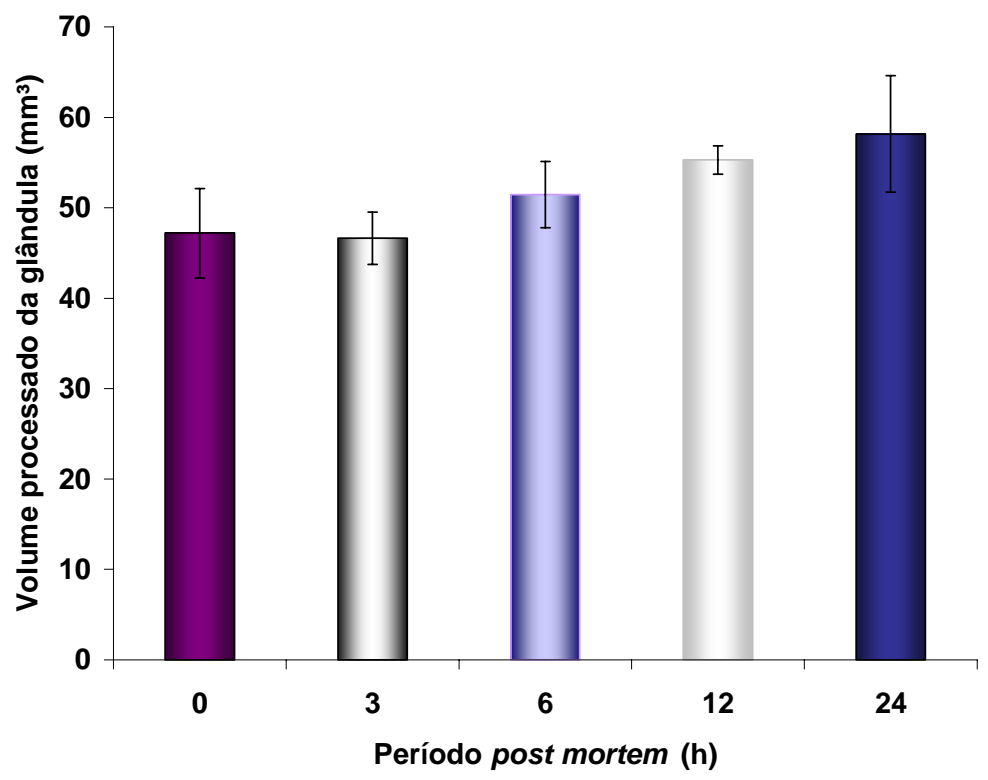

FIGURA 16. Distribuição das médias e desvios padrão do volume processado $\left(\mathrm{mm}^{3}\right)$ das glândulas sublinguais dos animais do Grupo II, nos diferentes períodos post mortem 
A interpretação dos valores da Tabela 5 e da Figura 16 mostra que, o volume processado da glândula sublingual aumentou 17,13\% $(p<0,01)$ entre Oh e 12h e manteve-se constante entre 12 e $24 h$ ( $p>0,05)$.

\subsubsection{Dados morfométricos}

\subsubsection{Densidade de volume (Vvi) de ácinos íntegros e autolisados}

Os valores da densidade de volume (Vvi) dos ácinos, ou seja, a porcentagem do volume glandular ocupada pelos ácinos, estimada através da volumetria de pontos (WEIBEL $\left.{ }^{43}, 1969\right)$, nos períodos experimentais de Oh (subgrupo A), 3h (subgrupo B), 6h (subgrupo C), 12h (subgrupo D) e 24h (subgrupo E), encontram-se no Anexo 6.

$\mathrm{Na}$ Tabela 6 e Figura 17 estão apresentados às médias e desvios padrão da densidade de volume de ácinos íntegros e autolisados dos 25 ratos do Grupo I, estudados segundo o período post mortem.

TABELA 6. Médias da densidade de volume de ácinos íntegros e autolisados dos animais do Grupo I, nos diferentes períodos post mortem

\begin{tabular}{|c|c|c|c|}
\hline \multirow[b]{2}{*}{ Grupos } & \multicolumn{3}{|c|}{ DENSIDADE DE VoLUME DE ÁcINOS (\%) } \\
\hline & ÍNTEGROS & AUTOLISADOS & TOTAL \\
\hline & MÉDIAS & MÉDIAS & MÉDIAS \\
\hline Oh & $70,00 \pm 3,045$ & $0,32 \pm 0,311$ & $70,32 \pm 3,082$ \\
\hline $3 h$ & $72,02 \pm 3,084$ & $2,05 \pm 1,396$ & $74,07 \pm 3,378$ \\
\hline $6 h$ & $36,57 \pm 13,851$ & $35,33 \pm 14,586$ & $71,90 \pm 2,960$ \\
\hline $12 \mathrm{~h}$ & $4,03 \pm 2,577$ & $68,51 \pm 4,749$ & $72,54 \pm 4,129$ \\
\hline $24 \mathrm{~h}$ & $0,00 \pm 0,000$ & $75,16 \pm 3,956$ & $75,16 \pm 3,957$ \\
\hline
\end{tabular}

Teste de Student-Newman-Keuls $(p<0,05)$ 


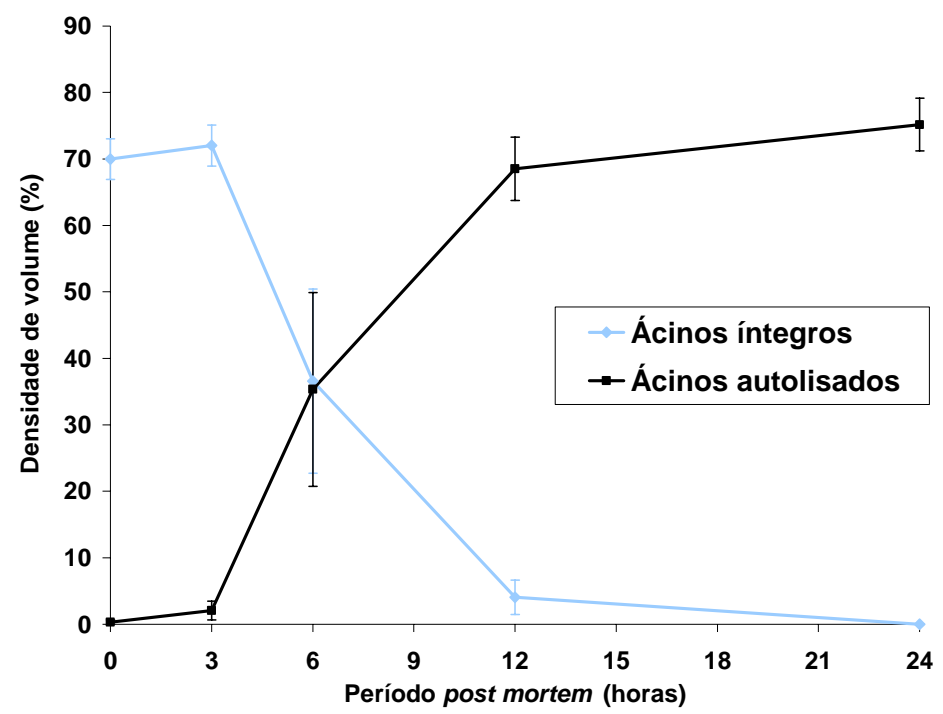

FIGURA 17. Distribuição das médias da densidade de volume de ácinos íntegros e autolisados dos animais do Grupo I, nos diferentes períodos post mortem

A interpretação dos valores da Tabela 6 e da Figura 17 mostra que, a densidade de volume dos ácinos íntegros das glândulas sublinguais diminuiu com o aumento do período post mortem, sendo inversamente proporcional ao aumento da densidade de volume dos ácinos autolisados. A análise estatística da evolução da densidade de volume dos ácinos autolisados mostrou uma diferença significante entre todos os períodos estudados $(p<0,05)$, sendo que, no período de 3 horas apenas $2,7 \%$ dos ácinos estavam autolisados, aumentando significantemente $17 x$, entre 3 e 6 horas, representando $47 \%$ do volume total de ácinos. Entre 6 e 12 horas aumentou significativamente 2x, representando 91\% do volume total de ácinos. Às 24 horas 100\% dos ácinos estavam autolisados.

\subsubsection{Volume absoluto (Vt) de ácinos íntegros e autolisados}

O volume absoluto (Vt) dos ácinos íntegros e autolisados, nos períodos experimentais de Oh (subgrupo A), 3h (subgrupo B), 6h (subgrupo C), 12h (subgrupo D) e 24h (subgrupo E), encontra-se no Anexo 7.

$\mathrm{Na}$ Tabela 7 e Figura 18 estão apresentados as médias e desvios padrão do volume absoluto de ácinos íntegros e autolisados dos 25 ratos do Grupo I, estudados segundo o período post mortem. 
TABELA 7. Médias do volume absoluto (Vt) de ácinos íntegros e autolisados dos animais do Grupo I, nos diferentes períodos post mortem

\begin{tabular}{|c|c|c|c|}
\hline \multirow[b]{2}{*}{ Grupos } & \multicolumn{3}{|c|}{ Volume ABSOLUTO de Ácinos ( $\left.\mathrm{MM}^{3}\right)$} \\
\hline & ÍNTEGROS & AUTOLISADOS & TOTAL \\
\hline & MÉDIAS & MÉDIAS & MÉDIAS \\
\hline Oh & $33,00 \pm 3,324$ & $0,14 \pm 0,136$ & $33,14 \pm 3,244$ \\
\hline $3 h$ & $33,58 \pm 2,498$ & $0,92 \pm 0,581$ & $34,50 \pm 2,092$ \\
\hline $6 h$ & $19,04 \pm 8,001$ & $17,94 \pm 6,999$ & $36,98 \pm 2,669$ \\
\hline $12 \mathrm{~h}$ & $2,22 \pm 1,436$ & $37,91 \pm 3,381$ & $40,14 \pm 3,106$ \\
\hline $24 h$ & - & $43,78 \pm 6,069$ & $43,78 \pm 6,069$ \\
\hline
\end{tabular}

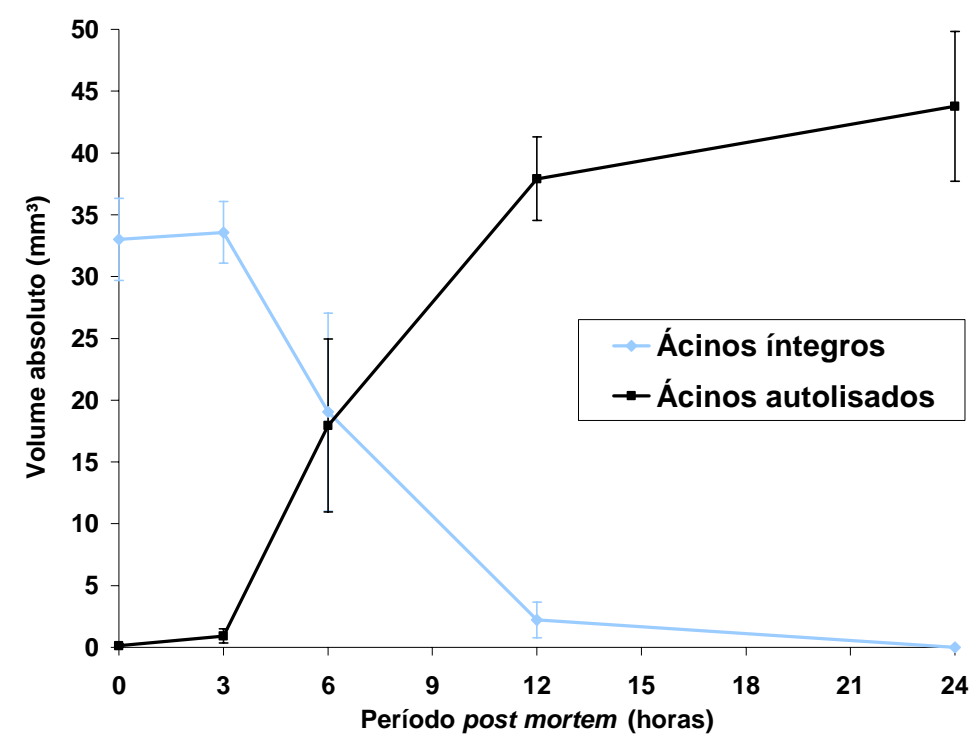

FIGURA 18. Distribuição das médias do volume absoluto $(\mathrm{Vt})$ de ácinos íntegros e autolisados dos animais do Grupo I, nos diferentes períodos post mortem

A interpretação dos valores da Tabela 7 e da Figura 18 mostra que, não houve diferenças estatisticamente significantes no volume absoluto dos ácinos íntegros entre 0 e 3 horas $(p>0,05)$. Entre $3 \mathrm{~h}$ e $12 \mathrm{~h}$ houve uma diminuição altamente significante de $93 \%(p<0,01)$, às 24 horas desaparecendo totalmente. $A$ evolução do volume dos ácinos autolisados foi inversamente proporcional ao dos ácinos íntegros. 


\subsubsection{Cálculo do coeficiente de variação ("erro")}

O grau de precisão da estimativa da densidade de volume dos ácinos foi avaliado através do cálculo do coeficiente de variação ("erro"), da proporção em estudo.

Os coeficientes de variação obtidos para os 25 ratos quantificados, do Grupo I, estão no Anexo 8. Na tabela 8 estão apresentadas as médias do coeficiente de variação dos ácinos íntegros e autolisados do grupo I, estudados segundo o período post mortem de cada grupo.

TABELA 8. Coeficiente de variação médio para os ácinos íntegros e autolisados no Grupo I, nos diferentes períodos post mortem

\begin{tabular}{ccc}
\hline \multirow{2}{*}{ Grupos } & \multicolumn{2}{c}{ CoEFICIENTE de VARIAÇÃo - ERRo (\%) } \\
\cline { 2 - 3 } & ÍnTEGROS & AutOLISADOS \\
\cline { 2 - 3 } & MÉdIAS & MÉDIAS \\
\hline $\mathbf{0 h}$ & 0,92 & 19,69 \\
$\mathbf{3 h}$ & 0,87 & 11,38 \\
$\mathbf{6 h}$ & 1,98 & 1,99 \\
$\mathbf{1 2 h}$ & 8,43 & 0,91 \\
$\mathbf{2 4 h}$ & - & 0,81 \\
\hline
\end{tabular}

PARTE B: Estudo da Interferência do volume de fixador no processo de autólise.

\subsubsection{Dados ponderais}

\subsubsection{Dados ponderais de massa corporal}

Os valores individuais da massa corporal dos 10 animais do grupo onde houve a variação de volume do líquido fixador, no período de 0 hora, encontramse no Anexo 9, enquanto, as respectivas médias e desvios padrão estão apresentados na Tabela 9 e Figura 19. 
TABELA 9. Médias e desvios padrão da massa corporal (g) dos animais dos grupos onde houve variação de volume do fixador

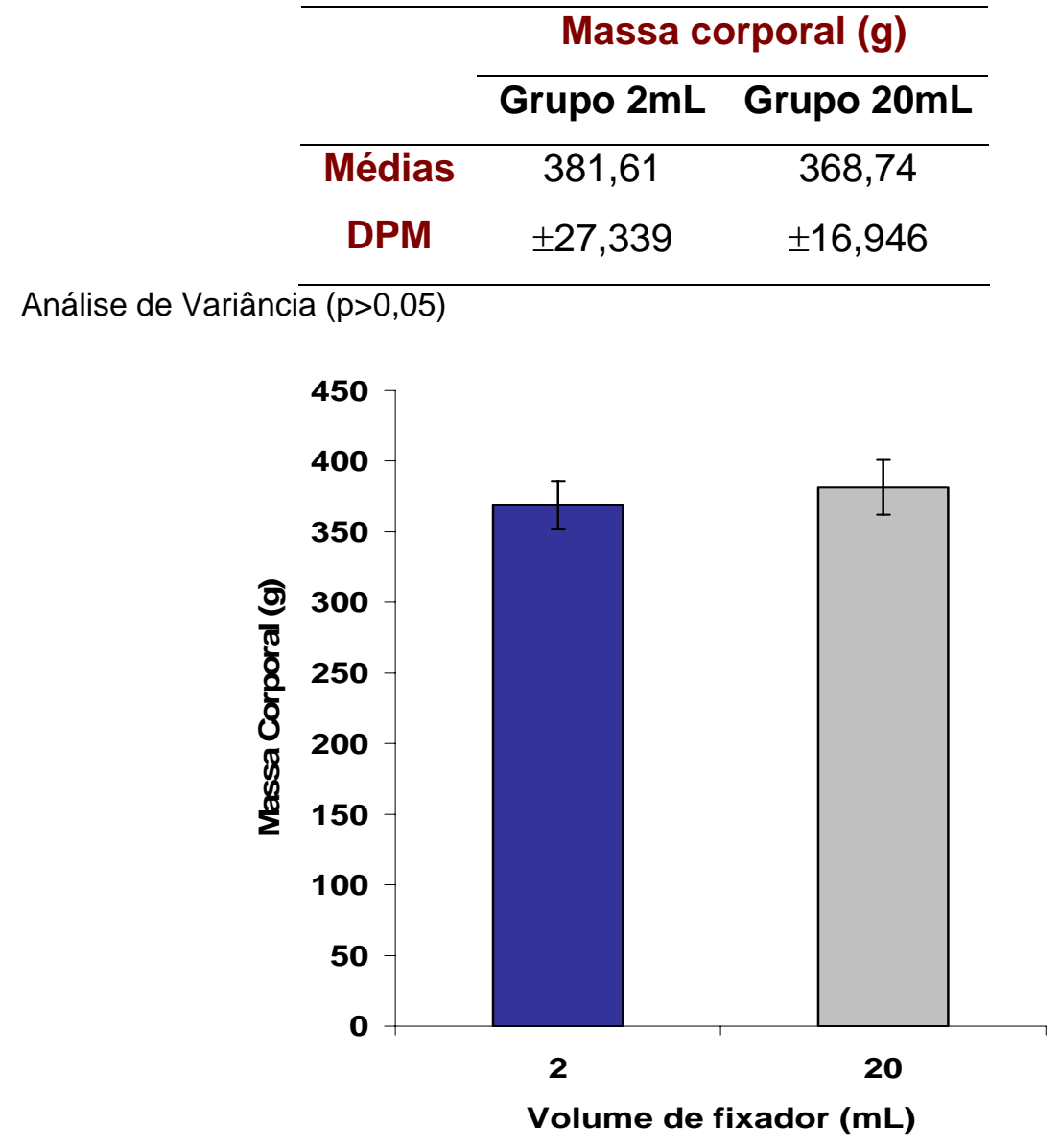

FIGURA 19. Distribuição das médias e desvios padrão da massa corporal (g) dos animais dos grupos onde houve variação de volume do líquido fixador

A interpretação dos valores da Tabela 9 e da Figura 19 mostra que, a massa corporal dos ratos estudados não apresentou diferenças estatisticamente significantes entre os grupos estudados $(p=0,3969)$.

\subsubsection{Dados ponderais de massa glandular}

Os valores individuais da massa glandular dos 10 animais do grupo onde houve a variação de volume do líquido fixador, no período de 0 hora, encontram-se no Anexo 10, enquanto, as respectivas médias e desvios padrão estão apresentados na Tabela 10 e Figura 20. 
TABELA 10. Médias e desvios padrão da massa glandular (mg) da sublingual dos animais dos grupos onde houve variação de volume do líquido fixador

\begin{tabular}{ccc}
\hline & \multicolumn{2}{c}{ Massa glandular (mg) } \\
\cline { 2 - 3 } & Grupo 2mL & Grupo 20mL \\
\hline Médias & 85,25 & 73,23 \\
DPM & $\pm 4,578$ & $\pm 7,664$
\end{tabular}

Análise de Variância $(p<0,05)$

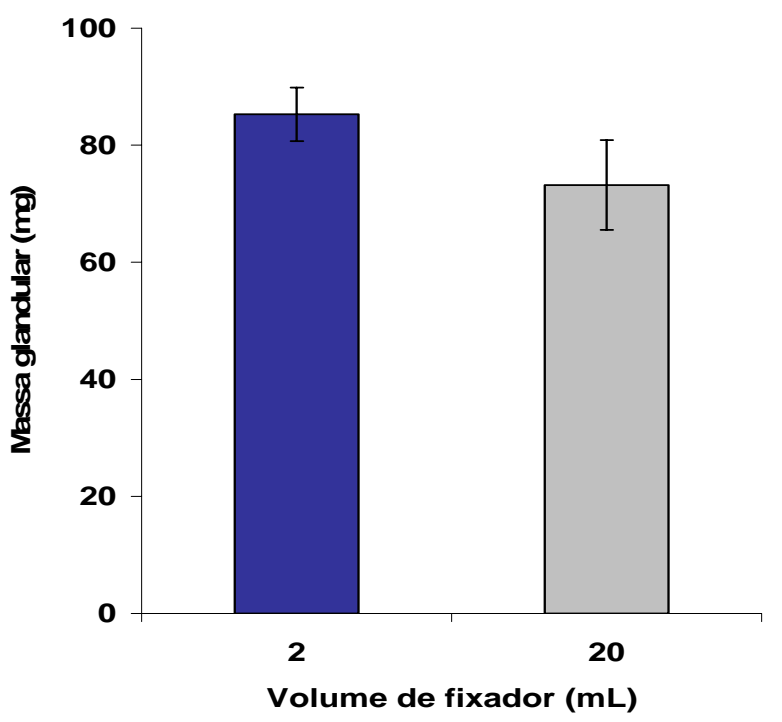

FIGURA 20. Distribuição das médias e desvios padrão da massa glandular (mg) da sublingual dos animais dos grupos onde houve variação de volume do líquido fixador

A interpretação dos valores da Tabela 10 e da Figura 20 mostra que, a massa das glândulas sublinguais do grupo de $2 \mathrm{~mL}$ foi $16,4 \%(p<0,05)$ maior em relação as glândulas do grupo de $20 \mathrm{~mL}$. 


\subsubsection{Densidade glandular}

Os valores individuais da densidade da glândula sublingual dos 10 animais do grupo onde houve a variação de volume do líquido fixador, no período experimental de 0h, encontram-se no Anexo 11, enquanto, as respectivas médias e desvio padrão estão apresentados na Tabela 11 e Figura 21.

TABELA 11. Médias e desvios padrão da densidade glandular $\left(\mathrm{mg} / \mathrm{cm}^{3}\right)$ das sublinguais dos animais dos grupos onde houve variação de volume do líquido fixador

\begin{tabular}{|c|c|c|}
\hline & \multicolumn{2}{|c|}{$\begin{array}{c}\text { Densidade da glândula } \\
\qquad\left(\mathrm{mg} / \mathrm{cm}^{3}\right)\end{array}$} \\
\hline & Grupo 2mL & Grupo 20mL \\
\hline Médias & 1,047 & 1,045 \\
\hline DPM & $\pm 0,0090$ & $\pm 0,0133$ \\
\hline
\end{tabular}

Análise de Variância $(p>0,05)$

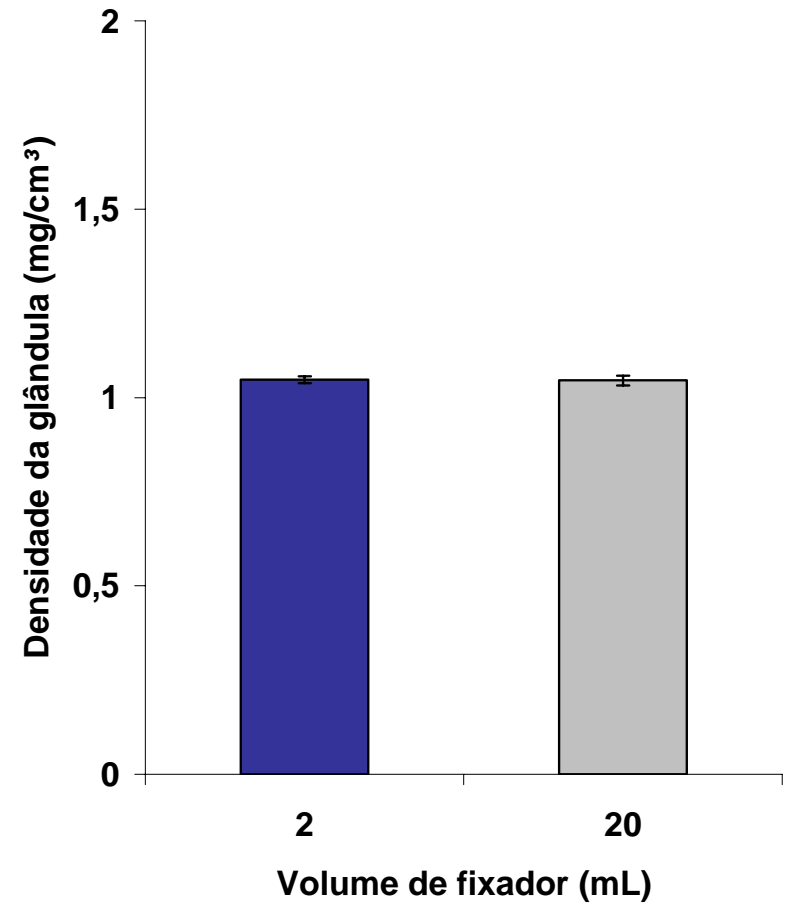

FIGURA 21. Distribuição das médias e desvios padrão (DPM) da densidade das glândulas sublinguais $\left(\mathrm{mg} / \mathrm{cm}^{3}\right)$ dos animais dos grupos onde houve variação de volume do líquido fixador 
A interpretação dos valores da Tabela 11 e da Figura 21 mostra que, a densidade da glândula sublingual não apresentou diferença estatisticamente significante entre os grupos estudados ( $p=0,776)$, apresentando densidade média de $1,046 \mathrm{mg} / \mathrm{cm}^{3}$.

\subsubsection{Fator de retração}

Os valores individuais do fator de retração da glândula sublingual dos 10 animais do grupo onde houve a variação de volume do líquido fixador, no período experimental de 0h, encontram-se no Anexo 12, enquanto, as respectivas médias e desvios padrão, estão apresentados na Tabela 12 e Figura 22.

TABELA 12. Médias e desvios padrão do fator de retração das glândulas sublinguais dos animais dos grupos onde houve variação de volume do líquido fixador

\begin{tabular}{ccc}
\hline & \multicolumn{2}{c}{ Fator de retração } \\
\cline { 2 - 3 } & Grupo 2mL & Grupo 20mL \\
\hline Médias & 0,597 & 0,673 \\
DPM & $\pm 0,0703$ & $\pm 0,0848$ \\
\hline
\end{tabular}

Análise de Variância $(p>0,05)$

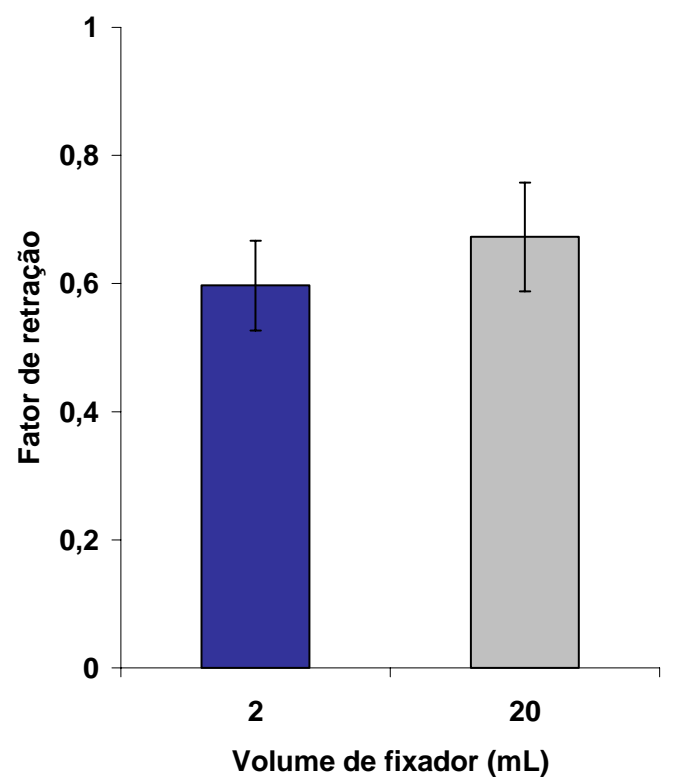

FIGURA 22. Distribuição das médias e desvios padrão do fator de retração das glândulas sublinguais dos animais dos grupos onde houve variação de volume do líquido fixador 
A interpretação dos valores da Tabela 12 e da Figura 22 mostra que, o fator de retração da glândula sublingual não apresentou diferença estatisticamente significante entre os grupos estudados $(p=0,162)$, apresentando fator de retração médio de 0,635.

\subsubsection{Volume processado}

Os valores individuais do volume processado da glândula sublingual dos 10 animais do grupo onde houve a variação de volume do líquido fixador, no período experimental de 0h, encontram-se no Anexo 13, enquanto, as respectivas médias e desvios padrão, estão apresentados na Tabela 13 e Figura 23.

TABELA 13. Médias e desvios padrão do volume processado $\left(\mathrm{mm}^{3}\right)$ das glândulas sublinguais dos animais dos grupos onde houve variação de volume do líquido fixador

\begin{tabular}{ccc}
\cline { 2 - 3 } & \multicolumn{2}{c}{ Volume processado $\left(\mathrm{mm}^{3}\right)$} \\
\cline { 2 - 3 } & Grupo 2mL & Grupo 20mL \\
\cline { 2 - 3 } Médias & 48,641 & 47,199 \\
DPM & $\pm 2,6120$ & $\pm 4,9397$
\end{tabular}

Análise de Variância $(p>0,05)$

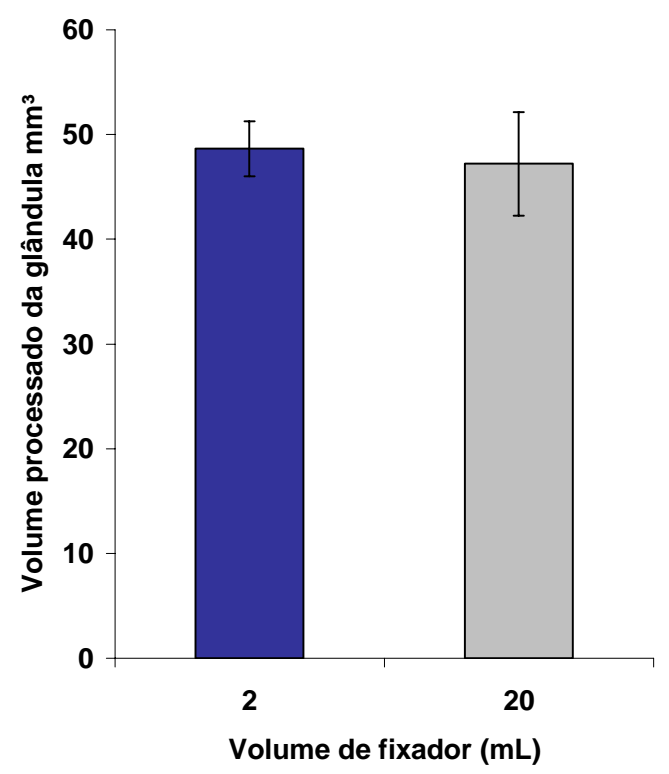

FIGURA 23. Distribuição das médias e desvios padrão do volume processado $\left(\mathrm{mm}^{3}\right)$ das glândulas sublinguais dos animais dos grupos onde houve variação de volume do líquido fixador 
A interpretação dos valores da Tabela 13 e da Figura 23 mostra que, o volume processado da glândula não apresentou diferença estatisticamente significante entre os grupos estudados $(p=0,580)$, apresentando volume processado médio de 47,92.

\subsubsection{Dados morfométricos}

\subsubsection{Densidade de volume (Vvi) de ácinos íntegros e autolisados}

Os valores das densidades de volume ( $\mathrm{Vvi}$ ) individuais obtidas nos grupos 2mL e 20mL de líquido fixador, encontram-se no Anexo 14.

$\mathrm{Na}$ Tabela 14 estão apresentados as médias e desvios padrão da densidade de volume de ácinos íntegros e autolisados dos ratos estudados segundo a quantidade de líquido fixador utilizado.

TABELA 14. Médias da densidade de volume de ácinos íntegros e autolisados nos grupos estudados que variam na quantidade de líquido fixador

\begin{tabular}{|c|c|c|c|}
\hline \multirow[b]{2}{*}{ Grupos } & \multicolumn{3}{|c|}{ DENSIDADE DE VoLUME de ÁcINOS (\%) } \\
\hline & ÍNTEGROS & AutOLISADOS & TOTAL \\
\hline & MÉdIAS & MÉDIAS & MÉDIAS \\
\hline $2 \mathrm{~mL}$ & $74,83 \pm 0,022$ & $0,63 \pm 0,012$ & $75,28 \pm 0,012$ \\
\hline $20 \mathrm{~mL}$ & $70,00 \pm 0,030$ & $0,32 \pm 0,003$ & $70,32 \pm 0,031$ \\
\hline
\end{tabular}

A interpretação dos valores da Tabela 14 mostra que, a densidade de volume dos ácinos íntegros, autolisados e total da glândula sublingual não se alteraram com a variação da quantidade de líquido fixador $(p=0,690)$. 


\subsubsection{Volume absoluto dos ácinos íntegros e autolisados}

Os valores do volume absoluto $(\mathrm{Vt})$ da glândula sublingual dos 10 animais do grupo onde houve a variação de volume do líquido fixador, no período experimental de Oh, encontram-se no Anexo 15. Enquanto, as respectivas médias e desvios padrão, estão apresentados na Tabela 15.

TABELA 15. Médias do volume absoluto de ácinos íntegros e autolisados dos animais dos grupos estudados que variam na quantidade de líquido fixador

\begin{tabular}{cccc}
\hline \multirow{2}{*}{ Grupos } & \multicolumn{3}{c}{ Volume Absoluto de Ácinos $\left(\mathrm{MM}^{3}\right)$} \\
\cline { 2 - 4 } & ÍNTEGROS & AutOlisAdOS & TotAL \\
\cline { 2 - 4 } $2 \mathbf{m L}$ & $36,39 \pm 2,040$ & $0,31 \pm 0,593$ & $36,70 \pm 1,909$ \\
$\mathbf{2 0 m L}$ & $33,00 \pm 3,324$ & $0,14 \pm 0,136$ & $33,14 \pm 3,244$
\end{tabular}

Análise de Variância $(p>0,05)$

A interpretação dos valores da Tabela 15 mostra que, não houve diferença estatisticamente significante no volume absoluto dos ácinos íntegros $(p=0,0878)$, ácinos autolisados $(p=0,555)$ e ácinos totais $(p=0,0675)$.

\subsubsection{Cálculo do coeficiente de variação ("erro")}

Os valores dos coeficientes de variação obtidos para os animais dos grupos $2 \mathrm{~mL}$ e $20 \mathrm{~mL}$ de fixador, encontram-se no Anexo 16 e suas médias, estão apresentados na Tabela 16. 
TABELA 16. Coeficiente médio de variação dos ácinos íntegros e autolisados no grupo utilizado para avaliar a variação de volume de formol

\begin{tabular}{|c|c|c|}
\hline \multirow{3}{*}{ Grupos } & \multicolumn{2}{|c|}{ COEFICIENTE DE VARIAÇÃO - ERRO (\%) } \\
\hline & ÍNTEGROS & AUTOLISADOS \\
\hline & MÉdIAS & MÉDIAS \\
\hline $2 \mathrm{~mL}$ & 0,81 & 6,31 \\
\hline $20 \mathrm{~mL}$ & 0,92 & 11,81 \\
\hline
\end{tabular}

\subsection{RESULTADOS QUALITATIVOS}

PARTE A: Estudo da evolução do processo de autólise nos diferentes períodos post mortem

As glândulas sublinguais coletadas imediatamente após o sacrifício dos animais (Figuras 24 e 25) mostraram-se íntegras com ácinos mucosos, mistos e ductos intralobulares e interlobulares entremeados por uma pequena quantidade de tecido conjuntivo. Os ácinos mistos apresentaram células mucosas volumosas, bem delimitadas, com citoplasma abundante e núcleo de perfil elíptico, enquanto que, as células serosas em forma de semiluas localizavam-se na porção periférica dos ácinos, exibindo pequeno citoplasma eosinofílico e núcleo esférico ocupando a região central.

As glândulas dos animais com 3 horas post mortem (Figuras 26 e 27) apresentaram sinais iniciais de degeneração dos ácinos com, algumas células mucosas apresentando granulações, espaços irregulares no citoplasma e perda da sua integridade, facilmente observada pela descoloração do seu limite externo formando borrões. As células serosas mostraram-se similares às do período de 0 hora post mortem. Já, os ductos estriados e excretores exibiram estágio avançado de autólise com completa desorganização das estruturas celulares decorrente do rompimento de membrana celular e do extravasamento do material citoplasmático e do núcleo para o interior da luz do ducto. 
Ás 6 horas post mortem (Figuras 28 e 29), as glândulas exibiram inúmeras células acinosas mucosas em estágio inicial de autólise com perda da sua integridade, formação de granulações no interior do citoplasma e cariorrexe, ou seja, núcleo com distribuição irregular da cromatina, formando grumos na sua periferia, além da perda dos limites nucleares. As células serosas exibiram aumento do volume citoplasmático com formação de pequenas granulações no citoplasma e cariorrexe. Os ductos e o estroma apresentavam características morfológicas similares aos de 3 horas post mortem.

Nas glândulas sublinguais de 12 horas post mortem (Figuras 30, 31, 32 e 33) quase que a totalidade dos ácinos apresentaram estágios intermediários de autólise, com limites ainda definidos. As células mucosas, exibiam perda parcial ou completa do seu limite externo, desorganização do citoplasma, com alguns núcleos em cariorrexe e vários núcleos picnóticos, e hipercromáticos devido à alta condensação da cromatina. As semiluas serosas, os ductos e o estroma apresentavam características similares ao período de 6 horas post mortem.

No período de 24 horas post mortem (Figuras 34, 35, 36 e 37), os ácinos exibiram estágio avançado de autólise com áreas onde os limites dos ácinos foram mantidos e outras onde ocorreu o seu rompimento completo com todo o conteúdo citoplasmático e os núcleos picnóticos dispersos. Neste caso, os ácinos serosos ainda mantinham o seu limite externo íntegro podendo ser facilmente destacados na massa amorfa de células mucosas destruídas. Devido ao elevado grau de autólise das estruturas glandulares era difícil distinguir o parênquima do estroma.

PARTE B: Estudo da Interferência do volume de fixador no processo de autólise.

Os dados quantitativos acusaram ácinos com autólise apesar de valores não significantes estatisticamente (Tabelas 14 e 15). Qualitativamente, os achados de autólise naqueles ácinos eram descritos não passando de um desaparecimento parcial de limites celulares das células acinares, com distribuição variada entre ácinos periféricos e centrais. Os detalhes assinalados pelas setas 
azuis da Figura 27 ilustram os referidos achados por serem idênticos aos do período de 3 horas. 


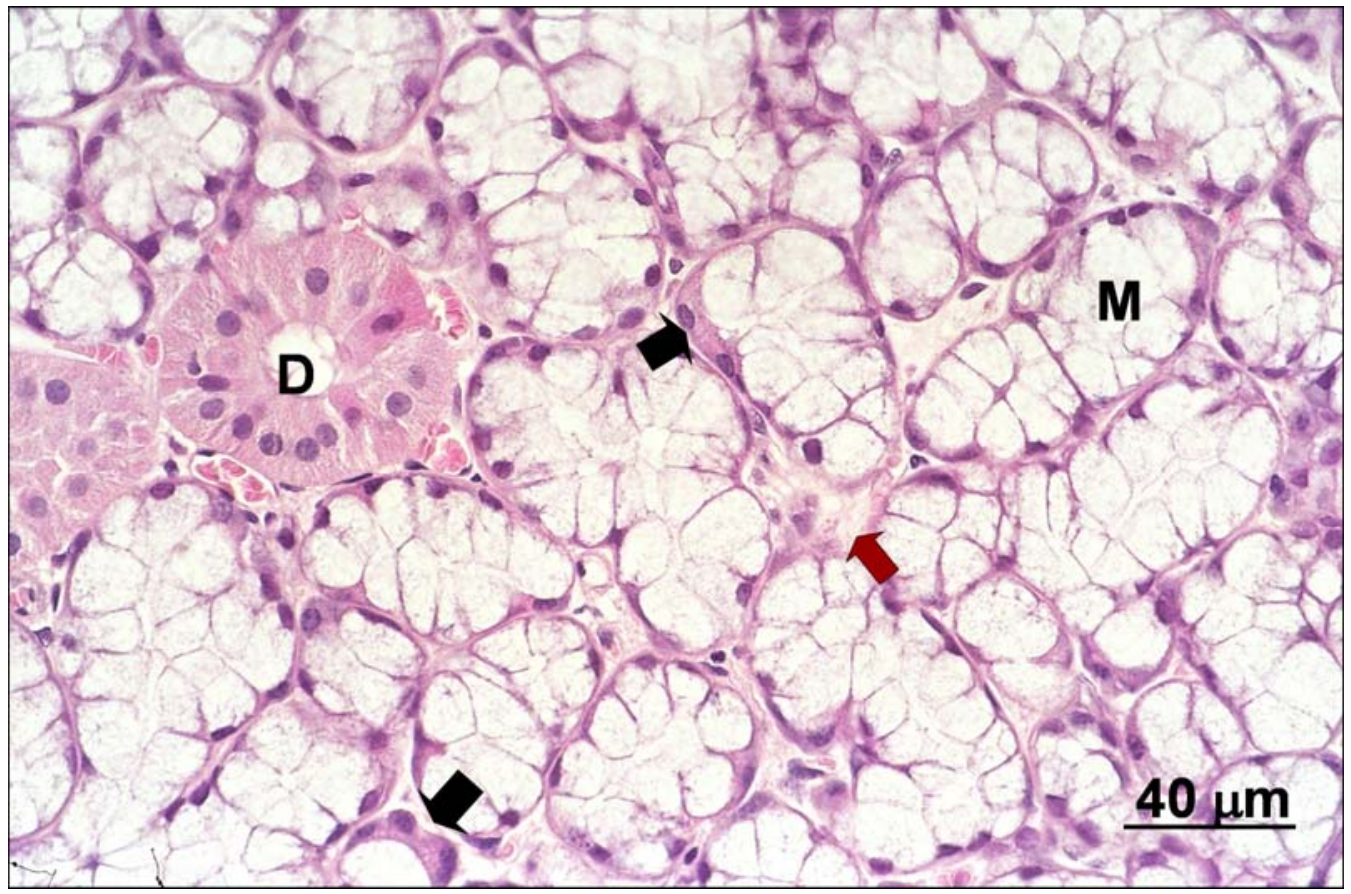

FIGURA 24. Foto micrografia da glândula sublingual coletada as 0 hora: aspecto panorâmico. Observar a integridade da estrutura glandular, exibindo ácinos mistos com células mucosas (M) volumosas e pequenas semiluas serosas (seta cheia) e ductos intralobulares (D) entremeados pelo estroma (seta vermelha). HE

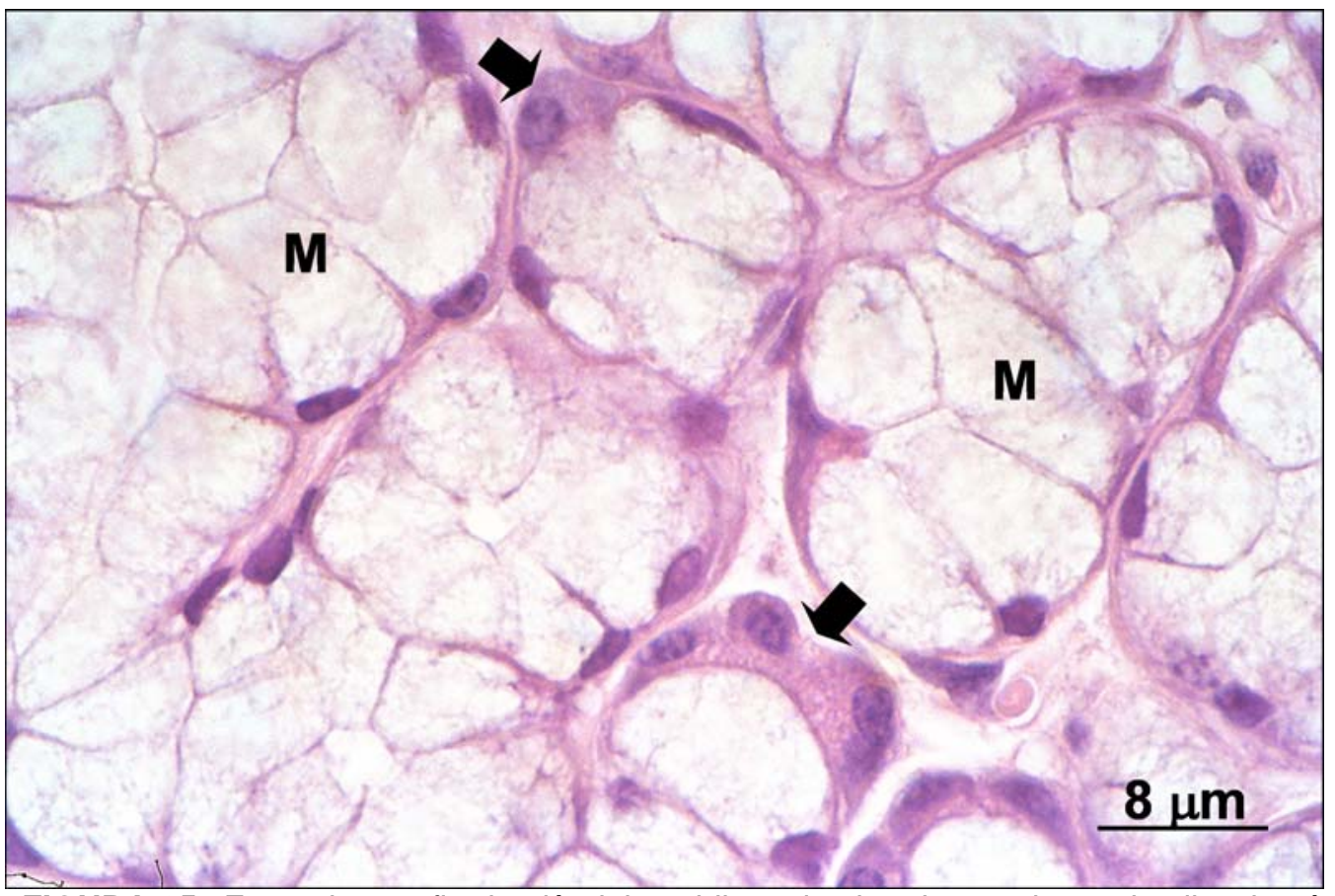

FIGURA 25. Foto micrografia da glândula sublingual coletada as 0 hora: detalhe dos ácinos mistos exibindo células mucosas $(\mathrm{M})$ bem delimitadas com citoplasma abundante e núcleo elíptico, ocupando a porção supra basal da célula e semiluas serosas (seta cheia) com células serosas contendo pouco citoplasma e núcleo elíptico, ocupando a porção central da célula. HE 


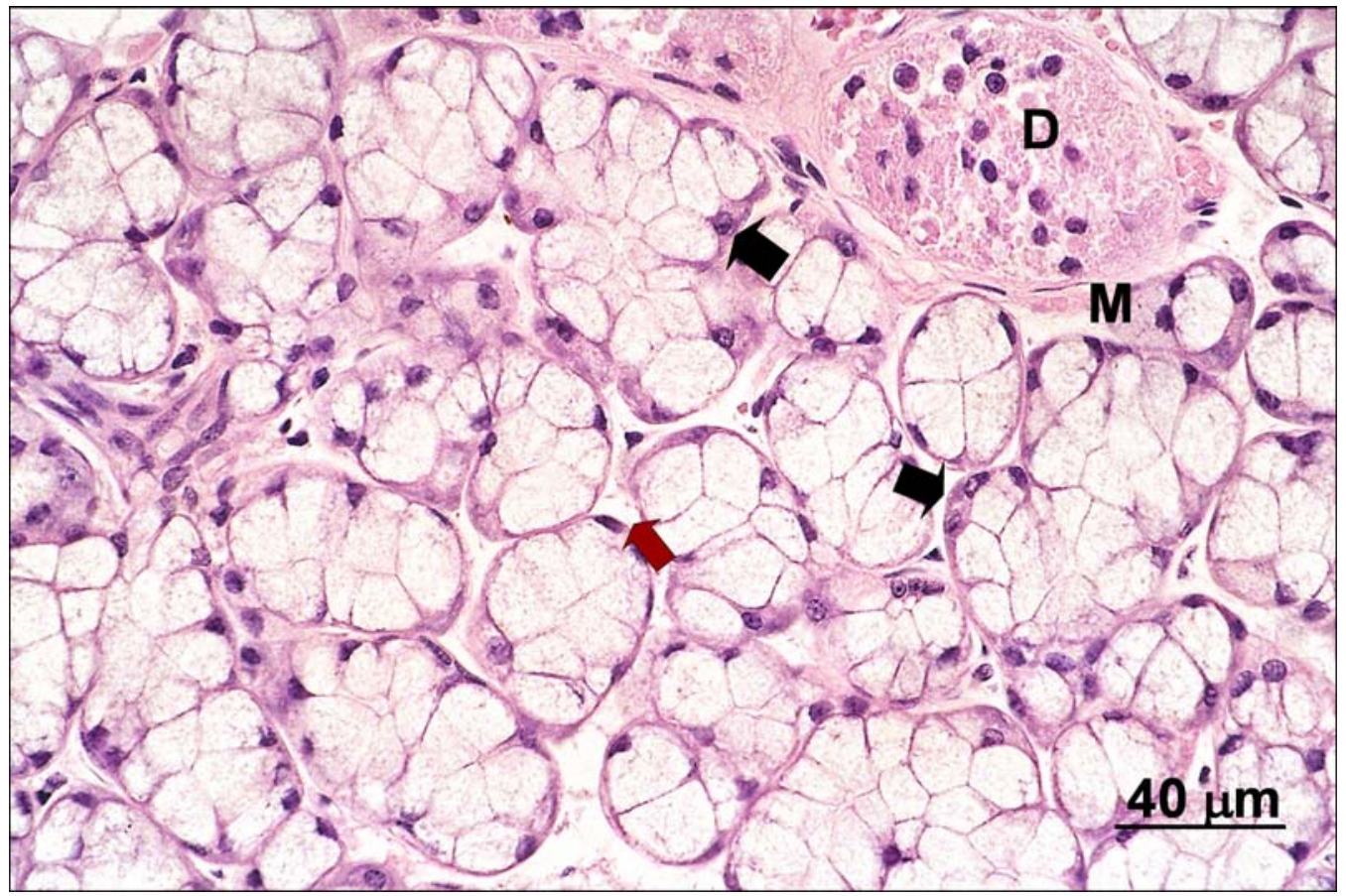

FIGURA 26. Foto micrografia da glândula sublingual coletada às 3 horas: aspecto panorâmico. Observar a aparente integridade da estrutura glandular, exibindo ácinos mistos com células mucosas (M) volumosas e pequenas semiluas serosas (seta cheia) e ductos intralobulares (D) entremeados pelo estroma (seta vermelha). HE

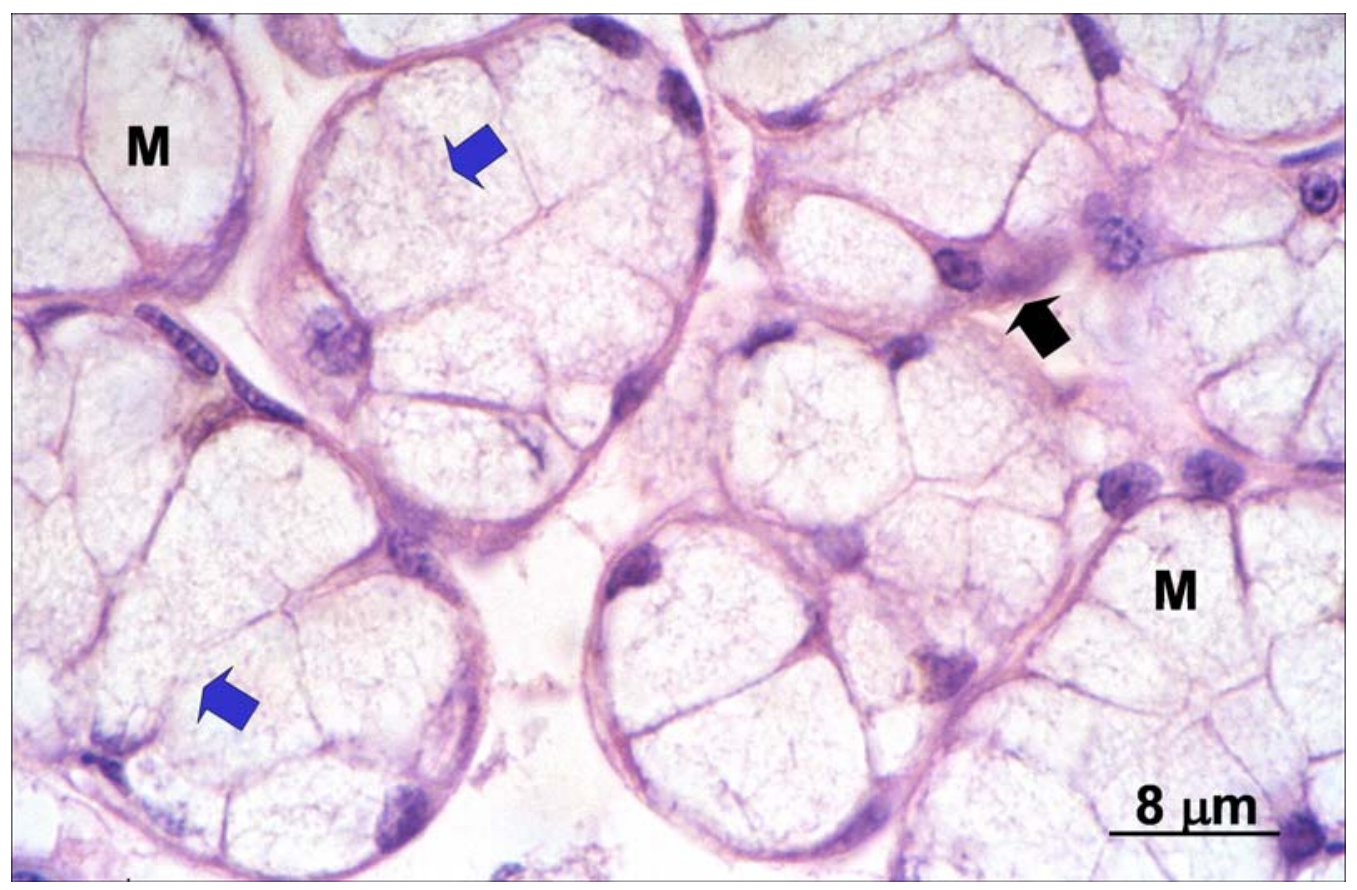

FIGURA 27. Foto micrografia da glândula sublingual coletada às 3 horas: detalhe dos ácinos mistos exibindo algumas células mucosas (M) com perda da integridade do seu limite externo (seta azul) e células serosas íntegras (seta cheia). HE 


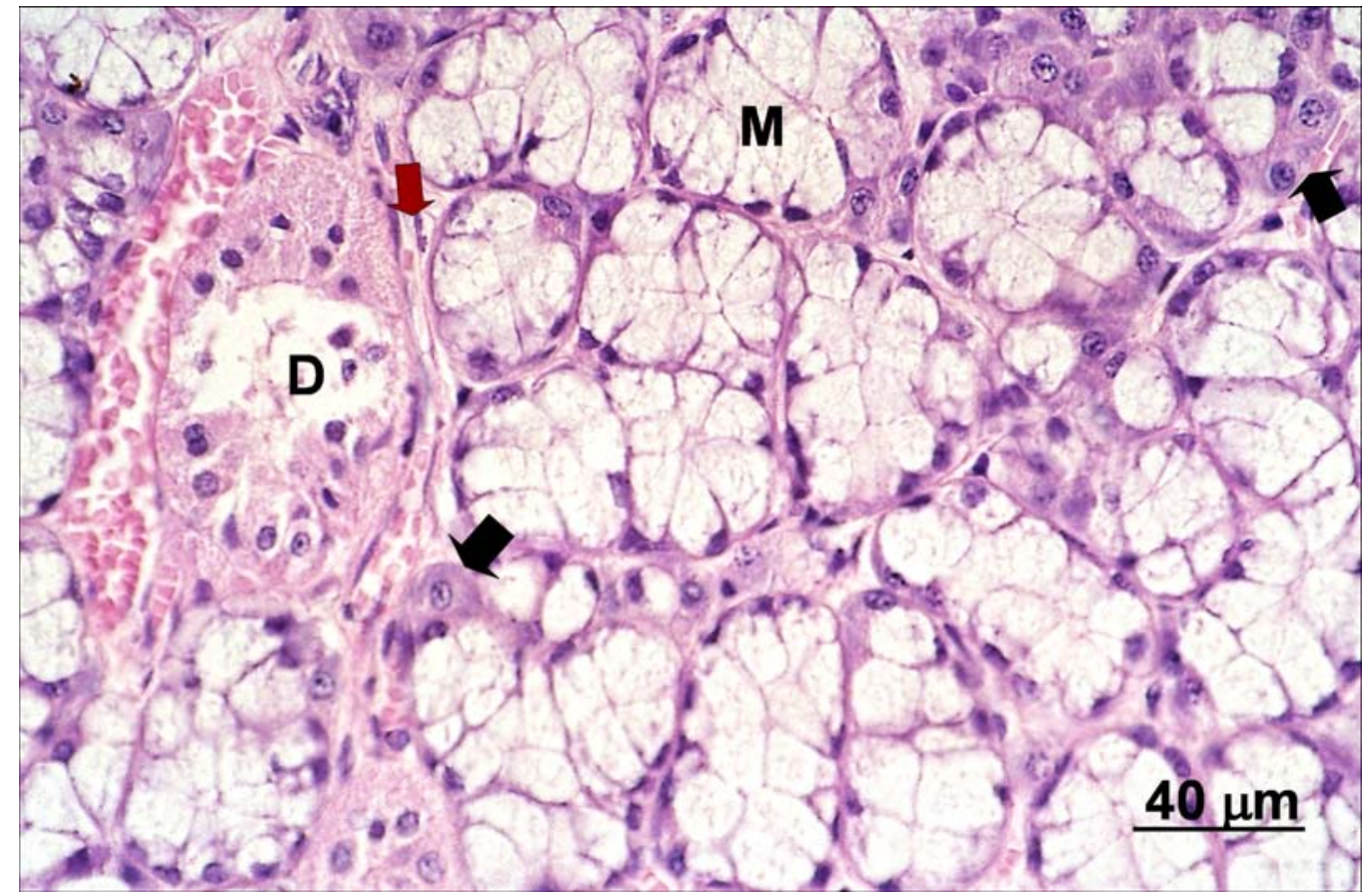

FIGURA 28. Foto micrografia da glândula sublingual coletada às 6 horas: aspecto panorâmico. Observar a desorganização da estrutura glandular, exibindo ácinos mistos com células mucosas (M) volumosas com borramento do limite externo e pequenas semiluas serosas (seta cheia) e ductos intralobulares em necrose avançada (D) entremeados pelo estroma (seta vermelha). HE

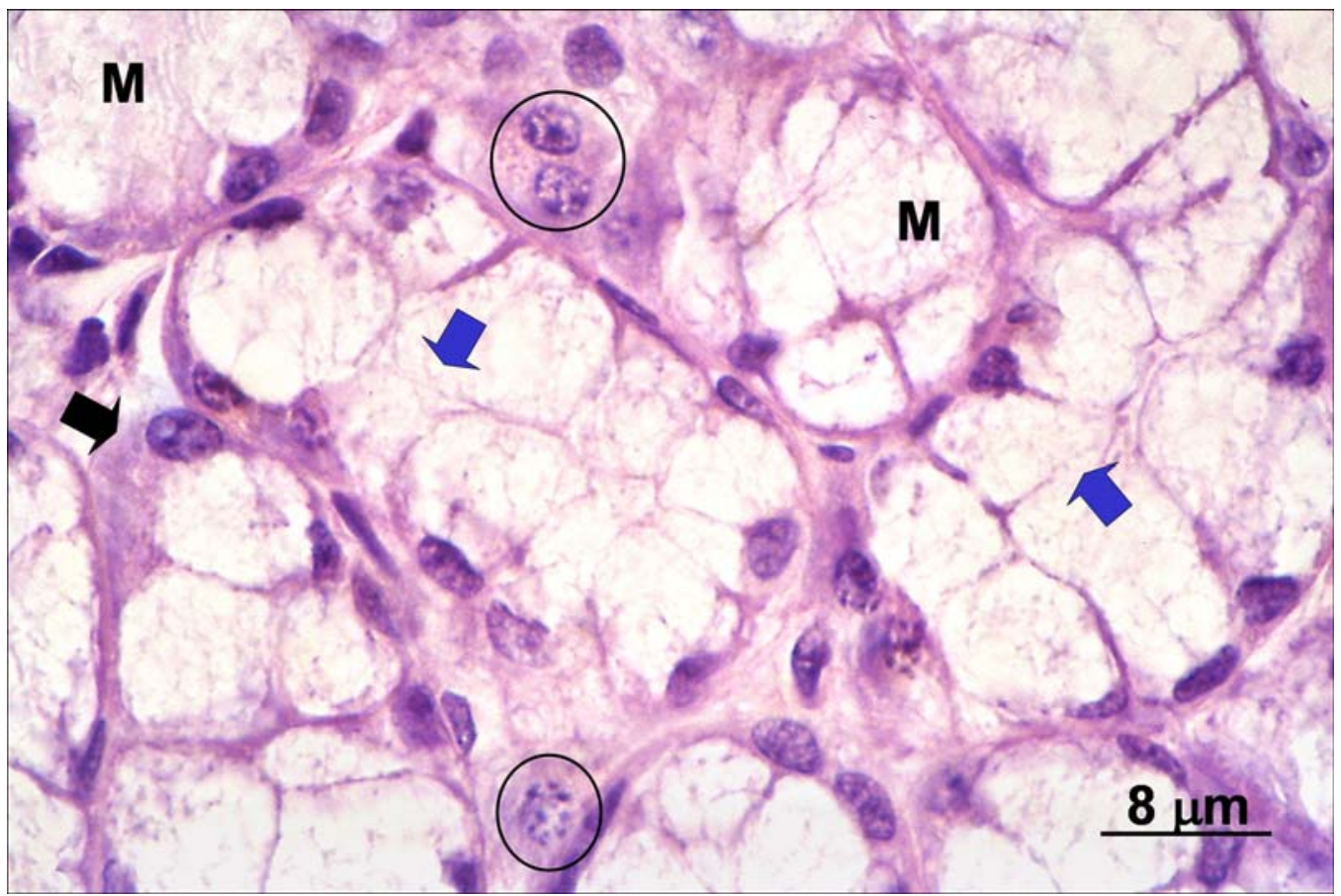

FIGURA 29. Foto micrografia da glândula sublingual coletada às 6 horas: detalhe dos ácinos mistos exibindo algumas células mucosas (M) com perda da integridade do seu limite externo (seta azul) e cariorrexe (círculo) e células serosas (seta cheia). HE 


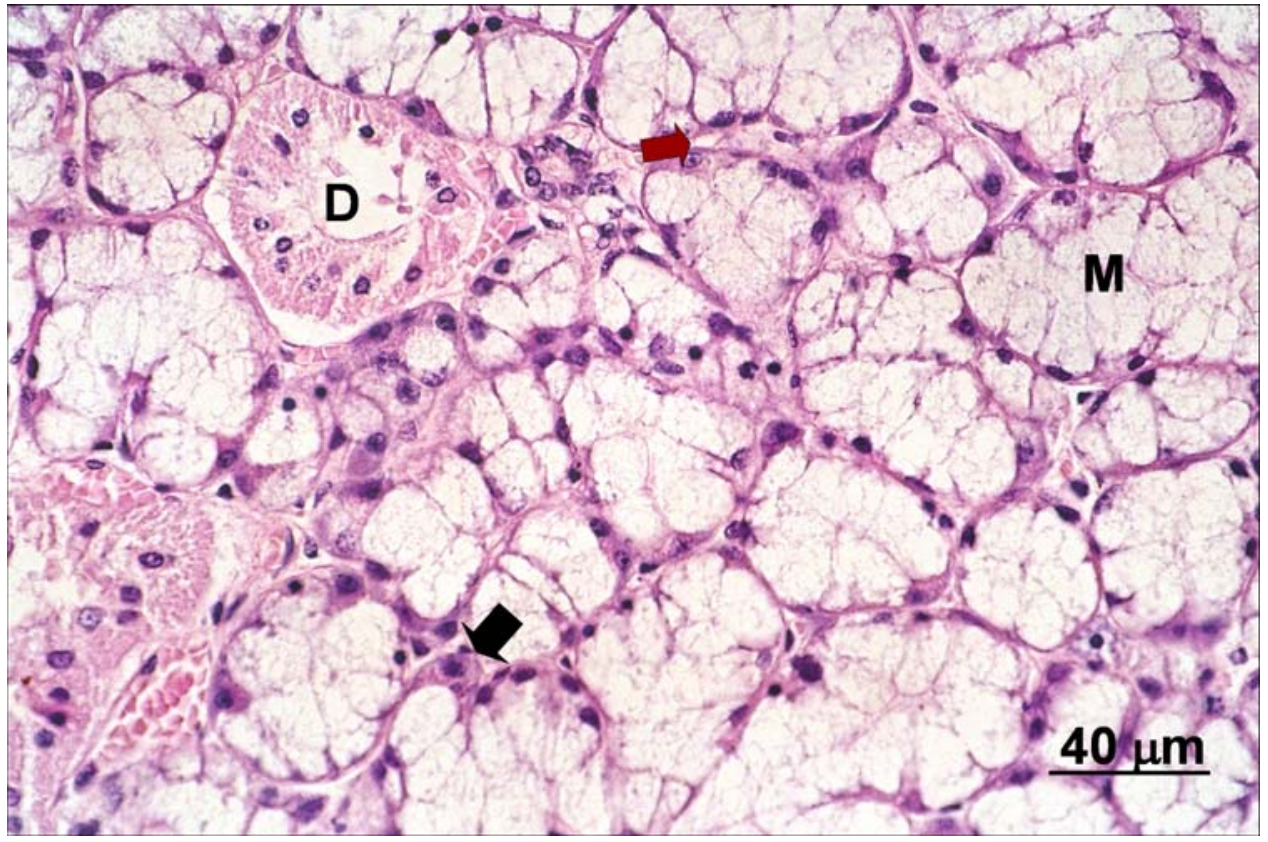

FIGURA 30. Foto micrografia da glândula sublingual coletada às 12 horas: aspecto panorâmico. Observar a desorganização da estrutura glandular, exibindo ácinos mistos com células mucosas (M) volumosas com borramento do seu limite externo e pequenas semiluas serosas (seta cheia) e ductos intralobulares em necrose (D) entremeados pelo estroma (seta vermelha). HE

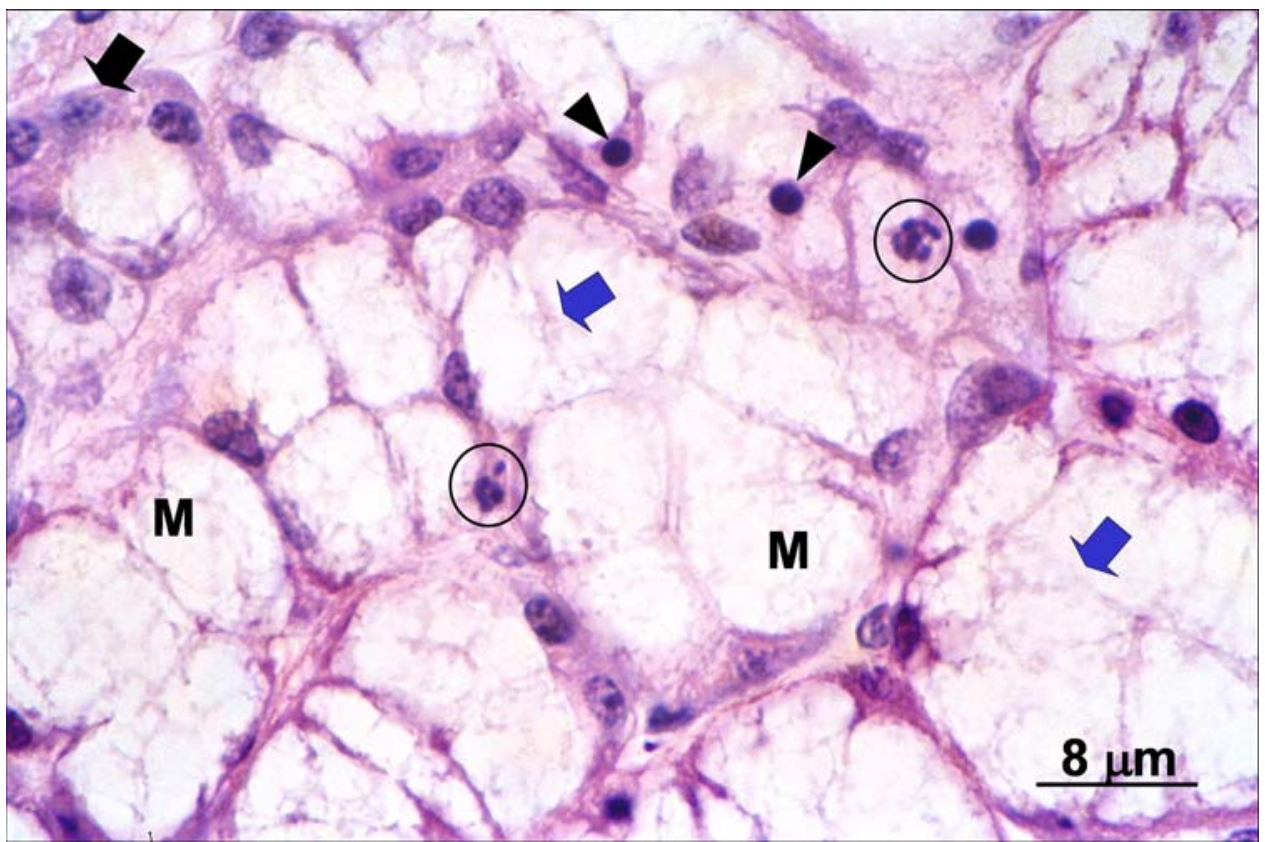

FIGURA 31. Foto micrografia da glândula sublingual coletada às 12 horas: detalhe dos ácinos mistos exibindo células mucosas $(\mathrm{M})$ com perda da integridade do seu limite externo (seta azul) e cariorrexe (círculo) e picnose (cabeça de seta) e células serosas (seta cheia) com cariorrexe. HE 


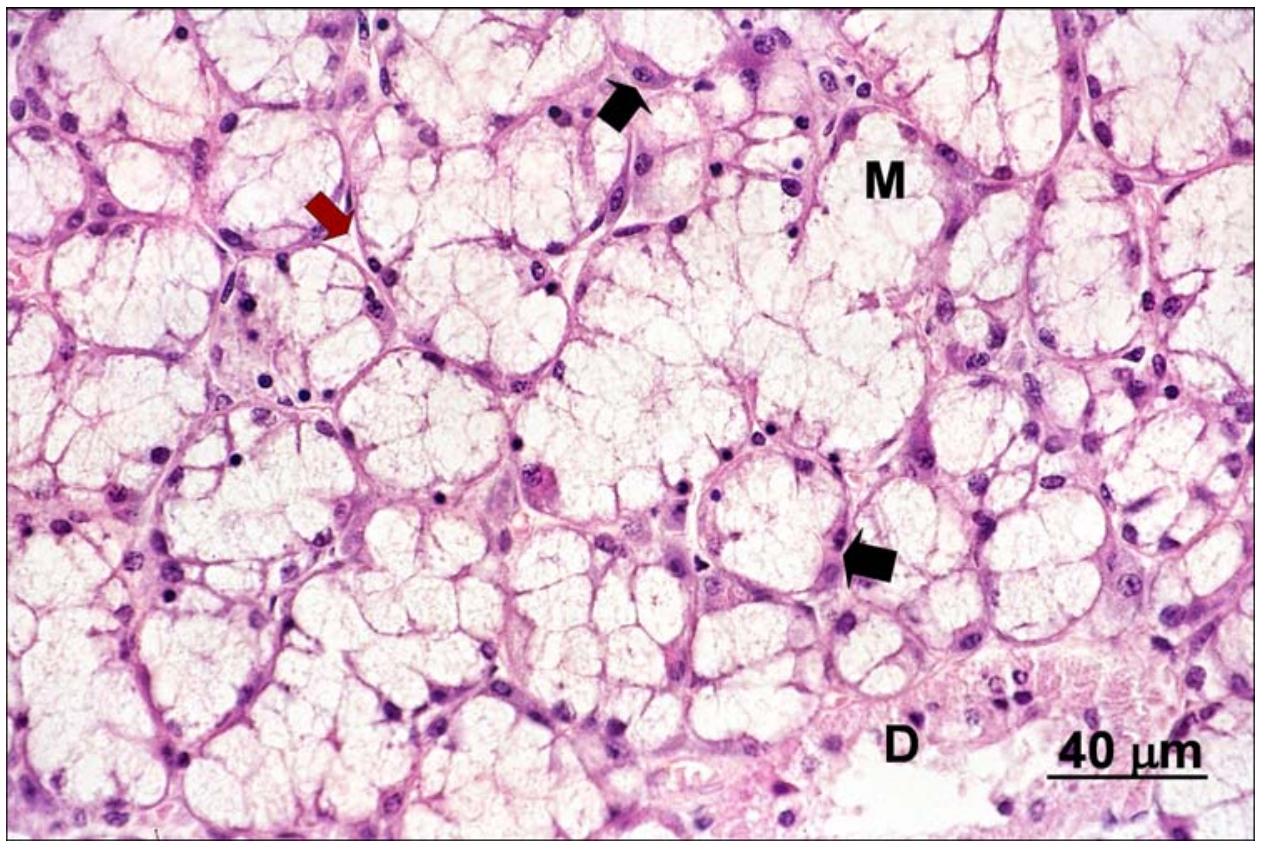

FIGURA 32. Foto micrografia da glândula sublingual coletada às 12 horas: aspecto panorâmico. Observar maior desorganização da estrutura glandular em relação a figura anterior, exibindo ácinos mistos com células mucosas (M) volumosas com borramento do seu limite externo e pequenas semi-luas serosas (seta cheia) e ductos intralobulares em necrose (D) entremeados pelo estroma (seta vermelha). HE

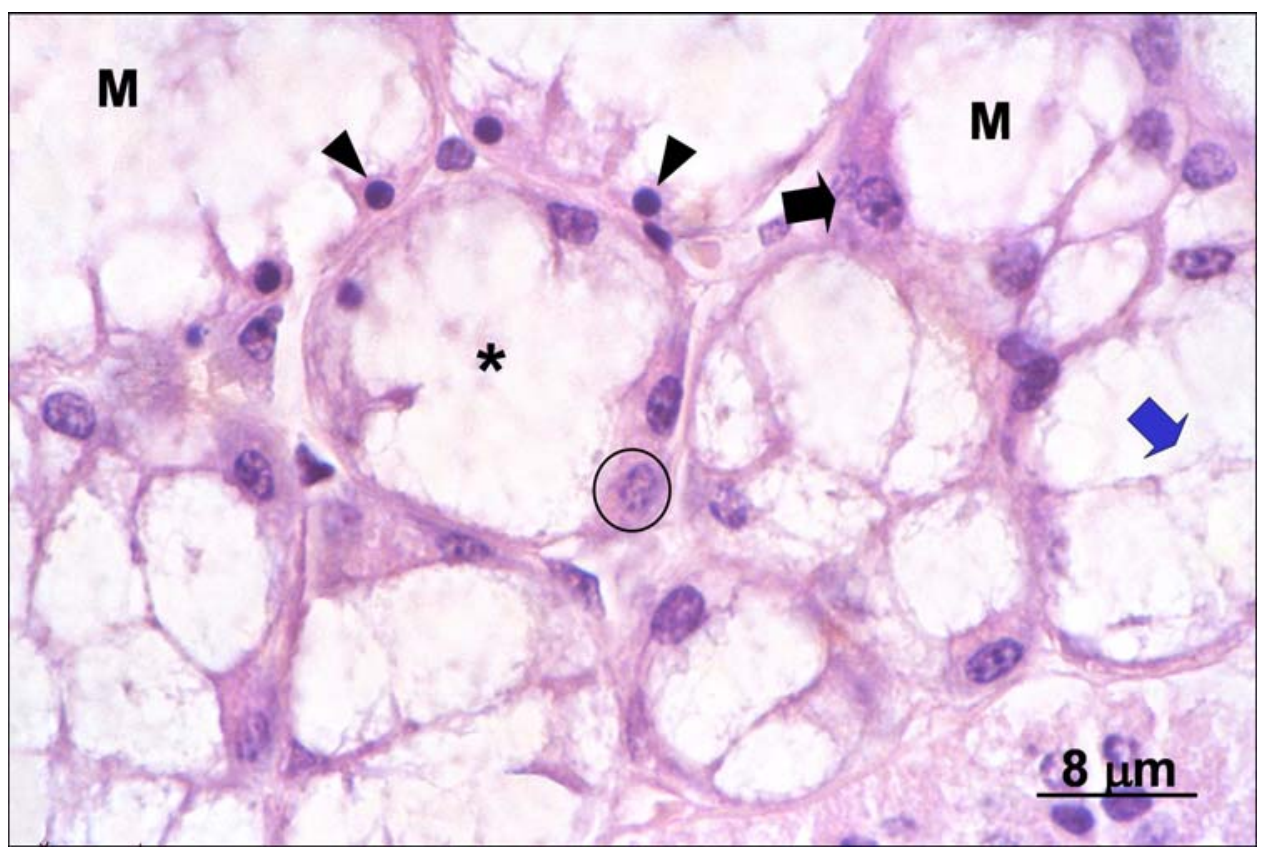

FIGURA 33. Foto micrografia da glândula sublingual coletada às 12 horas: detalhe dos ácinos mistos exibindo células mucosas (M) com perda da sua integridade externa (seta azul) e outros com total desintegração do limite externo (asterisco) e picnose (cabeça de seta) e células serosas (seta cheia) com cariorrexe (círculo). HE 


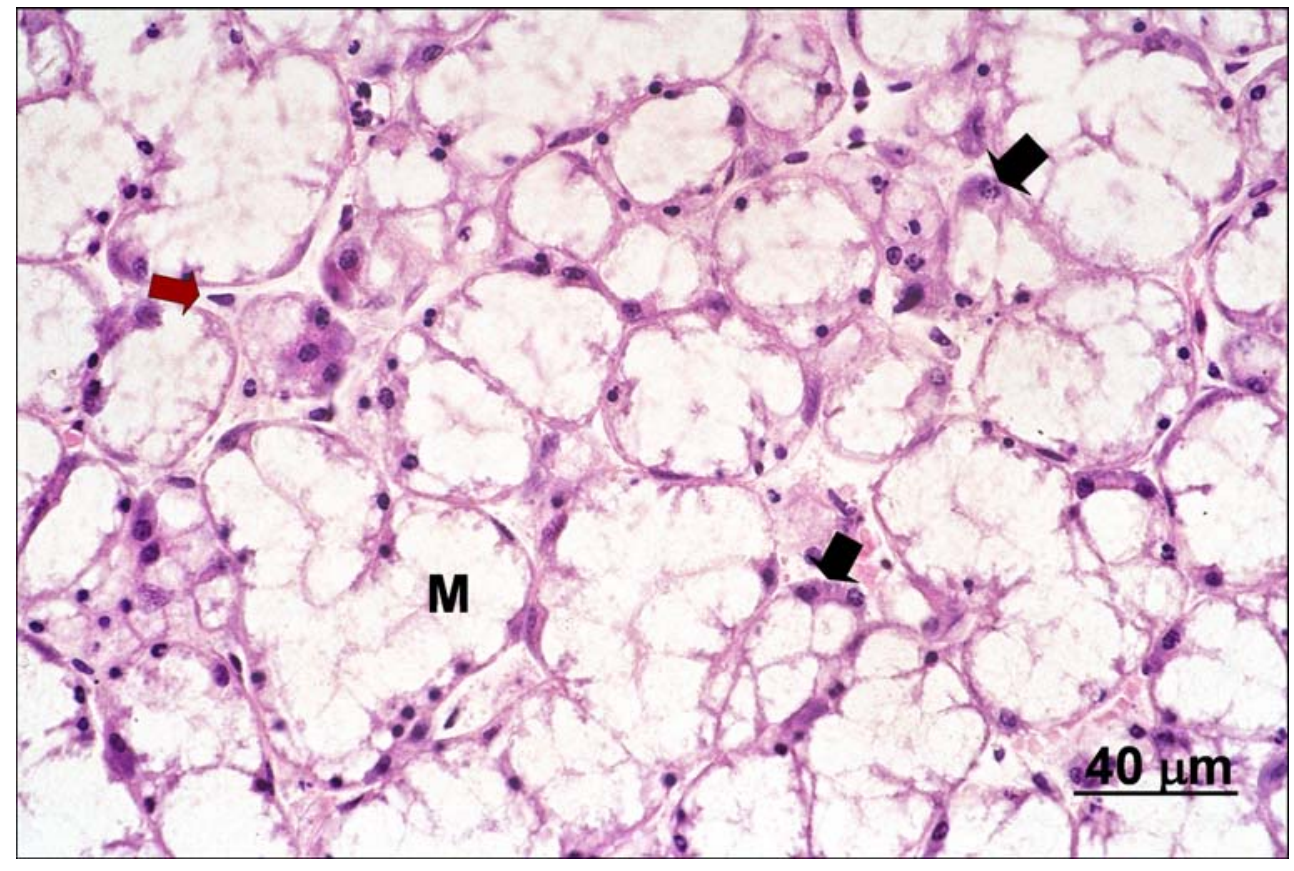

FIGURA 34. Foto micrografia da glândula sublingual coletada às 24 horas: aspecto panorâmico. Observar desorganização da estrutura glandular em relação a figura anterior, exibindo ácinos mistos com células mucosas (M), apresentando borramento do limite externo e pequenas semiluas serosas (seta cheia) entremeados pelo estroma (seta vermelha) pouco visível. Nota-se desaparecimento parcial e total de núcleos em alguns ácinos. HE

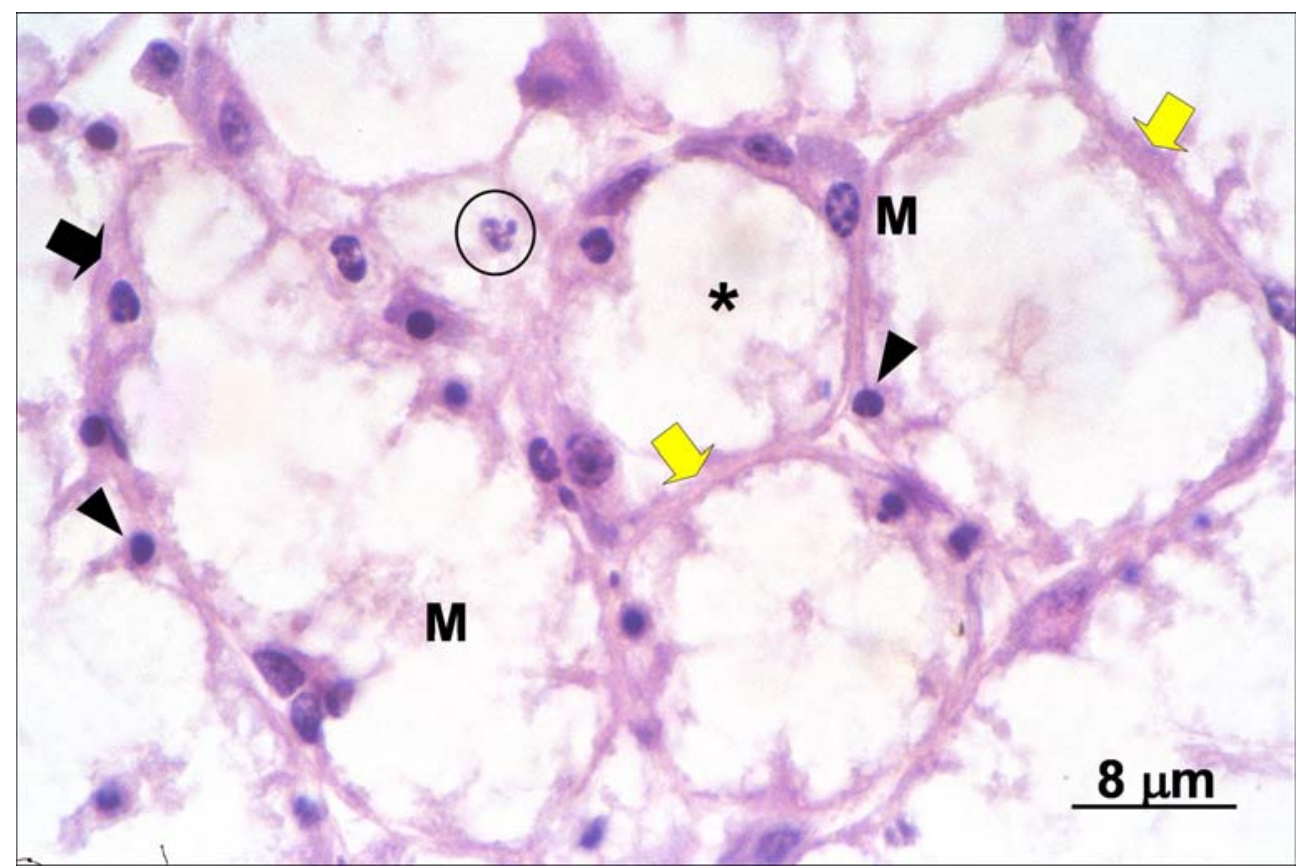

FIGURA 35. Foto micrografia da glândula sublingual coletada às 24 horas: detalhe dos ácinos mistos ainda delimitados (seta amarela), exibindo células mucosas (M) com perda total desintegração do limite externo (asterisco), cariorrexe (círculo) e picnose (cabeça de seta) e células serosas (seta cheia) com núcleo picnótico. Nota-se ácino com um único núcleo remanescente. $\mathrm{HE}$ 


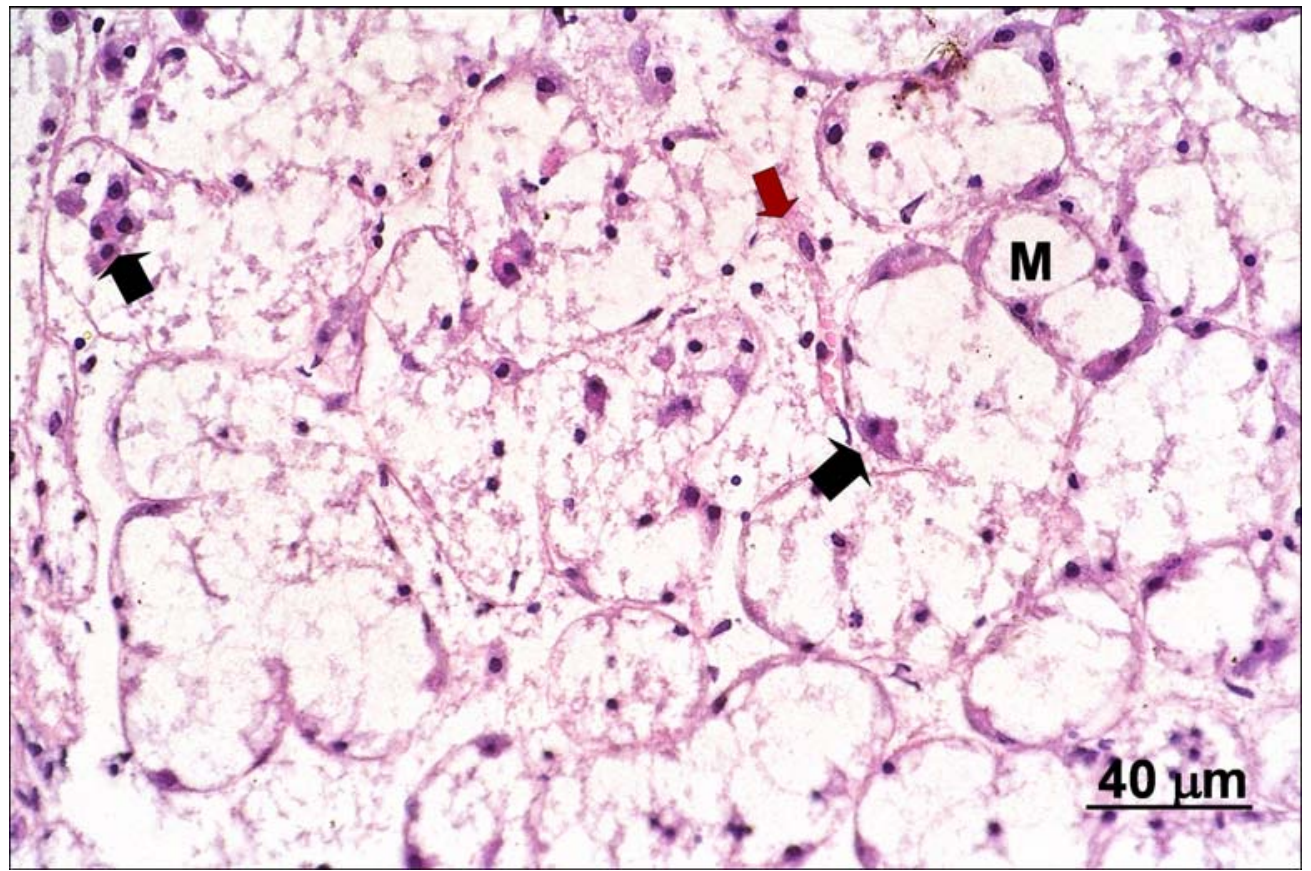

FIGURA 36. Foto micrografia da glândula sublingual coletada às 24 horas: aspecto panorâmico. Observar completa desorganização das estruturas glandulares, exibindo rompimento dos ácinos e extravasamento do conteúdo celular dificultando a visualização do estroma (seta vermelha). HE

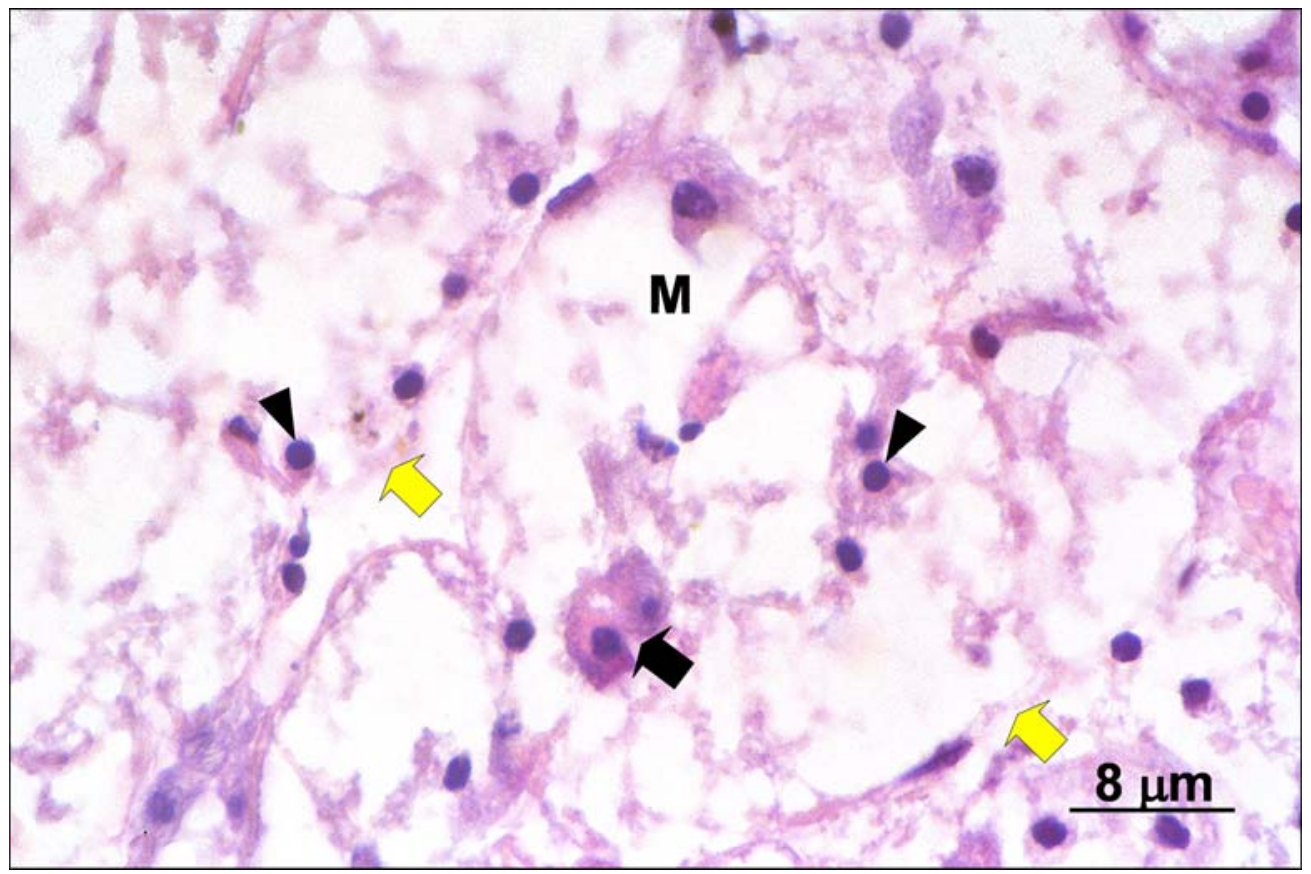

FIGURA 37. Foto micrografia da glândula sublingual coletada às 24 horas: detalhe dos ácinos com rompimento de membrana (seta amarela) e completa desorganização do conteúdo celular e células serosas (seta cheia) íntegras, dispersos no interior da massa amorfa oriunda da destruição das células mucosas. HE 


\section{6 - Discussão}

Esta investigação foi realizada no intuito de suprir uma lacuna quanto aos aspectos microscópicos da autólise post mortem em glândulas salivares. Observamos na literatura inúmeros trabalhos descrevendo e quantificando a autólise post mortem em outros órgãos e tecidos como: coração (HIBBS; BLACK $^{30}$, 1963; ARMIGE et al. ${ }^{31}$, 1976; PENTTILÃ; AHONEN ${ }^{32}$, 1976; SUKURA; SOVERI; LINDBERG ${ }^{36}$, 1990; MUÑOZ et al. ${ }^{39}$, 1999; TOMITA et al. ${ }^{42}$, 2004), pâncreas (NEVALAINEN; ANTTINEN ${ }^{33}$, 1977; SHIMIZU et al. ${ }^{1}$; TOMITA et al. ${ }^{42}$, 2004), osso temporal (NADOL JR; BURGESS ${ }^{34}$, 1985), rim (EL-SHENNAWY; GEE; APARÍCIO ${ }^{35}$, 1985; TOMITA et al. ${ }^{42}$, 2004), corpo carotídeo (PALLOT; SEKER; ABRAMOVICl ${ }^{37}$, 1992), glândulas sudoríparas (CINGOLANI et al. ${ }^{38}$, 1994) e fígado (TOMITA et al. ${ }^{42}$, 2004). Apenas AZEVEDO ${ }^{11}$, 2003, e MOREIRA $^{12}$, 2005; fizeram menção à autólise post mortem em glândulas salivares humanas. Como achado casual, descreveram alguns aspectos morfológicos em microscopia de luz; e HE. Por outro lado, poucos livros de texto trazem informações sobre autólise de uma maneira geral (COTRAN; KUMAR; COLLINS ${ }^{3}$, 1999; GUIMARÃES ${ }^{2}$, 1982). Assim, buscamos nesta pesquisa quantificar o fenômeno morfometricamente em glândula sublingual de rato. Pela inexistência de trabalhos semelhantes procuramos, neste capítulo, nos ater, principalmente, à discussão dos próprios resultados comparando, quando possível, com achados em outros órgãos e tecidos.

\subsection{Da Metodologia}

Os achados de AZEVEDO ${ }^{11}, 2003$, e MOREIRA ${ }^{12}, 2005$ em humanos não puderam ser relacionados com o período post mortem devido a imprecisão dos dados relativos ao tempo decorrido entre a morte e a necropsia. $O$ planejamento do presente estudo em animais dependeu de estudo piloto para que os períodos post mortem fossem corretamente estabelecidos, para permitirem a aferição gradativa do fenômeno, sempre com o propósito de extrapolarmos as 
informações para o ser humano. Dessa forma foram estabelecidos os tempos de 0, 3, 6, 12 e 24 horas post mortem. Os dois grupos de 25 animais (Figura 1) foram empregados no estudo da mesma variável (tempo) por razões da metodologia morfométrica que implica em grande número de glândulas para executar os diferentes ensaios.

\subsubsection{Da casualização dos campos histológicos}

No presente trabalho utilizamos, para as quantificações morfométricas ao microscópio, a casualização dos campos histológicos por amostragem sistemática (WEIBEL ${ }^{43}$, 1969). Na amostragem sistemática, os campos histológicos são escolhidos a intervalos regulares em cada corte histológico, de tal maneira a ter uma amostra representativa de toda área do corte (PARDINI ${ }^{45}$, 1998). Foi necessário primeiramente mapear um corte da glândula e obter o número total de campos nele contidos. Desta forma, foi possível estabelecer 50 campos por glândula. Como trabalhamos com cinco lâminas de cada glândula (direita e esquerda), 10 campos em cada lâmina foram contados, distribuídos por todo corte, com intervalos regulares entre si. Com os critérios acima, já consagrados em trabalhos do nosso grupo (PARDINI ${ }^{45}, 1998$, MOREIRA $^{47}, 2006$ ), asseguramos a veracidade dos resultados obtidos nesta investigação.

\subsubsection{Dos critérios para gradação da autólise}

AZEVEDO $^{11}, 2003$, e MOREIRA ${ }^{12}, 2005$, encontraram "artefatos" em glândulas de cadáveres de todas as idades. Denominaram o artefato de "autólise acinar", pela inexistência de informações literárias sobre o tema. Era um borramento nos limites das células, quase sempre sem perda do contorno do ácino onde apareciam soltos os núcleos das células acinares.

Com base nestas poucas informações consideramos ácinos íntegros os ácinos mistos e mucosos sem nenhuma alteração morfológica. Eram computados como autolisados, os ácinos mistos e mucosos que apresentavam um mínimo sinal de borramento dos limites das células acinares, independente da gradação do fenômeno. 
Entre os artigos específicos de autólise em outros órgãos, o trabalho de SHIMIZU et al. $^{1}, 1990$, pâncreas, foi o único a determinar a extensão da autólise post mortem, graduando a autólise nas seguintes categorias: grau 0 (sem autólise), grau 1 (até 1/3 do corte com autólise), grau 2 (entre 1/3 e 2/3 do corte com autólise) e grau 3 (mais de $2 / 3$ do corte com autólise). A maioria dos trabalhos estudados apenas se referia ao fenômeno, sem graduá-lo (HIBBS; BLACK $^{30}$, 1963; PENTTILÃ; AHONEN ${ }^{32}$, 1976; NEVALAINEN; ANTTINEN ${ }^{33}$, 1977; EL-SHENNAWY; GEE; APARÍCIO ${ }^{35}$, 1985; SUKURA; SOVERI; LINDBERG $^{36}, 1990 ; \quad$ SHIMIZU et al. $^{1}$, 1990; PALLOT; SEKER; ABRAMOVICl ${ }^{37}, 1992$; CINGOLANI et al. ${ }^{38}, 1994$;MUÑOZ et al. ${ }^{39}, 1999$ e TOMITA et al. ${ }^{42}$, 2004). Nós, igualmente a SHIMIZU et al. ${ }^{1}, 1990$, procuramos graduar o fenômeno relacionando a sua gradação ao tempo post mortem, oferecendo dessa maneira, mais detalhes para a compreensão do fenômeno.

\subsection{Dos resultados}

\subsubsection{Dos resultados quantitativos}

PARTE A: Estudo da evolução do processo de autólise nos diferentes períodos post mortem

\subsubsection{Da massa corporal e glandular}

A massa corporal dos ratos estudados não apresentou diferenças estatisticamente significantes entre os grupos $(p=0,145)$, mostrando assim a homogeneidade da amostra quanto o tamanho e idade dos animais (Tabela 1 e Figura 12). Já a massa glandular sublingual aumentou significantemente $26 \%$ $(p<0,01)$ entre 0h e 6h, mantendo-se constante entre 6 e 24h $(p>0,05)$ (Tabela 2 e Figura 13). Tais resultados sugerem que, entre 0 e $6 \mathrm{~h}$, as glândulas possam ter incorporado líquido proveniente do interstício ou dos tecidos circunjacentes de forma geral. A degradação do esqueleto das células aumentaria a concentração interna do órgão absorvendo líquido permeabilizado através da cápsula. 


\subsubsection{Da densidade, fator de retração e volume processado da glândula}

A densidade e o fator de retração da glândula sublingual não apresentaram diferença estatisticamente significante entre os grupos estudados $(p=0,161$ e $p=0,297$, respectivamente) (Tabelas 3 e 4; e Figuras 14 e 15). O volume processado da glândula sublingual aumentou 17,13\% $(p<0,01)$ entre Oh e $12 \mathrm{~h}$ e se manteve constante entre 12 e $24 \mathrm{~h}(\mathrm{p}>0,05)$ (Tabela 5 e Figura 16). edema intracelular pode explicar o aumento de volume, já que é referido como característica inicial do processo de autólise (GUIMARÃES ${ }^{2}, 1982$ ). Posteriormente a hidratação de toda a glândula resultaria do aumento da osmolaridade interna do órgão, o que propiciaria a incorporação de líquidos.

\subsubsection{Da densidade de volume}

Autólise é a digestão catalítica das células ou dos tecidos por enzimas lisossomais após a morte. O fenômeno pode demorar horas para ocorrer. Por exemplo, num caso de morte súbita provocada por infarto agudo do miocárdio, as primeiras evidências histológicas de necrose manifestam-se 4-12 horas mais tarde (COTRAN; KUMAR; COLLINS ${ }^{3}$, 1999). AZEVEDO et al. ${ }^{40}$, não acreditam que o mesmo ocorra em indivíduos que morreram em conseqüência a processos crônicos, tais como: neoplasias malignas, doenças cardiovasculares e respiratórias crônicas, diabete melito, etc. O trabalho de SHIMIZU et al. ${ }^{1}$, em pâncreas, mostra que o grau de autólise pode estar relacionado ao modo do óbito (agudo ou crônico). Segundo os autores, isto se deve à ação de uma enzima, a catepsina, uma proteinase intracelular encontrada em muitos tecidos animais, abundante no fígado, rim e baço, que é inativada pelo formaldeído, quando a peça é fixada. Indivíduos que morrem devido a processos crônicos apresentariam menor quantidade ou atividade dessa enzima do que aqueles que morrem por processos agudos. Assim, a autólise na morte aguda seria severa, e na crônica seria moderada. (SHIMIZU et al. ${ }^{1}$ )

Vários pesquisadores consideram que o intervalo post mortem é o fator que mais influencia a autólise, ou seja, quanto mais longo o tempo de óbito, mais extensa é a autólise post mortem. Porém, há casos relatados de ausência de 
autólise com um tempo de óbito de 40 horas e autólise discreta em intervalo post mortem de 2 horas (SHIMIZU et al. ${ }^{1}$ ). Deste modo, além do tipo de óbito e do intervalo post mortem, outros fatores como, por exemplo, a temperatura do corpo no momento do óbito, a hora do óbito, a temperatura do ambiente, entre outros, podem influenciar a autólise post mortem, daí o cuidado que foi tomado na atual pesquisa, uniformatizando estas diversas variáveis.

No presente estudo, foi observada uma correlação estatisticamente significante entre a autólise e o período post mortem, isto é, a autólise aumenta proporcionalmente com o passar do tempo post mortem, concordando com os achados de SHIMIZU et al. ${ }^{1}$, 1990, NADOL JR; BURGESS ${ }^{34}$, 1985 e MUÑOZ et al. $^{39}$, 1999. Morfometricamente, verificamos que a densidade de volume dos ácinos autolisados da glândula sublingual cresceu significantemente com 0 aumento do período post mortem $(p<0,05)$. Assim, nos períodos de 3, 6, 12 e 24 horas o percentual total dos ácinos autolisados foi, respectivamente, 2,7\%, 47\%, 91\% e 100\% (Tabela 6 e Figura 17).

O maior índice de autólise ocorreu no período entre 3 e 6 horas post mortem, estando quase que completa após 12 horas. Estas observações coincidem com os achados de NEVALAINEN; ANTTINEN ${ }^{33}, 1977$, em células acinares pancreáticas de ratos. Os autores verificaram ainda, que nesse período ocorre uma perda gradual da organização estrutural do órgão até chegar à desintegração celular dos ácinos. Eventos semelhantes foram observados nas glândulas sublinguais (Figuras 26, 27, 28, 29, 30, 31, 32 e 33).

\subsubsection{Do volume absoluto}

O volume absoluto dos ácinos íntegros diminuiu significantemente, entre 3 e $12 \mathrm{~h}$ post mortem, passando de $33 \mathrm{~mm}^{3}$ ás $3 \mathrm{~h}$ para $2,22 \mathrm{~mm}^{3}$ ás $12 \mathrm{~h}$, estando ausente às 24 horas. Nos demais períodos, não houve modificações significantes. Analisando a Tabela 7 e a Figura 18 é possível especular que esta perda, no período de 3 a $12 \mathrm{~h}$ foi linear e que a perda de $31 \mathrm{~mm}^{3}$ no volume absoluto dos ácinos ocorreu a uma velocidade média, relativamente constante, de $3,5 \mathrm{~mm}^{3}$ /hora no período. Por outro lado, o volume absoluto dos ácinos 
autolisados cresceu também linearmente um total de $37 \mathrm{~mm}^{3}$ no mesmo período de 3 a $12 \mathrm{~h}$, a uma velocidade de $4,1 \mathrm{~mm}^{3} /$ hora.

O volume absoluto total aumentou com o passar das horas, apresentando o menor volume no período de 0 hora $\left(33,14 \mathrm{~mm}^{3}\right)$. Esse volume aumentou $32,11 \%$, chegando a $43,78 \mathrm{~mm}^{3}$, no período de 24 horas post mortem (Tabela 7).

Comparando os dados numéricos (Tabela 7) é possível verificar que o ganho de volume absoluto pelos ácinos autolisados é ao redor de 17-20\% maior que a perda observada no volume absoluto dos ácinos íntegros no período de $0 \mathrm{a}$ 24 horas, sugerindo a ocorrência de hidratação intracelular e tecidual durante o processo de autólise. Esta absorção de líquidos pelo tecido em autólise já foi discutida nos itens relativos à massa glandular e volume processado. GUIMARÃES ${ }^{2}, 1982$, foi a única referência a respeito.

PARTE B: Estudo da Interferência do volume de fixador no processo de autólise.

\subsubsection{Da massa corporal e glandular}

A massa corporal dos animais não teve diferença estatisticamente significante $(p=3969)$ mostrando mais uma vez o cuidado na seleção dos animais (Tabela 9 e Figura 19). A massa glandular do grupo de $2 \mathrm{~mL}$ de fixador foi $16,4 \%$ maior em relação as glândulas do grupo de $20 \mathrm{~mL}(p<0,05)$ (Tabela 10 Figura 20). Não encontramos explicação para a diferença encontrada, já que a massa corporal não teve diferença estatísticamente significante e os animais procediam do mesmo lote.

\subsubsection{Da densidade, fator de retração e volume processado da glândula}

A densidade, o fator de retração e o volume processado das glândulas sublinguais não apresentaram diferença estatisticamente significante entre os grupos estudados $(p=0,776 ; p=0,162$ e $p=0,580$ respectivamente) (Tabelas 11, 12 e 13; e Figuras 21, 22 e 23). Vale enfatizar que os cálculos nestes ensaios são 
necessários à obtenção das informações subseqüentes tomando parte em suas fórmulas.

\subsubsection{Da densidade de volume e volume absoluto}

Nas tabelas 14 e 15, observamos que tanto a densidade de volume como o volume absoluto dos ácinos íntegros e autolisados das glândulas sublinguais não se alterou com a variação da quantidade de líquido fixador.

Considerando que, em nosso estudo, a qualidade do fixador era perfeita e a imersão da peça na solução foi imediatamente após a remoção é possível que a diminuição do volume de fixador não tenha repercutido isoladamente de outros fatores referenciados por outros autores como: demora na fixação (ABBEY; SWEENEY ${ }^{24}$, 1972, MARGARONE et al. $^{27}$, 1985), resíduo de formol (WEIR; WEATHERS $^{25}$, 1976, ZEGARELLI ${ }^{26}$, 1978), trauma na peça, transporte e processamento inadequados (MARGARONE et al. ${ }^{27}$, 1985). O volume utilizado apenas para cobrir a peça $(2 \mathrm{~mL})$ pode ter sido suficiente para penetrar todo 0 órgão. Assim, embora os nossos possam ser decorrentes da metodologia empregada, não deixam de acenar que o volume de 10 ou 20 vezes preconizado na literatura (FICARRA; MCCLINTOCK; HANSEN ${ }^{28}$, 1987, OLIVER; SLOAN; PEMBERTON $^{5}$, 2004) pode ser um mito, valendo, como um cuidado a mais, mas não essencial. Vale destacar que o formol é de baixo custo comercial.

\subsubsection{Dos resultados qualitativos}

PARTE A: Estudo da evolução do processo de autólise nos diferentes períodos post mortem

Nos animais do período de 0 hora post mortem, podemos observar que a estrutura glandular se manteve íntegra, mostrando ácinos mucosos, serosos e ductos íntegros (Figuras 24 e 25). No período inicial, 3 horas post mortem, a perda da integridade dos limites das células foi a principal característica observada, mas como o fenômeno ainda estava no início, exigiu cuidados para diferenciar ácino 
com autólise de ácino íntegro (Figuras 26 e 27). Já nos períodos de 6 e 12 horas post mortem, onde $91 \%$ dos ácinos tinham autólise foi possível observar outras características como desaparecimento dos limites das células, presença de granulações no citoplasma e cariorrexe. Os núcleos, também se apresentavam hipercromáticos, picnóticos e começavam migrar para o centro do ácino. 0 contorno acinar se mantinha preservado (Figuras 28, 29, 30, 31, 32 e 33). Nos períodos de 3,6 e 12 horas, células ductais podem ser vistas com sinais de autólise (Figuras 26, 28, 30 e 32). No período de 24 horas post mortem, encontramos uma desorganização total das estruturas glandulares, o que dificultava, às vezes, a delimitação dos ácinos. Eles eram confluentes entre si e com estruturas adjacentes. Os núcleos eram, às vezes, encontrados soltos, no centro dos ácinos (Figuras 34, 35, 36 e 37).

NEVALAINEN; ANTTINEN ${ }^{33}$, 1977, realizaram um estudo ultraestrutural e funcional em ratos das alterações das células acinares pancreáticas durante a autólise. Havia gradual desintegração das membranas das células acinares e edema de vários compartimentos. Concluíram que a desorganização estrutural é gradual e termina em desintegração celular no período de 24 horas post mortem. Guardadas as diferenças da nossa aferição morfológica feita com microscopia de luz, nossos resultados são os mesmos, ou seja, desorganização estrutural e gradual, evoluindo para a desintegração total (Figuras 24, 25, 26, 27 , $28,29,30,31,32,33,34,35,36$ e 37$)$.

Outras semelhanças com nossos achados foram relatadas em glândulas salivares menores colhidas em biópsias bucais (MARGARONE et al. ${ }^{27}$, 1985). Os autores provocaram artefatos cirúrgicos, de transporte e de fixação. Os ácinos foram mais susceptíveis ao artefato de fixação. Eles se tornavam acelulares, restando poucos núcleos, fatos que pudemos observar no ensaio de 24 horas post mortem do nosso material (Figuras 34, 35, 36 e 37). 
PARTE B: Estudo da Interferência do volume de fixador no processo de autólise.

Analisando as Tabelas 14 e 15 percebe-se que alguns poucos ácinos tinham sinais compatíveis com autólise, tão poucos que o coeficiente de erro da aferição para ácinos autolisados foi bem maior que o de ácinos íntegros, retratando, assim, a raridade (Tabela 16). O coeficiente de erro aumenta na medida da raridade da variável estudada. Embora sejam valores desprezíveis merecem discussão já que pelos princípios gerais de biópsia, o diagnóstico microscópico não pode ser prejudicado pela técnica histológica ou por artefatos outros da coleta do material. Assim não cremos que o desaparecimento de limites celulares (setas azuis - Figura 27) encontrado em material fixado com $2 \mathrm{~mL}$ ou $20 \mathrm{~mL}$ tenha sido influenciado pela fixação já que existia nos dois grupos. Não apenas pro tal evidência, mas por experiência de pesquisadores do nosso grupo* tais artefatos existem sempre em dose mínima em material corretamente fixado. Assim não há como não atribuir tais achados a artefatos técnicos de coleta do espécime mesmo que todos os princípios cirúrgicos de biópsia sejam levados em consideração pois, variação de instrumento como punch ou bisturi pode repercutir no resultado (MOULE et al. ${ }^{29}$, 1995). A delicada textura do tecido glandular, certamente, deve influir no aparecimento de artefatos, se compararmos com outros tecidos como um músculo, por exemplo.

\footnotetext{
* Prof. Dr. Rumio Taga, do Departamento de Ciências Biológicas - Área de Histologia da FOB-USP.
} 


\section{7 - Conclusões}

Em função dos resultados obtidos pudemos concluir que:

1. A autólise acinar aumentou significantemente com o aumento do período post mortem $(\mathrm{p}<0,05)$;

2. Houve um aumento da densidade de volume dos ácinos autolisados com o aumento do período post mortem $(\mathrm{p}<0,05)$;

3. Houve um aumento do volume absoluto dos ácinos autolisados entre $3 \mathrm{e}$ $24 \mathrm{~h}(p<0,01)$, enquanto que entre os períodos de 0 e 3 horas não houve diferença estatisticamente significante $(p>0,05)$;

4. Não foram observadas diferenças estatisticamente significantes quando avaliamos a variação do volume de líquido fixador em relação à autólise post mortem. 


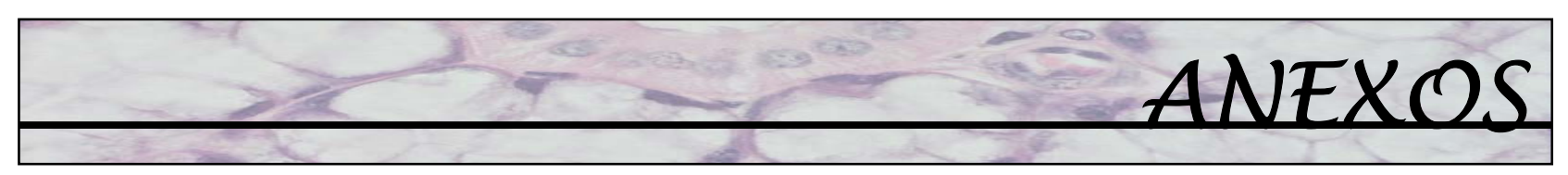




\section{AneXos}

ANEXO 1. Massa corporal (g) dos animais do Grupo I, nos diferentes períodos post mortem

\begin{tabular}{ccccc}
\hline \multicolumn{5}{c}{ Massa corporal (g) } \\
\hline $\mathbf{0 h}$ & $\mathbf{3 h}$ & $\mathbf{6 h}$ & $\mathbf{1 2 h}$ & $\mathbf{2 4 h}$ \\
\hline 361,21 & 367,44 & 289,37 & 337,70 & 324,37 \\
376,69 & 353,68 & 338,36 & 425,15 & 348,62 \\
390,52 & 344,75 & 397,96 & 398,57 & 370,02 \\
370,04 & 392,03 & 338,79 & 378,07 & 358,03 \\
345,23 & 381,41 & 341,06 & 430,89 & 411,56 \\
\hline
\end{tabular}

ANEXO 2. Massa glandular (mg) das sublinguais dos animais do Grupo I, nos diferentes períodos post mortem

\begin{tabular}{ccccc}
\hline \multicolumn{5}{c}{ Massa glandular (mg) } \\
\hline $\mathbf{0 h}$ & $\mathbf{3 h}$ & $\mathbf{6 h}$ & $\mathbf{1 2 h}$ & $\mathbf{2 4 h}$ \\
\hline 79,03 & 84,38 & 97,39 & 93,07 & 96,10 \\
83,18 & 81,16 & 97,68 & 91,41 & 96,25 \\
64,68 & 83,52 & 95,32 & 86,48 & 83,88 \\
70,89 & 73,00 & 82,36 & 92,42 & 113,93 \\
68,36 & 75,86 & 89,19 & 91,51 & 101,68 \\
\hline
\end{tabular}

ANEXO 3. Densidade glandular $\left(\mathrm{mg} / \mathrm{cm}^{3}\right)$ das sublinguais dos animais do Grupo II, nos diferentes períodos post mortem

\begin{tabular}{ccccc}
\hline \multicolumn{5}{c}{ Densidade da glândula ( $\left.\mathbf{m g} / \mathbf{c m}^{\mathbf{3}}\right)$} \\
\hline $\mathbf{0 h}$ & $\mathbf{3 h}$ & $\mathbf{6 h}$ & $\mathbf{1 2 h}$ & $\mathbf{2 4 h}$ \\
\hline 1,056 & 1,041 & 1,042 & 1,047 & 1,052 \\
1,027 & 1,046 & 1,041 & 1,046 & 1,046 \\
1,050 & 1,045 & 1,051 & 1,046 & 1,048 \\
1,056 & 1,043 & 1,043 & 1,046 & 1,067 \\
1,034 & 1,038 & 1,044 & 1,047 & 1,045 \\
\hline
\end{tabular}


ANEXO 4. Fator de retração das glândulas sublinguais dos animais do Grupo II, nos diferentes períodos post mortem

\begin{tabular}{ccccc}
\hline \multicolumn{5}{c}{ Fator de retração } \\
\hline $\mathbf{0 h}$ & $\mathbf{3 h}$ & $\mathbf{6 h}$ & $\mathbf{1 2 h}$ & $\mathbf{2 4 h}$ \\
\hline 0,565 & 0,539 & 0,550 & 0,601 & 0,668 \\
0,786 & 0,600 & 0,547 & 0,576 & 0,541 \\
0,721 & 0,725 & 0,631 & 0,671 & 0,704 \\
0,628 & 0,607 & 0,544 & 0,625 & 0,625 \\
0,666 & 0,583 & 0,636 & 0,706 & 0,572 \\
\hline
\end{tabular}

ANEXO 5. Volume processado $\left(\mathrm{mm}^{3}\right)$ das glândulas sublinguais dos animais do Grupo II, nos diferentes períodos post mortem

\begin{tabular}{ccccc}
\hline \multicolumn{5}{c}{ Volume Processado $\left.\mathbf{( m m}^{\mathbf{3}}\right)$} \\
\hline $\mathbf{0 h}$ & $\mathbf{3 h}$ & $\mathbf{6 h}$ & $\mathbf{1 2 h}$ & $\mathbf{2 4 h}$ \\
\hline 50,939 & 49,435 & 54,259 & 56,555 & 56,827 \\
53,614 & 47,548 & 54,421 & 55,547 & 56,915 \\
41,690 & 48,931 & 53,106 & 52,551 & 49,601 \\
45,692 & 42,768 & 45,885 & 56,160 & 67,370 \\
44,062 & 44,443 & 49,690 & 55,607 & 60,126 \\
\hline
\end{tabular}


ANEXO 6. Densidade de volume das diferentes estruturas da glândula sublingual dos animais do Grupo I.

\begin{tabular}{|c|c|c|c|}
\hline \multirow{2}{*}{ SUBGRUPOS } & \multicolumn{3}{|c|}{ DENSIDADE DE VOLUME (\%) } \\
\hline & ÁCINOS ÍNTEGROS (\%) & ÁcINOS AUTOLISADOS (\%) & OUTROS (\%) \\
\hline 0H_1 & 65,16 & 0,44 & 34,40 \\
\hline $0 \mathrm{H} \_2$ & 72,08 & - & 27,92 \\
\hline 0H_3 & 72,64 & 0,72 & 26,64 \\
\hline OH_4 & 68,98 & - & 31,02 \\
\hline $0 \mathrm{H} \_5$ & 71,16 & 0,42 & 28,42 \\
\hline 3H_1 & 69,32 & 1,48 & 29,20 \\
\hline $3 \mathrm{H} \_2$ & 70,40 & 0,68 & 28,92 \\
\hline 3H_3 & 76,42 & 1,00 & 22,58 \\
\hline 3H_4 & 74,08 & 3,74 & 22,18 \\
\hline $3 H \_5$ & 69,89 & 3,33 & 26,78 \\
\hline $6 H \_1$ & 42,82 & 26,80 & 30,38 \\
\hline $6 \mathrm{H} \_2$ & 54,46 & 15,48 & 30,06 \\
\hline $6 \mathrm{H} \_3$ & 33,84 & 42,34 & 23,82 \\
\hline $6 H_{-} 4$ & 35,12 & 38,72 & 26,16 \\
\hline $6 \mathrm{H} \_5$ & 16,60 & 53,32 & 30,08 \\
\hline 12H_1 & 7,24 & 67,50 & 25,26 \\
\hline 12H_2 & 2,04 & 65,40 & 32,56 \\
\hline 12H_3 & 5,33 & 63,41 & 31,26 \\
\hline 12H_4 & 0,84 & 75,46 & 23,70 \\
\hline
\end{tabular}




$\begin{array}{lccc}\text { 12H_5 } & 4,70 & 70,80 & 24,50 \\ & - & 75,84 & 24,16 \\ \text { 24H_1 } & - & 68,46 & 31,54 \\ \text { 24H_2 } & - & 75,40 & 24,60 \\ \text { 24H_3 } & - & 77,48 & 22,52 \\ \text { 24H_4 } & - & 78,60 & 21,40 \\ \text { 24H_5 } & & & \end{array}$


ANEXO 7. Volume absoluto das diferentes estruturas da glândula sublingual dos animais do Grupo I.

\begin{tabular}{|c|c|c|c|}
\hline \multirow{2}{*}{ SUBGRUPOS } & \multicolumn{3}{|c|}{ VoLUME ABSOLUTO (\%) } \\
\hline & ÁCINOS ÍNTEGROS & ÁcINOS AUTOLISADOS & OUTROS \\
\hline 0H_1 & 33,192 & 0,224 & 17,523 \\
\hline OH_2 & 38,645 & - & 14,969 \\
\hline OH_3 & 30,284 & 0,300 & 11,106 \\
\hline OH_4 & 31,518 & - & 14,174 \\
\hline $0 \mathrm{H} \_5$ & 31,355 & 0,185 & 12,522 \\
\hline $3 \mathrm{H} \_1$ & 34,268 & 0,732 & 14,435 \\
\hline $3 \mathrm{H} \_2$ & 33,474 & 0,323 & 13,751 \\
\hline 3H_3 & 37,393 & 0,489 & 11,049 \\
\hline $3 H_{-} 4$ & 31,683 & 1,600 & 9,486 \\
\hline $3 \mathrm{H} \_5$ & 31,061 & 1,480 & 11,902 \\
\hline $6 H_{-} 1$ & 23,234 & 14,541 & 16,484 \\
\hline $6 \mathrm{H} \_2$ & 29,638 & 8,424 & 16,359 \\
\hline $6 H_{-} 3$ & 17,971 & 22,485 & 12,650 \\
\hline $6 H_{-} 4$ & 16,115 & 17,767 & 12,004 \\
\hline $6 H_{-} 5$ & 8,249 & 26,495 & 14,947 \\
\hline 12H_1 & 4,095 & 38,175 & 14,286 \\
\hline $12 \mathrm{H} \_2$ & 1,133 & 36,328 & 18,086 \\
\hline 12H_3 & 2,801 & 33,323 & 16,427 \\
\hline $12 \mathrm{H} \_4$ & 0,472 & 42,378 & 13,310 \\
\hline
\end{tabular}


12H_5

$$
2,614
$$

39,370

13,624

24H_1

24H_2

24H_3

24H_4

24H_5
43,098

38,964

37,399

52,198

47,259
13,729

17,951

12,202

15,172

12,867 
ANEXO 8. Coeficiente de variação ("erro") das estimativas da densidade de volume dos ácinos íntegros e autolisados da glândula sublingual dos animais do Grupo I.

\begin{tabular}{|c|c|c|}
\hline \multirow{2}{*}{ SUBGRUPOS } & \multicolumn{2}{|c|}{ COEFICIÊNTE DE VARIAÇÃO - “ERRO” (\%) } \\
\hline & ÁCINO ÍNTEGRO & ÁCINO AUTOLISADO \\
\hline 0H_1 & 1,02 & 21,06 \\
\hline OH_2 & 0,87 & - \\
\hline 0H_3 & 0,86 & 16,44 \\
\hline OH_4 & 0,94 & - \\
\hline $0 \mathrm{H} \_5$ & 0,89 & 21,56 \\
\hline 3H_1 & 0,93 & 11,42 \\
\hline $3 \mathrm{H} \_2$ & 0,91 & 16,92 \\
\hline 3H_3 & 0,78 & 13,93 \\
\hline 3H_4 & 0,83 & 7,10 \\
\hline $3 H \_5$ & 0,92 & 7,54 \\
\hline 6H_1 & 1,62 & 2,31 \\
\hline $6 \mathrm{H} \_2$ & 1,28 & 3,27 \\
\hline $6 \mathrm{H} \_3$ & 1,96 & 1,63 \\
\hline $6 H \_4$ & 1,90 & 1,76 \\
\hline $6 \mathrm{H} \_5$ & 3,14 & 0,97 \\
\hline 12H_1 & 5,01 & 1,02 \\
\hline 12H_2 & 9,70 & 1,06 \\
\hline 12H_3 & 5,90 & 0,80 \\
\hline 12H_4 & 15,21 & 0,90 \\
\hline
\end{tabular}


12H_5

6,31

0,79 


\begin{tabular}{ccc} 
24H_1 & - & 0,95 \\
24H_2 & - & 0,80 \\
24H_3 & - & 0,75 \\
24H_4 & - & 0,73 \\
24H_5 & - & - \\
\hline
\end{tabular}

ANEXO 9. Massa corporal (g) dos animais dos grupos onde houve variação de volume do líquido fixador

\begin{tabular}{cc}
\hline \multicolumn{2}{c}{ Massa corporal (g) } \\
\hline Grupo 2mL & Grupo 20mL \\
\hline 370,40 & 361,21 \\
398,34 & 376,69 \\
338,48 & 390,52 \\
397,60 & 370,04 \\
403,25 & 345,23 \\
\hline
\end{tabular}

ANEXO 10. Massa glandular (mg) da sublingual dos animais dos grupos onde houve variação de volume do líquido fixador

\begin{tabular}{cc}
\hline \multicolumn{2}{c}{ Massa glandular (mg) } \\
\hline Grupo 2mL & Grupo 20mL \\
\hline 87,35 & 79,03 \\
91,64 & 83,18 \\
80,12 & 64,68 \\
81,75 & 70,89 \\
85,40 & 68,36 \\
\hline
\end{tabular}


ANEXO 11. Densidade glandular $\left(\mathrm{mg} / \mathrm{cm}^{3}\right)$ das sublinguais dos animais dos grupos onde houve variação de volume do líquido fixador

\begin{tabular}{cc}
\hline \multicolumn{2}{c}{ Densidade da glândula $\left(\mathbf{m g} / \mathrm{cm}^{3}\right)$} \\
\hline Grupo 2mL & Grupo $20 \mathrm{~mL}$ \\
\hline 1,032 & 1,056 \\
1,046 & 1,027 \\
1,057 & 1,050 \\
1,049 & 1,056 \\
1,048 & 1,034
\end{tabular}

ANEXO 12. Fator de retração das glândulas sublinguais dos animais dos grupos onde houve variação de volume do líquido fixador

\begin{tabular}{cc}
\hline \multicolumn{2}{c}{ Fator de retração } \\
\hline Grupo 2mL & Grupo 20mL \\
\hline 0,599 & 0,565 \\
0,596 & 0,786 \\
0,528 & 0,721 \\
0,552 & 0,628 \\
0,711 & 0,666
\end{tabular}

ANEXO 13. Volume processado $\left(\mathrm{mm}^{3}\right)$ das glândulas sublinguais dos animais dos grupos onde houve variação de volume do líquido fixador

\begin{tabular}{cc}
\hline \multicolumn{2}{c}{ Volume processado $\left(\mathrm{mm}^{3}\right)$} \\
\hline Grupo 2mL & Grupo 20mL \\
\hline 49,838 & 0,565 \\
52,286 & 0,786 \\
45,713 & 0,721 \\
46,643 & 0,628 \\
48,725 & 0,666 \\
\hline
\end{tabular}


ANEXO 14. Densidade de volume das diferentes estruturas da glândula sublingual. do grupo utilizado para avaliar a variação de volume de formol.

\begin{tabular}{|c|c|c|c|}
\hline \multirow{2}{*}{ GRUPOS } & \multicolumn{3}{|c|}{ DENSIDADE DE VoLUME (\%) } \\
\hline & ÁCINOS ÍNTEGROS & ÁCINOS AUTOLISADOS & OUTROS \\
\hline 2ML_1 & 75,72 & - & 24,28 \\
\hline $2 \mathrm{ML} \_2$ & 74,84 & 0,36 & 24,80 \\
\hline 2ML_3 & 74,98 & - & 25,02 \\
\hline $2 M L \_4$ & 77,34 & - & 22,66 \\
\hline 2ML_5 & 71,28 & 2,79 & 25,93 \\
\hline 20ML_1 & 65,16 & 0,44 & 34,40 \\
\hline 20ML_2 & 72,08 & - & 27,92 \\
\hline 20ML_3 & 72,64 & 0,72 & 26,64 \\
\hline $20 \mathrm{ML} \_4$ & 68,98 & - & 31,02 \\
\hline $20 \mathrm{ML} \_5$ & 71,16 & 0,42 & 28,42 \\
\hline
\end{tabular}


ANEXO 15. Volume absoluto de ácinos íntegros e autolisados dos animais dos grupos estudados que variam na quantidade de líquido fixador

\begin{tabular}{|c|c|c|c|}
\hline \multirow{2}{*}{ SUBGRUPOS } & \multicolumn{3}{|c|}{ VoLUME ABSOLUTO (\%) } \\
\hline & ÁCINOS ÍNTEGROS & ÁCINOS AUTOLISADOS & OUTROS \\
\hline $2 \mathrm{ML}$ & 37,737 & - & 12,101 \\
\hline $2 \mathrm{ML}$ & 39,131 & 0,188 & 12,967 \\
\hline $2 \mathrm{ML}$ & 34,276 & - & 11,437 \\
\hline $2 \mathrm{ML}$ & 36,074 & - & 10,569 \\
\hline $2 \mathrm{ML}$ & 34,731 & 1,359 & 12,634 \\
\hline $20 \mathrm{ML}$ & 33,192 & 0,224 & 17,523 \\
\hline $20 \mathrm{ML}$ & 38,645 & - & 14,969 \\
\hline $20 \mathrm{ML}$ & 30,284 & 0,300 & 11,106 \\
\hline $20 \mathrm{ML}$ & 31,518 & - & 14,174 \\
\hline $20 \mathrm{ML}$ & 31,355 & 0,185 & 12,522 \\
\hline
\end{tabular}


ANEXO 16. Coeficiente de variação ("erro") das estimativas da densidade de volume dos ácinos íntegros e autolisados da glândula sublingual dos animais do grupo utilizado para avaliar a variação de volume de formol.

\begin{tabular}{ccc}
\hline SUBGRUPOS & \multicolumn{2}{c}{ COEFICIÊNTE DE VARIAÇÃO - “ERRO”(\%) } \\
& ÁCINO ÍNTEGRO & ÁcINO AUTOLISADO \\
\hline OH_1 & 0,79 & - \\
OH_2 & 0,81 & 23,30 \\
0H_3 & 0,81 & - \\
0H_4 & 0,76 & - \\
0H_5 & 0,89 & 8,27 \\
3H_1 & 1,02 & 21,06 \\
3H_2 & 0,87 & - \\
3H_3 & 0,86 & 16,44 \\
3H_4 & 0,94 & - \\
3H_5 & 0,89 & 21,56 \\
\hline
\end{tabular}

- = ausente 


\section{Referências Bibliográficas}

1. Shimizu M, Hayashi T, Saitoh Y, Ohta K, Itoh H. Postmortem autolysis in the pancreas: multivariate statistical study. The influence of clinicalpathological conditions. Pancreas. 1990, 5(1):91-4.

2. Guimarães SAC. Reações celulares às agressões. In: Guimarães SAC. Patologia Básica da cavidade bucal. Rio de Janeiro (RJ): Guanabara Koogan; 1982. p.40-60.

3. Kumar V, Abbas AK, Fausto N. Robbins e Cotran Patologia - Bases patológicas das doenças. $7^{\mathrm{a}}$ ed. Rio de Janeiro (RJ): Elsevier; 2005. p. 22.

4. Genovese WJ. Metodologia do exame clínico em odontologia. $2^{a}$ ed., São Paulo: Pancast, 1992. 391p.

5. Oliver RJ, SLOAN P, Pemberton MN. Oral biopsies: methods and applications. Br Dent J. 2004 mar, 196(6):329-33.

6. Abuláfia J. Histologia e histopatologia da mucosa e semi - mucosa bucal. Biópsia. In: Grinspan D. Enfermedades de la boca. Bueno Aires: Mundi; 1970. p. 417-20.

7. Fleury RN. Biópsia |Resumos de aulas teóricas - Faculdade de Odontologia de Bauru - USP| 1978.

8. Michalany J. Cirurgião, técnica histológica e patologia clínica. Ver Ass Med Brasil. 1979 jan, 25(1):44-6.

9. Neves JFD. Martins MH, Grein RL. Citologia esfoliativa e biópsia. Odontólogo moderno. 1981, 8(6):17-21.

10. Tommasi AF. Exames Complemetares. In: Tommasi AF. Diagnóstico em patologia bucal. $3^{\mathrm{a}}$ ed. São Paulo (SP): Pancast; 2002. p.43-7.

11. Azevedo LR. Alterações microscópicas com a idade em glândulas sublinguais humanas. Estudo postmortem (Tese - Doutorado). Bauru: Faculdade de Odontologia de Bauru, Universidade de São Paulo, 2003. 
12. Moreira CR. Alterações histológicas da glândula sublingual humana com a idade. Estudo morfométrico. (Dissertação - Mestrado). Bauru: Faculdade de Odontologia de Bauru, Universidade de São Paulo, 2005.

13. Leeson CR, Both WG. Histological, histochemical and electromicroscopic observations on the post-natal development of the major sublingual gland of the rat. J Dent Res. 1961, 40(4):838-45.

14. Taga R. Evolução das populações celulares das glândulas parótida e sublingual do rato durante a vida pós-natal inicial avaliada por estudos morfométricos, bioquímicos, radioautográficos e ultraestruturais. (Tese Doutorado). Bauru: Faculdade de Odontologia de Bauru, Universidade de São Paulo, 1976.

15. Hassunuma R, Taga R. Allometric study of the postnatal development of the rat sublingual glands. Okajimas Folia Anat Jpn. 1996, 73(5):265-71.

16. Taga $R$, Sesso A. Postnatal development of the rat sublingual glands. $A$ morphometric and radioautographic study. Arch Histol Cytol. 1998, 61(5):41726.

17. Taga $R$, Sesso A. Ultrastructure of the rat sublingual gland during period of high proliferative activity in postnatal development. Braz J Morphol Sci. 2002, 19(2):55-62.

18. Madi KF, Cestari TM, Taga R. Growth rate of the cell populations of the rat sublingual gland during the early postnatal period. Cienc Odontol Bras. 2003, 6(1):18-23.

19. Leeson CR. Structure of salivary glands. In: Handbook of Physiology. Washington: American Physiological Society. 1967, 2: 463-95.

20. Pinkstaff AC. The cytology of salivary glands. Int Rev Cytol. 1979, 63:141-61.

21. Culp DJ, Graham LA, Latchney LR. Rat sublingual gland as a model to study glandular mucous cell secretion. Am J Physiol. 1991 jun, 260(6):C1233-44.

22. Hernandes R, Bassi WE, Stipp ACM, Taga R. Estudo estereológico dos ácinos de glândulas sublinguais de ratos jovens e adultos. Ver Ciênc Biomed. 1995, 15:31-9. 
23. Lima MC, Sottovia-Filho D, Cestari TM, Taga R. Morphometric characterization of sexual differences in the rat sublingual gland. Braz Oral Res. 2004, 18(1):53-8.

24. Abbey LM, Sweeney T. Fixation artefacts in oral biopsy specimes. Va Dent J. 1972 dec; 49(6):31-4.

25. Weir JC, Weathers DR. A fixation artifact simulating acantholytic disease. Oral Surg. 1976 jan, 41(1):105-8.

26. Zegarelli DJ. Common problems in biopsy procedure. J Oral Surg. 1978 aug, 36(8):644-7.

27. Margarone JE, Natiella JR, Vaughan, CD. Artifacts in oral biopsy specimens. J Oral Maxilofac Surg. 1985, 43:163-72.

28. Ficarra G, McClintock B, Hansen LS. Artefacts created during oral biopsy procedures. J Craniomasillofac Surg. 1987 feb, 15(1):34-7.

29. Moule I, Parsons PA, Irvine GH. Avoiding artifacts in oral biopsies: the punch biopsy versus the incisional biopsy. $\mathrm{Br} \mathrm{J}$ Oral Maxillofac Surg. 1995, 33(4):244-7.

30. Hibbs RG, Black WC. Electron Microscopy of post-mortem changes in the rat myocardium. Anat Rec. 1963 oct, 147:261-72.

31. Armiger LC, Seelye RN, Carnell VM, Smith CU, Gavin JB, Herdson MB. Morphologic and biochemical changes in autolysing dog heart muscle. Lab Invest. 1976 apr; 34(4):357-62.

32. Penttilä A, Ahonen A. Electron microscopical and enzyme histochemical changes in the rat myocardium during prolonged autolysis. Beitr Pathol Bd. 1976, 157:126-41.

33. Nevalainen TJ, Anttinen J. Ultrastructural and funcional changes in pancreatic acinar cells during autolysis. Virchows Archiv B. 1997 mar, 24:197-207.

34. Nadol JB, Burgess B. A study of postmortem autolysis in the human organ of corti. J Comp Neurol. 1985 jul, 237(3):333-42.

35. El-Shennawy E, Gee DJ, Aparício SR. Renal tubular epithelia ultrastructure in autolysis. J Pathol. 1985 sep, 147(1):13-21. 
36. Sukura A, Soveri T, Lindberg LA. Morphometric quantitation of early autolytic changes in rat myocardial cells. Res Vet Sci. 1990 may, 48(3):276-9.

37. Pallot DJ, Seker M, Abramovici A. Post-mortem changes in the normal rat carotid body: possible implications for human histopathology. Virchows Arch A Pathol Anat Histopathol. 1992, 420(1):31-5.

38. Cingolani M, Osculati A, Tombolini A, Tagliabracci A, Ghimenton C, Ferrara $\mathrm{SD}$. Morphology of sweat glands in determining time of death. Int $\mathrm{J}$ Leg Med. 1994 mar,107(3):132-40.

39. Muñoz DR, Almeida M, Lopes EA, Iwamura ESM. Potential definition of the time of death from autolytic myocardial cells: a morphometric study. For Sci Int. 1999 oct, 104(2-3):81-9.

40. Azevedo LR, Damante JH, Lara VS. Alterações microscópicas com a idade em glândulas sublinguais humanas. Achados causais em um estudo postmortem. Braz Oral Res. v.18, Supplement, 2004. Resumo. Trabalho apresentado no $21^{\circ}$ Encontro Anual da SBPqO, set. 2004

41. Azevedo LR, Damante JH, LaraVS, Lauris JR. Age - related changes in human sublingual glands: a post mortem study. Arch Oral Biol. 2005 jun, 50(6):565-74.

42. Tomita Y, Nihira M, Ohno Y, Sato S. Ultrastructural changes during in situ early postmortem autolysis in kidney, pancreas, liver, heart and skeletal muscle of rats. Legal Medecine. 2004, 6:25-31.

43. Weibel ER. Stereological principles for morphometry in electron microscopic cytology. Int. Rev. Cytol. 1969, 26:235-302.

44. Taga R, Sesso A, Pardini LC. Avaliação da homogeneidade da amostra em morfometria. Rev. Fac. Odontol. Bauru. 1998 out-dez, 6(4):57-60.

45. Pardini L.C. Estudo morfométrico da glândula submandibular do camundongo. Comparação entre sexos. (Dissertação - Mestrado). Bauru: Faculdade de Odontologia de Bauru, Universidade de São Paulo, 1985.

46. Schaefer A. The mathematical basis of stereology. Microscopion. 1970, 7(18 e 19):3-13. 
47. Moreira CR, Azevedo LR, Lauris JRP, Taga R, Damante JH. Quantitative age-related differences in human sublingual gland. Arch Oral Biol. 2006, 51:960-6. 


\section{Abstract \\ MORPHOMETRIC STUDY OF ACINAR AUTOLYSIS IN SUBLINGUAL GLANDS OF RATS: IT'S RELATION WITH INTERVAL POST MORTEM AND THE FORMALIN VOLUME POST MORTEM}

Acinar post mortem autolysis is a phenomenon that difficult the microscopic analysis in human sublingual glands. The aim of the present study is to evaluate the influence of the post mortem interval (PMI) and formalin volume (FV) in the occurrence of acinar autolysis in sublingual glands of rats. Sixty animals were used in this study. Out of them fifty animals were divided in 2 groups for PMI investigation: group I (25 animals) for morphometric quantifications and group II (25 animals) to calculate the retraction factor and the density of the glands. The groups I and II were subdivided in subgroups with 5 animals each: A and A1 (control - 0 hour), B and B1 (3 hours post mortem), C and C1 (6 hours), D and D1 (12 hours) and E and E1 (24 hours). The remaining 10 animals were used for the FV study and were divided in two groups with different volume of formalin, $2 \mathrm{~mL}$ and $20 \mathrm{~mL}$ respectively. The fixation period was 7 days. The glands were processed and stained with HE. The morphometric analysis was performed in $\mathbf{5 0}$ histological fields, selected by systematic sampling, using lens of 100x and ocular Kpl 8x containing a Zeiss II integration grid with 100 points symmetrically distributed. The volume density of intact and autolysed acini was evaluated by the morphometric method of relative volume of counting of points. There was a statiscally significant difference between volume density acinar autolysis and PMI for all group tested $(p=0,0001)$. The difference was not significant for $F V(p=$ $0,690)$. We concluded that acinar autolysis in rat sublingual glands increased significantly with the PMI, not being influenced by the FV, as tested.

Keywords: sublingual gland, autolysis, tissue fixation 